\title{
Intergovernmental Transfers and Elementary Education: Quasi-Experimental Evidence from Brazil*
}

\author{
Stephan Litschig ${ }^{\dagger}$
}

October 21, 2008

\begin{abstract}
Whether providing additional resources to local communities leads to improved public services and better outcomes more generally, given existing management capacity and incentive and accountability structures, is an unresolved yet important question for public policy. This paper uses a regression-discontinuity design to evaluate the effect of unrestricted fiscal transfers on local spending (including on education), schooling and learning in Brazil. Results show that transfers increase local public spending almost one for one with no evidence of crowding out own revenue or other revenue sources. Extra per capita transfers of 1000 Reais lead to about 0.42 additional years of elementary schooling and student literacy rates increase by about 5.6 percentage points on average. Part of this effect arises through higher teacher-student ratios in municipal elementary school systems. Results also suggest that additional resources have stronger effects in more rural and less developed parts of Brazil.
\end{abstract}

Keywords: intergovernmental grants, school finance, foreign aid effectiveness JEL: H7 I2 O15

\footnotetext{
*I am grateful to Rajeev Dehejia, Albert Fishlow, Wojciech Kopczuk, David Lee, Leigh Linden, Bentley MacLeod, Kiki Pop-Eleches, Bernard Salanié, Joseph Stiglitz, Miguel Urquiola and Till von Wachter for their comments and support throughout this project. I also received helpful comments from seminar participants at the Center for Global Development, Columbia University, FGV Rio de Janeiro, the Harris School, UC Merced, University of Montreal, Universitat Pompeu Fabra, University of Toronto, the BWPI summer school 2007 at Manchester University and the 2007 NSEA conference in St. Gallen. I acknowledge financial support from the Department of Economics, PER and ILAS at Columbia University. All remaining shortcomings are my own.

†Universitat Pompeu Fabra, Department of Economics and Business
} 


\section{Introduction}

Whether providing additional resources to local communities leads to improved public services and better outcomes more generally, given local management capacity and incentive and accountability structures, is an important yet unresolved question for public policy. In the area of public education, most existing aggregate expenditure studies find no statistically significant effects on school outcomes. ${ }^{1}$ Even if they do, causal interpretation of these results is difficult because the source of variation in resources is usually unknown and omitted variable bias is likely to be important. At the country level the question of resource effectiveness is also largely unsettled, some arguing that foreign aid promotes growth only in "good" policy environments [Burnside and Dollar 2000], others casting doubt on that claim by updating Burnside and Dollar's data set [Easterly, Levine and Roodman 2004] and still others maintaining that "short-term" aid increases growth unconditionally and only slightly more so in "good" policy environments [Clemens, Radelet and Bhavnani 2004].

The key innovation of this paper is to provide evidence on the effectiveness of general budget support interventions in improving local public services, education in particular, using a quasi-experimental approach. The source of variation in public resources stems from thresholds in a population-based revenue sharing mechanism between the federal and local governments combined with census population estimates from 1980 . These thresholds create discontinuities in federal per capita transfers to local governments from 1982 until 1990, cumulatively equal to approximately $20 \%$ of annual local GDP, which I exploit to estimate effects on local spending (including on education) and human capital accumulation using a regression-discontinuity (RD) design. ${ }^{2}$ Results show that transfers increase local public spending almost one for one with no evidence of crowding out own revenue or other revenue sources. Extra per capita transfers of 1000 Reais lead to

\footnotetext{
${ }^{1}$ See Hoxby [2000] and Hanushek [2006] for the skeptical view on resource effects in education, both in the US and in developing countries. See Krueger [2003] and Krueger and Whitmore [2001] for the view that additional education resources, class size reductions in particular, do matter in the US. See Glewwe and Kremer [2006] for a cautiously optimistic view of the micro literature for developing countries.

${ }^{2}$ See Hahn, Todd, and van der Klaauw [2001] and Lee [2007] on identification issues in RD analyses.
} 
about 0.42 additional years of elementary schooling and student literacy rates increase by about 5.6 percentage points on average. ${ }^{3}$ Part of this effect arises through higher teacher-student ratios in municipal elementary school systems. Results also suggest that additional resources have stronger effects in more rural and less developed parts of Brazil.

Given that the variation in resources occurs at the level of the total public budget, effects on schooling and literacy may arise through channels other than education spending such as through improved local housing or transportation infrastructure conditions for example. In fact, one of the advantages of expenditure decentralization is that it allows local governments to exploit context-specific potential complementarities among these interventions, which a central government planning ministry might not even be aware of. Results presented here are thus best interpreted as "public service quality" effects, rather than "school quality" effects. The distinction is worth mentioning not just for this study but for most existing aggregate studies on education since these typically use measures of school resources that are likely to capture other dimensions of the public service environment as well. ${ }^{4}$ The advantage of the analysis presented here is that the source of variation in public service quality is known and as a result there is less concern about omitted variable bias. ${ }^{5}$

The positive effects of public service quality on educational attainment reported here are qualitatively consistent with both micro (school or classroom level) and aggregate (state or district level) studies in the US and in developing countries. ${ }^{6}$ The positive effects on educational achievement (literacy) are also in line with most of the estimates in the aggregate literature evaluating effects on test scores summarized by Hanushek [2006].

\footnotetext{
${ }^{3}$ During 2005 the average Real $/ \$$ exchange rate was 2.4348 . The Real $/ \$$ purchasing power parity exchange rate was about 1.4 [World Bank 2008].

${ }^{4}$ Behrman and Birdsall [1983] and Birdsall [1985] use average schooling of teachers and average teacher income across geographical areas in Brazil. Card and Krueger [1992] use teacher-student ratios, average teacher pay and length of the school year across states in the US.

${ }^{5}$ Omitted variables or selection could bias resource estimates upwards if resources are positively correlated with unobserved characteristics that also positively affect student performance such as community income or parents' educational attainment. Selection could bias resource estimates downwards if resources were allocated in compensatory manner to disadvantaged communities.

${ }^{6}$ For aggregate evidence see Card and Krueger [1992], Heckman, Layne-Farrar, Todd [1996] for the US and Duflo [2001] for Indonesia. For micro studies see Chin [2005] and Banerjee, Jacob, Kremer, Lanjouw and Lanjouw [2000] for evidence on India. Case and Deaton [1999] and Glewwe, Kremer and Moulin [2007] provide evidence for Africa.
} 
In constrast to most of the studies summarized by Hanushek, the results presented here are comfortably signficant at conventional levels, however. Micro studies on school quality and learning based on randomized and natural experiments tend to give mixed results. ${ }^{7}$

It is worth emphasizing that the estimates reported here are average treatment effects for the subpopulation of counties with populations at or near the first three cutoffs. Because I find similar effects at these cutoffs, however, results are likely to generalize to small local communities in Brazil more generally. Because resource effects are estimated across Brazil, not just in a given locality, the external validity of results presented here is relatively high compared to micro studies at the school or classroom level which are for the most part implemented in logistically convenient regions [Duflo, Glennerster and Kremer, 2007]. External validity is also relatively high because program beneficiaries were not aware of the experiment and thus could not have reacted to it. Similarly, local and central government managers had no incentives to make the intervention look favorable in order to increase the chances of scaling up for example [Hoxby 2000]. A final advantage of the aggregate estimates presented here is that they may capture potential spillover and general equilibrium effects which micro studies inherently cannot estimate [Heckman, Lochner and Taber 1998].

In addition to contributing to the debate on (school) resource effectiveness in developing countries, this paper is related to the literature on intergovernmental grants and local spending. One of the main results in this literature is the so-called flypaper effect, the empirical observation that intergovernmental transfers appear to increase local spending by much more than an equivalent increase in local income. While there is a vast literature on this subject for the US, much less is known about flypaper effects in developing countries and most of the existing empirical work is plagued by endogeneity problems of various kinds. ${ }^{8}$ Some of these concerns have been addressed by Knight [2002], who

\footnotetext{
${ }^{7}$ See Glewwe and Kremer [2006] for a survey of the voluminous micro evidence for developing countries. See Muralidharan and Sundararaman [2006] and Duflo, Dupas and Kremer [2007] for recent evidence based on large field experiments in India and Africa, respectively. See Krueger and Whitmore [2001] and Krueger [2003] for results from Project Star, a randomized class-size reduction experiment in the state of Tennessee. See Hoxby [2000] and Hanushek [2006] for a discussion of some of the problems with the implementation of Project Star.

${ }^{8}$ See Hines and Thaler [1996] and Worthington and Dollery [1999] for a review of this literature and
} 
uses an IV approach to show that controlling for local political preferences, which may increase both spending and received transfers, there is no flypaper effect. In a similar vein, Gordon [2004] uses variation in transfers induced by the release of census data and finds that the flypaper effect exists but disappears over time as school districts reduce their own revenue effort and state governments adjust their transfers in response to federal transfers. Results from the natural experiment considered here suggest that the flypaper effect is real phenomenon among Brazilian local governments and not purely the result of mis-specification and omitted variable bias or failure to examine effects over time.

This paper is also related to the macro development literature on the effectiveness of international aid which attempts to ascertain under what circumstances international government transfers affect economic growth. Like the flypaper and school resource effectiveness literature discussed above, empirical work on aid effectiveness is struggling with endogeneity problems. ${ }^{9}$ The results on resource effectiveness considered here suggest that the first two steps in the causal mechanism between aid and growth (grants to spending and spending to schooling and learning) are working properly in the Brazilian context. Results also suggest that targeting aid to poor communities is likely to yield higher returns than providing extra resources to richer communities.

In order to assess the internal validity of the results presented in this paper I run a series of tests and robustness checks. First, I verify whether counties in the marginal (to the threshold) treatment and comparison groups were ex ante comparable ${ }^{10}$, by testing for discontinuities in pre-treatment covariates at the thresholds and find no significant differences in potential confounding factors such as county own and total revenue, education spending, income per capita, poverty, urbanization, elementary school enrollment, schooling and infant mortality. Second, I find no evidence of manipulation of county population figures in $1980 .{ }^{11}$ Third, I show that results on local (education) spending, related problems in empirical work.

${ }^{9}$ In particular, one suspects that aid donors would base their funding decision at least in part on a country's past and/or expected performance, either rewarding countries that are performing well or assisting those that do particularly badly or both at different points in time and depending on the donor. Variation in aid funding is thus unlikely to be exogenous and instrumenting for aid is notoriously difficult.

${ }^{10}$ Counties in the marginal treatment (comparison) group are those with population estimates in the interval $c, c+\varepsilon(c-\varepsilon, c)$, where $c$ is a cutoff and $\varepsilon$ some small number relative to county population.

${ }^{11}$ In a related project I document manipulation of 1991 population estimates that were made prior 
schooling and literacy are robust to both the inclusion of pre-treatment covariates in the outcome equations and to the choice of bandwidth for local linear estimation. ${ }^{12}$ Fourth, I provide suggestive evidence that the schooling and literacy gains stem at least partly from improvements in the local eduation sector rather than being driven entirely by selective migration since estimates are quantitatively close when the sample is restricted to individuals who were born in a given county and never moved away. Finally, I estimate the effect of transfers on schooling for cohorts that were out of schooling age (individuals 29 years and older in 1991) when the differential transfers started in 1982 and find no significant effects from this placebo experiment.

The remainder of the paper is organized as follows: section 2 provides institutional background on the revenue sharing mechanism, describes the data and presents a framework for thinking about the causal effects estimated in this paper. Section 2 also gives an brief overview of local government involvement in the provision of elementary education and existing educational attainment levels at the beginning of the 1980's. Section 3 presents the identification and estimation approach. Section 4 provides internal validity checks and section 5 presents estimation results. Section 6 concludes with a discussion of extensions.

\section{Background}

\subsection{Mechanics of revenue sharing in Brazil}

Local governments manage a substantial amount of public resources in Brazil. In 2002, local governments were in charge of $16,6 \%$ of total public revenue [BNDES, 2003], spending mostly on elementary education, preventive health care, public housing and local public transportation. This spending is to a large extent financed by intergovernmental transfers. For counties with a population of up to 50,000, federal and state government

to the census of 1991 and attempt to estimate whether this manipulation can be accounted for using determinants of the political patronage literature.

${ }^{12}$ See Hahn, Todd and Van der Klaauw [2001], Porter [2003] and Imbens and Lemieux [2007] for details on local linear estimation in regression discontinuity designs. See Miller and Ludwig [2007] for a recent $\mathrm{RD}$ application that is similar in both content and methodology to the analysis presented here. 
transfers made up $80 \%$ of local revenue in 2001 . The most important among these transfers is the Fundo de Participacao dos Municípios (FPM), an unconditional revenue sharing grant which by itself contributes about $45 \%$ of revenue for small to medium sized local governments [BNDES, 2002].

FPM revenue sharing grants are constitutionally mandated federal government transfers to local governments. ${ }^{13}$ The FPM is funded by federal income tax and industrial products tax collections. The critical feature of the revenue-sharing mechanism for the purposes of this analysis is that Decree 1881/81 stipulates that transfer amounts depend on county population in a discontinuous fashion. More specifically, based on county population estimates, $p o p^{e}$, counties are assigned a coefficient $c=c\left(p o p^{e}\right)$ where $c($.$) is the$ step function shown in Table I. For counties with up to 10,188 inhabitants, the coefficient is 0.6 , from 10,189 to 13,584 inhabitants, the coefficient is 0.8 and so forth. The coefficient $c\left(\right.$ рор $\left.^{e}\right)$ determines the share of total FPM resources, rev, which are distributed to county $c$ in year $t$ according to the following formula:

$$
F P M_{c t}=\frac{c\left(p o p_{c}^{e}\right)}{\sum c_{c}^{e}} r e v_{t}
$$

The law thus creates discontinuities in FPM transfers at the various thresholds as shown in figure 1 using data from 1982 until 1985. The figure shows that FPM transfers jump by about 10,000,000 Reais (2005 prices) at each threshold over this period (FPM transfers are given in thousands) which amounts to about $20 \%$ of annual GDP in 1980 for counties with population in the range 8500 to 18,700 (Table II). ${ }^{14}$ It represents roughly $35 \%$ of annual GDP in the North and about $13 \%$ of annual GDP in the South for counties in this range.

The 1980 census figures on which this analysis is based were used as official population estimates starting in 1982 up to 1985. In 1985, county population estimates were updated by the national statistical agency, IBGE, using a top-down approach that ensures consistency of estimates for lower level units (counties) with the higher levels (states and

\footnotetext{
${ }^{13}$ Federal Constitution of Brazil, Art. 159 Ib.

${ }^{14}$ During 2005 the average Real/\$ exchange rate was 2.4348 .
} 
the country as a whole)[IBGE, 2002]. As a result of the 1985 update some counties were classified upwards and (few) were classified downwards relative to their 1980 classification. The 1985 update was in effect for the years 1986, 1987 and 1988. Starting in 1988, official population estimates were updated annually and some more counties were reclassified in 1989 and 1990. ${ }^{15}$ The upshot of these county population updates is that by 1991 counties that were just below a given threshold in 1982 now received the same amount of transfers as those counties that were just above the threshold in 1982. Figure 2 illustrates the evolution of FPM transfers over time for counties in the marginal (to the threshold) treatment and comparison groups.

\subsection{Data sources}

The analysis in this paper draws on multiple sources of information. Population estimates determining transfer amounts from 1982 until 1991 were taken from successive reports issued by the federal court of accounts (TCU). Data on local public budgets, including FPM transfers and local education spending, are self-reported by county officials and compiled into reports by the secretariat of economics and finance (SEF) inside the federal ministry of finance $(\mathrm{MF})$. The data from these reports were then entered into spreadsheets by Digital Divide Data using independent double entry processing. All public finance data were converted into 2005 currency units using the GDP deflator for Brazil. Data on 1980 county characteristics are based on the $25 \%$ sample of the census and have been calculated by the national statistical agency. Data on municipal elementary schools and teacher-student ratios are from the 1991 school infrastructure survey. Data on cohort specific years of schooling and literacy rates are based on the $10 \%$ and $20 \%$ samples of the 1991 census and have been calculated by the author.

Table II shows descriptive statistics for the variables used in the statistical analysis. The numbers show that FPM transfers are the most important source of revenue for the relatively small local governments considered here, amounting to about $48 \%$ on average and $66 \%$ in the North of Brazil. The table also shows that education spending accounts

\footnotetext{
${ }^{15}$ Supplementary Law ${ }^{\circ}$ 59/1988.
} 
for about $20 \%$ of local budgets, with similar shares going to housing and transportation spending. In addition, the table documents a strong difference in development indicators between the relatively developed southern part of the country (South, Southeast and Center-West regions) and the less developed northern regions (North and Northeast). The contrast between rural and urban communities is similarly striking.

\subsection{Conceptual framework}

The key innovation of this paper is to exploit quasi-random local variation in transfers induced by population thresholds to evaluate the effect of resources on local spending (including on education), schooling and learning. Given that variation in resources occurs at the level of the total public budget, effects on schooling and literacy may arise through channels other than the education budget such as through improved local housing or transportation infrastructure conditions for example. The resulting reduced form estimates may be higher or lower than those from specific education or infrastructure interventions depending on the level of complementarity of these interventions and the extent of resource leakage in the local implementation process due to bad management and corruption.

The following presents a frameworks for thinking about the causal effects estimated in this paper. Assume that both local schooling $S$ and learning $L$ in the local community depend on public spending on education $E$, mainly through class size $C$, and on transportation and housing infrastructure $I$ which in turn depend on the overall level of resources $R$ of which FPM transfers $F$ represent an important share:

$$
\begin{aligned}
& S=S(C(E(R(F))), I(R(F))) \\
& L=L(S(.), C(E(R(F))), I(R(F)))
\end{aligned}
$$

As noted earlier, most recent studies using clearly identified sources of variation investigate the effects of providing real resources to particular schools or classrooms, i.e. they evaluate the partial derivatives $S_{C}$ and $L_{C}$. In contrast, the effects estimated here 
can be thought of as $S_{F}$ and $L_{F}$ which represent total derivatives of schooling and literacy with respect to financial resource transfers, i.e. they capture effects arising through multiple spending channels, not just education spending. In particular, $S_{F}$ and $L_{F}$ both incorporate $R_{F}$, the marginal propensity to spend transfers received and $E_{R}$ and $I_{R}$, the marginal propensities to spend on education and infrastructure, respectively. Existing aggregate studies on resource effectiveness essentially evaluate $S_{E}$ and $L_{E}$, typically at the county, district or state level. Although there is a large literature on this subject, most of these studies find no statistically significant effects on school outcomes and even if they do, causal interpretation of these results is difficult because the source of variation in resources is largely unknown and omitted variable bias is likely to be important [Hanushek 2006].

The key contribution of this paper is to provide unbiased causal estimates of $R_{F}, E_{R}$, $I_{R}, S_{F}$ and $L_{F}$. All of these are of interest on their own. $S_{F}$ and $L_{F}$ are of interest to central government policymakers who need to gauge the social returns on financing local investments in social services and infrastructure, given local management capacity and incentive and accountability systems. $S_{F}$ and $L_{F}$ can also usefully be evaluated in different subsamples (below) and institutional contexts (extensions) in order to assess under what circumstances additional resources yield the highest returns. $E_{R}$ and $I_{R}$ are of interest because they reveal local preferences for public services (income expansion paths). In particular, $E_{R}$ and $I_{R}$ can be used to empirically assess the hypothesis that local governments know better what they need than the central government by testing whether counties which exhibit disproportionate increases in particular spending categories also show disproportionate changes in real outcomes along these dimensions (extensions). $R_{F}$ is also of interest on its own both from a policy and a theoretical perspective. From a policy perspective, the central government is presumably interested in knowing whether transferred resources are spent on private goods and services or whether they finance investments in education and infrastructure.

From a theoretical perspective $R_{F}$ is and interesting parameter because economic the- 
ory has relatively clear predictions regarding its sign and size. Assuming that the median voter desires both more private consumption and more consumption of public services as her income grows, standard theory would predict that at least part of the extra income should be spent on private consumption goods. The next paragraph attempts to quantify the predicted magnitude of $R_{F}$. Because of measurement error in both local public finance and GDP statistics the numbers below should probably not be taken at face value. They are nevertheless likely to be indicative of relative orders of magnitude.

Given that local governments' average propensity to spend on public services out of local GDP is about 3\% on average (Table II) and assuming that the marginal propensity to spend is somewhat similar, one would expect about $3 \%$ of every additional dollar (cruzeiro) to be spent by local governments and the remaining $97 \%$ by local residents, i.e. $R_{F} \approx 0.03$. Because the marginal cost of funds received from the federal government is likely to be much lower than the marginal cost of own revenue collection due to tax base erosion and higher administrative costs, $R_{F}$ would predictably be higher than 0.03 . A reasonable upper bound for predicted $R_{F}$ might be about 0.5 since total revenue and spending represent $50 \%$ of local GDP on average for the small local governments considered here. The results presented below suggest, however, that about $100 \%$ of extra transfers are spent by local governments and $0 \%$ by local residents, which is hard to reconcile with median voter theory. Figure 4 illustrates both the predicted allocation under a relaxed budget constraint at point $\mathrm{B}$ and the actual allocation estimated in this paper at point $\mathrm{C}$. The next section gives some detail on locally provided elementary education in Brazil around 1980.

\subsection{The role of Brazilian local governments in fundamental education}

Total public elementary or fundamental education spending by all three levels of government in Brazil was about 1\% of GDP in 1983, a relatively low figure compared to other countries in Latin America at the time. ${ }^{16}$ Public provision of elementary education in Brazil is for the most part a joint responsibility of state and local governments while

\footnotetext{
${ }^{16}$ Data references in this section are extracted from World Bank [1985].
} 
the federal government is primarily involved in financing and standard setting. Of total public elementary education spending, local governments accounted for about $26 \%$, while state governments accounted for about $65 \%$ with the remainder accounted for by the federal government. About 21\% of local government budgets were devoted to education, with the bulk (72\%) going to fundamental education (grades 1-8) and the remainder to intermediary education (grades 9-12).

In 1980, 55\% of elementary school students were enrolled in state administered schools, $31 \%$ in municipio schools and the remaining $14 \%$ in private schools. In rural areas, however, the proportion of students in schools managed by local governments was $74 \%$ while the proportions for state-run and private schools were $24 \%$ and $2 \%$ respectively. elementary school is compulsory for 7 to 14 year olds, but less than $14 \%$ of an age cohort in 1980 completed the 8 grades of compulsory schooling in 8 years. The average number of completed grades after 8 years in school was about 5 . Individuals are eligible to attend regular elementary school until the age of 18 and regular intermediary school until the age of 21. Beyond these age limits individuals have to enroll in special education classes.

\section{$3 \quad$ Identification and estimation approach}

The basic intuition for the regression-discontinuity (RD) approach used in this paper is that in the absence of program manipulation, observations close to the treatmentdetermining population cutoff are likely to exhibit similar mean outcomes both with and without additional resources. Counties just above the cutoff should thus provide valid counterfactual outcomes for those counties just below the cutoff which did not receive additional transfers. Because there are typically not enough observations in a local neighborhood of the threshold, RD analysis makes use of observations further away from the threshold which requires assumptions on the relationship between the treatmentdetermining variable and the mean outcome of interest [HTV 2001, Van der Klaauw 2002].

In the $\mathrm{RD}$ application presented here there are enough counties close to the first three 
population cutoffs to reject the null hypothesis of zero effect of transfers on outcomes in the pooled discontinuity sample (using a bandwidth of $+/-400$ people around the threshold) alone without using observations further away from the thresholds. In what follows I first present the estimation approach using an extended population support for the first 6 thresholds shown in figure 1 and then the approach using the discontinuity samples across the first 3 thresholds both individually and pooled. The reason for pooling only across the first 3 thresholds is that for larger counties the increase in FPM transfers at subsequent cutoffs is too small to affect their overall budget and hence there is no "first stage" in terms of overall resources available for the county as further detailed below.

More formally, let $Y_{c s}$ denote the outcome of interest (local total revenue and total spending, local education spending, schooling or literacy) and $p o p_{c s}$ the population in county $c$ state $s, \gamma$ the causal parameters of interest, $f\left(\right.$ pop $\left._{c s}\right)$ the control function, $T$ a particular threshold and $W=1\left[p_{p s}>T\right]$ the indicator function for treatment (additional resources). The regression model is as follows:

$$
Y_{c s}=\alpha_{0}+\gamma 1\left[\text { pop }_{c s}>T\right]+f\left(\text { pop }_{c s}\right)+c_{s}+u_{c s}
$$

Since $p o p_{c s}$ is the only systematic determinant of treatment status, a correctly specified function $f($.$) yields consistent estimates of the treatment effect. In particular, if E[Y$ $\mid W=1, p o p]$ and $E[Y \mid W=0, p o p]$ are continous in population then $\gamma=\lim _{p o p \downarrow T} E[Y \mid$ pop $]-\lim _{p o p \uparrow T} E[Y \mid$ pop $]$ identifies the average treatment effect at the threshold. ${ }^{17}$ Strictly speaking, the treatment effects presented in this paper apply only to counties with population levels at the respective cutoffs. But because results are quantitatively similar across the first 3 thresholds, as shown in detail below, it seems likely that the resource effects presented here generalize at least to the subpopulation of small local governments in Brazil.

Because the specification of the control function $f\left(p_{p o} p_{c s}\right)$ is particularly important when using observations further away from the threshold I present estimation results

\footnotetext{
${ }^{17}$ See Lee [2007] for an alternative interpretation of the average treatment effect identified in an RD analysis.
} 
from linear, quadratic and cubic polynomial specifications, allowing for differential slope and curvature around the first 6 thresholds. Letting $p$ denote the order of the polynomial in the control function, $s_{k}$ a set of integers that bound and partition the population support and $\mathbf{z}_{c s}$ a set of pre-treatment covariates, the full specification is as follows:

$$
\begin{gathered}
Y_{c s}=\sum_{k=1}^{6} \gamma_{k} 1\left[\text { pop }_{c s}>T_{k}\right]+\sum_{k=1}^{p} \alpha_{0 k} \text { pop }_{c s}^{k}+\sum_{k=1}^{p} \alpha_{1 k}\left(\text { pop }_{c s}-T_{1}\right)^{k} 1\left[\text { pop }_{c s}>T_{1}\right] \\
+\sum_{k=1}^{p} \alpha_{2 k}\left(\text { pop }_{c s}-T_{2}\right)^{k} 1\left[\text { pop }_{c s}>T_{2}\right]+\sum_{k=1}^{p} \alpha_{3 k}\left(\text { pop }_{c s}-T_{3}\right)^{k} 1\left[\text { pop }_{c s}>T_{3}\right] \\
+\sum_{k=1}^{p} \alpha_{4 k}\left(\text { pop }_{c s}-T_{4}\right)^{k} 1\left[\text { pop }_{c s}>T_{4}\right]+\sum_{k=1}^{p} \alpha_{5 k}\left(\text { pop }_{c s}-T_{5}\right)^{k} 1\left[p o p_{c s}>T_{5}\right] \\
+\sum_{k=1}^{p} \alpha_{6 k}\left(\text { pop }_{c s}-T_{6}\right)^{k} 1\left[\text { pop }_{c s}>T_{6}\right]+\sum_{k=1}^{6} \beta_{k} 1\left[s_{k-1}<\text { op }_{c s} \leq s_{k}\right] \\
+\mathbf{z}_{c s}+a_{s}+u_{c s}
\end{gathered}
$$

Following Hahn, Todd and Van der Klaauw [2001], Porter [2003] and Imbens and Lemieux [2007], I also use local linear regression in the discontinuity samples. As mentioned above, the advantage of using observations around the cutoffs is that they are ex ante more comparable than observations further away from the cutoffs. Local linear estimation allows for (differential) slopes of the regression function in a neighborhood of the cutoff. This is particularly important in the present application because per capita transfers are declining as population approaches the threshold from below and again declining after the threshold. Assuming that a similar pattern characterizes outcomes as a function of population, a simple comparison of means for counties above and below the cutoff would provide downward biased estimates of the treatment effect.

In order to gain statistical power in the discontinuity sample, I also pool counties across the first three thresholds $(10188,13584$ and 16980). For the pooled analysis I rescale population to equal 0 at the respective thresholds within each of the first three 
segments and use the scaled variable $x_{c s}$ for estimation purposes:

$$
\begin{array}{r}
x_{c s}=\text { pop }_{c s}-10188 \text { if } 5000<\text { pop }_{c s} \leq 11800 \\
\operatorname{pop}_{c s}-13564 \text { if } 11800<\text { pop }_{c s} \leq 15100 \\
\operatorname{pop}_{c s}-16980 \text { if } 15100<\text { pop }_{c s} \leq 23772
\end{array}
$$

The pooled estimation equation is as follows:

$$
\begin{gathered}
Y_{c s}=\gamma 1\left[x_{c s}>0\right]+\alpha_{1} x_{c s}+\alpha_{2} x_{c s} 1\left[x_{c s}>0\right] \\
+\alpha_{3} x_{c s} 1\left[s_{1}<p o p_{c s} \leq s_{2}\right]+\alpha_{4} x_{c s} 1\left[s_{1}<p o p_{c s} \leq s_{2}\right] 1\left[x_{c s}>0\right] \\
+\alpha_{5} x_{c s} 1\left[s_{2}<p o p_{c s} \leq s_{3}\right]+\alpha_{6} x_{c s} 1\left[s_{2}<p o p_{c s} \leq s_{3}\right] 1\left[x_{c s}>0\right] \\
+\sum_{k=1}^{3} \beta_{k} 1\left[s_{k-1}<p o p_{c s} \leq s_{k}\right]+\mathbf{z}_{c s}+a_{s}+u_{c s}
\end{gathered}
$$

The average conditional treatment effect is given by $\gamma=\lim _{\Delta \downarrow 0} E[Y \mid x=\Delta]-E[Y \mid$ $x=0]$. I also use the above specification segment by segment to estimate effects at the first three thresholds individually. I follow the suggestions by Imbens and Lemieux [2007] and use a rectangular kernel and standard least square theory for inference. Both the pooled treatment effect and effects at individual thresholds are estimated using observations within successively larger bandwidths in order to assess robustness of the results.

\section{Internal validity checks}

A primary concern in any $\mathrm{RD}$ analysis is manipulation of the variable assigning treatment, i.e. county population in the present application. Local mayors or other actors clearly had an incentive to manipulate population figures in order to get more resources from the federal government. Such manipulation would cast serious doubts on the internal validity of the design since counties obtaining extra funds would presumably be different in dimensions that are likely to be correlated with outcomes, e.g. they might be better managed overall.

A key feature of the variation in resources analyzed in this paper is that it is highly 
unlikely to be driven by selection. While the general treatment assignment rule based on population estimates was known for more than a decade prior to 1980, actual thresholds, as specified in Decree no. 1881/81, were updated after the 1980 census results were known. Even if local mayors were attempting to manipulate particular county population estimates to reach the next higher transfer bracket, some would have inevitably landed above and some below the cutoff, making treatment assignment locally random. ${ }^{18}$ Consistent with local random assignment is the fact that the distribution of population estimates exhibits no discontinuities at the thresholds determining transfer brackets. ${ }^{19}$ Neither is it likely that central government administrators adjusted the thresholds in a way that benefited their local political allies. Manipulating thresholds is simply too blunt an instrument for patronage politics or corruption. Another potential concern is that other government policies are also related to the cutoffs specified in Decree no. 1881/81 but to my knowledge this is not the case.

The next section will provide evidence pointing to a high internal validity of the RD approach in the present setting by showing that the results on local (education) spending, schooling and literacy are robust to the inclusion of relevant pre-treatment covariates such as county income per capita, average years of schooling for individuals 25 years and older, poverty headcount ratio, illiterate percentage of over 15 year olds, infant mortality, enrollment of 7 to 14 year olds and percent of population living in urban areas. Inclusion of these potential confounding factors does not significantly alter treatment effect estimates in the discontinuity sample, suggesting that none of these variables are strongly correlated with both treatment status and outcomes. Consistent with this result is that I find no evidence of systematic statistically or economically significant differences when I test for discontinuities in these variables directly (results not shown).

Another key testable implication of local random assignment is the continuity of the population density function at the various thresholds. Discontinuous distributions suggest that sorting around the thresholds is an important feature of the data which is likely to

\footnotetext{
${ }^{18}$ See Lee [2007] for further discussion of this point.

${ }^{19}$ See McCrary [2007] for discussion and a formal test for manipulation of the treatment-determining variable in $\mathrm{RD}$ designs.
} 
bias treatment impacts. Figures 5 and 6 plot histograms for the full support of population and the lefthand side of the distribution, respectively. Visual inspection reveals no glaring discontinuities for the majority of thresholds except for a somewhat curious bump to the right of the third threshold.

The next two figures report discontinuity tests for pre-treatment county total revenue (figure 7) and education spending (figure 8) in 1981. Neither visual inspection nor estimation results suggest that marginal treatment group counties were systematically different in terms of overall resources and education spending patterns from counties in the marginal comparison group prior to 1981. Similar results hold for 1981 current transfers, which include as main components FPM and state value-added transfers (results not shown). 1981 public finance reports do not disaggregate current transfers into FPM transfers and other categories, but FPM transfers represent the bulk of current transfers and any discontinuities in predetermined FPM transfers should therefore show up in current transfers for 1981. Estimates for 1981 current transfers are close across specifications and give no evidence of systematic sorting across any of the thresholds.

\section{Estimation results}

This section starts out by demonstrating that FPM transfers were indeed allocated according to the step function stipulated by Decree 1881/81 and then provides estimates of the flypaper effect, $R_{F}$, and income effects on local government spending categories $E_{R}$ and $I_{R}$. The second part presents estimates of the effect of budgetary transfers on school resources $C_{F}$ and school outcomes $S_{F}$ and $L_{F}$. The third subsection shows that additional resources seem to have stronger effects in more rural and less developed parts of Brazil. Each subsection contains a graphical analysis, based on a scatterplot of residuals from an auxiliary regression of the outcome variable on state and segment effects against population as well as estimation results and discussion. ${ }^{20}$ The section concludes by providing

\footnotetext{
${ }^{20}$ Although the relationship between population and FPM transfers is in principle deterministic, there is measurement error in the reporting process and so I present estimation results in addition to the graphical analysis.
} 
easily interpretable IV estimates of schooling and literacy gains for the north and south as well as rural and urban areas of Brazil.

\subsection{Flypaper effect and income effects on spending categories}

Figure 9 displays the scatterplot of residual cumulative FPM per capita transfers over the period 1982-1985 against population across the first 6 thresholds. Each dot represents a local average in a bin-width of 100 and the solid line represents the estimated linear regression function. The figure shows clear discontinuities at the first three cutoffs and somewhat less clear jumps for the remaining thresholds. The corresponding table confirms the visual impression. Per capita FPM transfers jump by about 33 to $38 \%$ at the first threshold and decline monotonically for the next two cutoffs. This pattern is as one would expect since the absolute increase in FPM transfers is constant while population is higher at each subsequent threshold.

There is somewhat weaker evidence that FPM transfers jump at the subsequent 3 cutoffs depending on the specification. Overall, the scatterplot and estimation results suggest a strong first stage both in terms of size and significance across the first 3 cutoffs and a weaker first stage for the subsequent cutoffs. It is also interesting to note that the inclusion of pretreatment variables does not significantly alter point estimates or standard errors, suggesting that the revenue-sharing rule is indeed allocating funds to counties in a quasi-random fashion.

Figure 10 displays the scatterplot of residual cumulative total revenue per capita over the period 1982-1985 against population. The figure shows clear jumps at the first 3 cutoffs as well as at the 6th cutoff. The table reveals that the jumps in total revenue amount to 15 to $22 \%$, a magnitude consistent with the fact that FPM transfers represent about $50 \%$ of total revenue for the small counties considered here. Figures 12 and 13 show that over the period 1982-1985, there is no systematic evidence of FPM transfers crowding out own revenue or other revenue streams, which are composed of other federal and state government transfers. Together, these results suggest that total revenue increased one for 
one with FPM transfers.

Figure 10 and the associated table also show that for larger counties the increase in FPM transfers is too small to affect their overall budget and hence there is no "first stage" in terms of overall resources. It is for this reason that the discussion on schooling and literacy further below is focused on the first three cutoffs. A final point worth noting is that pre-treatment average levels of schooling, income per capita and the poverty headcount ratio are significant predictors of county per capita revenue thus lowering standard errors. Pretreatment covariates also seem to be weakly related to the treatment indicators although the change in point estimates for the various $\hat{\gamma}$ is small. As further discussed below, the fact that point estimates do change somewhat is not particularly worrisome because assignment to treatment is only random for counties close to the cutoff. In the discontinuity samples used below, there is very little change in parameter estimates when pre-treatment variables are included in the outcome equation.

Figures 14 and 15 present results for cumulative total spending and education spending respectively. The main result of figure 14 and the table below is that total spending increases by an almost identical percentage as total revenue. Because small local governments were essentially running balanced budgets at the time, this implies that total spending increased almost one for one with total revenue suggesting the existence of a strong flypaper effect at work among Brazilian local governments. As noted above, given that local governments spend about $50 \%$ of local GDP on public services and assuming that the marginal propensity to spend is somewhat similar, the fact that $100 \%$ of extra transfers are spent by local governments and $0 \%$ by local residents is a rather striking result.

Because the relatively small local governments considered here collect only about $6 \%$ of total revenue from their own residents (maybe as a result of generous federal transfers), one might argue that they have only little room to give tax reductions. In order to assess this possibility I split the sample according to median own revenue collection in 1981 and examine the effect of extra federal funds on subsequent own revenue collection in these 
two samples. In both groups there is no evidence of a systematic response of own revenue collection to extra transfers (results not shown).

At any rate, however, even in the complete absence of own revenue collection, assuming that both public services and private consumption and normal goods, basic median voter theory suggests that at least part of the extra funds received from the federal government should be transferred directly to local residents for private spending. In other words, even if local governments were not collecting any revenue from local residents, and assuming that the median voter desires both more private consumption and more consumption of public services as her income grows, median voter theory would predict that at least part of the extra income should be spent on private consumption goods.

Unfortunately, the existing breakdown of expenditure categories does not distinguish a separate expenditure category for direct transfers to individuals and so I was unable to investigate this possibility further. This also means that transfers might have effectively been spent by local residents although they show up as public spending under various categories. While this is certainly a possibility, I regard it as highly unlikely that the flypaper effect reported here is merely the result of an accounting illusion.

In sum, results suggest that median voter theory does not provide an accurate description of the local political process and that the flypaper effect is real phenomenon among Brazilian local governments, not the result of mis-specification and omitted variable bias or failure to examine effects over time. In further work I intend to examine whether institutional factors, such as participatory budgeting processes, might dampen the flypaper effect on the theory that in such environments policy choices should more accurately reflect the preferences of the local population.

The next set of figures and estimates document income effects on main local expenditure categories. Reduced form estimates for per capita education spending across the first three cutoffs (figure 15) are statistically significant at conventional levels and are centered slightly above $20 \% .^{21}$ Figures 16,17 and 18 show results for transportation, housing and administration expenditure, which Iare the other three main expenditure

\footnotetext{
${ }^{21}$ Unfortunately, data on the composition of local spending for the remainder of the decade do not exist.
} 
functions at the local level, respectively. Although these results tend to be less significant from a statistical point of view, the point estimates suggest that the extra FPM transfers led to roughly proportional increases in transportation and housing expenditures and a somewhat smaller increase in general administrative spending.

\subsection{Effects on real school resources and outcomes}

Having established that counties in the marginal treatment group spent about $15 \%$ more overall and about $20 \%$ more on education, transportation and housing than counties in the marginal comparison group just below the cutoffs, the remainder of this section proceeds to document the effects of this extra spending on real school resources such as primary school teacher-student ratios and municipal schools and finally on students' average completed years of schooling and literacy rates.

Figures 19 and 20 show effects on primary school teacher-student ratios and the number of elementary municipal schools respectively. I refer to primary school teachers as those working in grades 1-4 as opposed to grades 5-8. Elementary schools are used for both grade ranges. The tables present results for the first three cutoffs individually as well as pooled results across the first two and first three thresholds. Estimates are reasonably close across thresholds and suggest that the transfers led to an increase in the teacherstudent ratio of about .01 to .02 which compares to an average teacher-student ratio in the marginal comparison group of about .054 and amounts to 0.5 to 1 standard deviations. Results on municipal elementary schools on the other hand show no clear patterns and are imprecisely estimated, suggesting that transfers financed mostly more labor input as opposed to school infrastructure.

Figures 21 and 22 present reduced form estimates on average number of completed grades (years of schooling) for individuals 19 to 28 years and 9 to 18 years of age in 1991 respectively. The 9 to 18 years age group was still of regular elementary school eligibility age in 1991, while the 19 to 28 age group was beyond regular elementary school eligibility age in 1991 (for the 19 year olds) and just within regular intermediary school eligibility 
age in 1982 (for the 28 year olds). One would expect the younger age group to exhibit a smaller treatment effect because most of them had not completed elementary school in 1991 while the older group likely completed elementary and even intermediary education by 1991.

Both the scatterplots and estimation tables show that the data are consistent with this intuition. Estimates of treatment effects at individual thresholds show similar magnitudes across specifications but are relatively noisy. The pooled point estimates suggest that the younger cohort experienced about 0.15 years of additional schooling on average as a result of higher spending. Corresponding results for the older cohort suggest a schooling differential of about 0.3 years on average. Pooled estimates are mostly significantly different from zero even within a relatively small neighborhood of $+/-3 \%$ of the respective thresholds. $^{22}$

Consistent with random assignment in the discontinuity sample, the inclusion of rather detailed pre-treatment county characteristics on income distribution and education level of the population increases precision of the point estimates but leaves their magnitudes relatively unchanged. Given that average years of schooling in marginal comparison group counties for the 19-28 aged cohort in 1991 was about 4.3 years with a standard deviation of 1.45 years, the schooling gains amount to about $7 \%$ or about 0.2 standard deviations. For the younger cohort, the marginal comparison group years of schooling were 2.7 years with a standard deviation of 1.08 years. The 0.15 schooling gain thus amounts to about $6 \%$ or 0.14 standard deviations. Figure 25 plots treatment effect estimates from a cubic specification using the full population support against age. While most of the age-specific estimates are statistically insignificant, the estimated age profile is generally rising until the age of 19, about constant until the age of 28 and oscillating around 0 beyond that age.

Figures 23 and 24 suggest that students not only completed more grades in counties that received extra funds but also learned more. For the younger cohort these estimates

\footnotetext{
${ }^{22}$ Estimates for individuals who never left their county of birth are quantitatively similar to those presented here.
} 
suggest an increase in the likelihood of being able to read and write of about 3 percentage points. For the older cohort the corresponding effects are about 4 to 5 percentage points on average, compared to an average literacy rate of about $76 \%$ in the marginal comparison group. The literacy gains represent about .26 standard deviations of literacy skills in the marginal comparison group.

I also estimate the schooling and literacy regressions restricted to individuals who were born in a given county and never moved away (tables not shown). These results are quantitatively close to those from the unrestricted sample and thus provide suggestive evidence that the schooling and literacy gains stem at least partly from improvements in the local eduation sector rather than being driven entirely by selective migration. The results are only suggestive, however, because there could be selective attrition among nonmigrants across treatment and comparison communities. In particular, more educated individuals might be more likely to stay in the county in response to improvements in overall local service quality not necessarily related to the education sector. In the following subsection I show that additional resources have stronger effects in more rural and less developed parts of Brazil.

\subsection{Heterogeneous effects}

The North of Brazil is generally less developed than the South (see Table II). Assuming decreasing marginal productivity in the provision of education, one would expect that additional resources go further in the less educated northern parts of the country, all else equal. Of course all else might not be equal, in particular, governance could be generally worse in the North and thus extra resources received might not be spent as productively as in the South.

Table III shows effects on the number of municipal elementary schools and primary school teacher-student ratios in northern and southern parts of Brazil. Although the effects on school establishments are not precisely estimated, it is interesting to note that they tend to be consistently positive in the North and negative for counties in the South. 
Primary school teacher-student ratios tend to be positive and are statistically significant at conventional levels, especially in the South.

Table IV shows that the average schooling and literacy gains reported earlier are for the most part accounted for by gains in the northern part of the country. The conservative estimates put the schooling gains at about 0.4 to 0.5 years. Because the schooling gains also include estimates above 1 additional year of schooling these results should probably be viewed with caution. Literacy gains on the other hand are more consistently estimated across specifications and are about two to three times as large in the North as in the South. These regional differences in literacy and schooling gains are statistically significant at the $10 \%$ level. $^{23}$

Tables V and VI examine whether the notion that extra funds have larger effects in less developed areas holds true not just between the northern and southern parts of Brazil but also across rural and urban areas as distinguished by the median percentage of urban residents in 1980. Table V shows that the effects on school establishments are again not precisely estimated but that they also tend to be consistently positive in the more rural and negative for urban counties. Primary school teacher-student ratios tend to be positive and statistically significant in rural areas with no real difference in urban areas although the differential effect is not statistically significant. ${ }^{24}$

Table VI suggests that almost the entire schooling gains seem to come from rural counties (an additional .5 year of schooling) with smaller and statistically insignificant effects in urban counties. The literacy gains are more evenly spread although they too are concentrated among rural counties and somewhat smaller in urban counties. ${ }^{25}$ Since rural counties also tend to be poorer, less educated and more generally less developed (Table II), these results provide suggestive evidence that resources generally matter even more

\footnotetext{
${ }^{23}$ In particular, the coefficients and standard errors on the interaction of the treatment indicator with the region indicator ( 1 for South) in the pooled sample for schooling and literacy are, respectively: -.198 (.106) and -.019 (.011).

${ }^{24}$ The coefficient and standard error on the interaction of the treatment indicator with the urban indicator (1 for \% urban residents in 1980>24.8) in the pooled sample for the primary school teacherstudent ratio are -.003 (.004).

${ }^{25}$ The coefficients (standard errors) on the interaction of the treatment indicator with the urban indicator (1 for \% urban residents in 1980>24.8) in the pooled sample for schooling and literacy are, respectively: -.185 (.106) and -.005 (.011).
} 
in resource-poor environments than they do in relatively more developed areas. ${ }^{26}$

An alternative explanation for these effects is that poor communities have stronger preferences for education than richer communities and hence spent a higher proportion of extra funds on education. A direct test of this alternative view is to examine the share of education expenditure in total spending subsequent to the increase in funding in poor vs. rich areas. Unfortunately, however, existing expenditure data do not allow such a disaggregation between 1983 and 1989. When I test for differential effects on education expenditure shares using data from 1982 and 1983 I find no significant effects (results not shown), suggesting that stronger preferences for education in poor communities are not the driving force behind the higher schooling and literacy gains they exhibit.

The schooling and literacy gains reported here should be viewed as average causal effects of extra cumulative per capita transfers over the period 1982-1990. Table VII shows the results of instrumental variable estimations where the treatment indicators for the various thresholds are used as instruments for cumulative per capita transfers from 1982 to 1990 in the schooling and literacy equations. These IV estimates are numerically equivalent to the ratio of average differences in outcomes to average differences in cumulative transfers at the cutoffs (Wald estimates). ${ }^{27}$

Panel A shows that the first stage estimates pooled across the first three cutoffs are sligthtly larger than the pooled estimates across the first two thresholds, which makes sense given that per capita transfers are declining with population. These estimates also suggest that per capita transfers at the cutoffs increased more in the North than in the South and more in rural than in urban counties, which is surprising since the FPM formula did not differ across states at the time. Again the discrepancy might simply reflect a higher density of very small counties (around the first cutoff) in the North and rural areas compared to the South and urban areas. The IV estimates for schooling and literacy are reasonably close for both pooled specifications and suggest that.cohorts in the treatment group acquired an additional .42 years of schooling per 1000 Reais transferred per capita.

\footnotetext{
${ }^{26} \mathrm{I}$ also break the sample into high vs. low education and low vs. high initial poverty counties and find quantitatively similar results.

${ }_{27}$ In the tables this is not always the case because of missing data on FPM transfers.
} 
Literacy rates increased by about 5.6 percentage points on average. Results again suggest significantly larger schooling and literacy gains in the North of Brazil compared to the South and somewhat larger schooling gains in rural vs urban counties.

Before concluding, the following provides a rough calculation of the marginal cost of schooling implied by these estimates. IV results suggest that additional per capita transfers of $\$ 714$ buy about 0.42 additional years of schooling, adjusting for purchasing power differences. ${ }^{28}$ Assuming that about $20 \%$ of these funds are spent on education (average and marginal propensities are roughly the same as shown earlier) and assuming further that about $40 \%$ of residents used school services at some point during the 1980's, marginal education spending per student was about $\$ 714^{*} 0.2^{*} 2.5=\$ 355$. The implied marginal cost of an additional year of schooling is thus about $\$ 850$. This compares to annual education expenditures per student in 1982 of about $\$ 1200$. For rural counties the implied marginal cost of schooling is about $\$ 620$ compared to annual per student expenditures of $\$ 1000$. While these are clearly rough estimates, the order of magnitude of the estimated marginal cost of schooling seems plausible.

\section{Conclusion}

Results presented in this paper suggest that unrestricted fiscal transfers to local communities in Brazil lead to an improvement of local public service quality and have positive effects on educational outcomes. At least part of these effects arise through higher teacher-student ratios in municipal elementary school systems. The first two steps in the causal mechanism between resource transfers and economic growth (grants to spending and spending to schooling and learning) thus seem to be working properly in Brazil. Results further suggest that targeting fiscal transfers to poor communities is likely to yield higher returns than providing extra resources to richer communities.

Needless to say, these results do not imply that improving local management capacity and incentive and accountability structures is not desirable as a means of improving the

\footnotetext{
${ }^{28}$ The Real/\$ purchasing power parity exchange rate was about 1.4 [World Bank 2008].
} 
effectiveness of resource allocation in local governments. Results presented here should probably best be viewed as a lower bound on the effectiveness of resources without concomitant improvements in the externally imposed incentive environment. In further refinements I intend to investigate effects on individuals' earnings as well as heterogenous effects across income groups within counties. One would also expect resource effects on local housing, transportation and health conditions since these are the other main expenditure areas of local governments. It might also be interesting to examine whether counties which exhibit disproportionate increases in particular spending categories also show disproportionate changes in real outcomes along these dimensions. Resource effects might also differ depending on the pre-existing institutional and governance context. A final extension is to examine the impact of fiscal transfers on electoral outcomes.

Results presented here also suggest that the flypaper effect is real phenomenon among Brazilian local governments and not the result of mis-specification and omitted variable bias or failure to examine effects over time. In further work I intend to examine whether institutional factors, such as participatory budgeting processes, might dampen the flypaper effect on the theory that in such environments policy choices should more accurately reflect the preferences of the local population. 


\section{References}

Banco Nacional de Desenvolvimento Econômico e Social, 2002, "Municípios: os bons resultados orçamentários se repetem em 2001", Informe-se 49

—_,2003, "Carga Tributaria Global Estimativa para 2002", 2003, Informe-se 54

Banerjee, A., S. Jacob , M. Kremer, J. Lanjouw and P. Lanjouw, 2000, "Promoting School Participation in Rural Rajasthan", mimeo, MIT

Behrman, J. R., and N. Birdsall, 1983, "The Quality of Schooling: Quantity Alone is Misleading", American Economic Review, Vol. 73, No.5, pp. 928-946

Birdsall, N., 1985, Public Inputs and Child Schooling in Brazil, Journal of Development Economics, 18, pp. 67-86

Burnside, C. and D. Dollar, "Aid, policies and growth", American Economic Review, $90(4)$, pp. $847-868$

Card D. and A. B. Krueger, "Does School Quality Matter? Returns to Education and the Characteristics of Public School in the United States", Journal of Political Economy, February 1992, 100, pp. 1-40

Case, A. and A. Deaton, 1999, "School Inputs and Educational Outcomesin South Africa", Quarterly Journal of Economics, 114(3), pp. 1047-1085

Chin A., 2005, "Can Redistributing Teachers Across Schools Raise Educational Attainment? Evidence from Operation Blackboard in India", Journal of Development Economics, 78, pp. 384-405

Glewwe, P. and M. Kremer, 2006, "Schools, Teachers and Education Outcomes in Developing Countries", Handbook of the Economics of Education, Vol. 2

$\ldots, \ldots$, and Moulin, 2007, "Many Children Left Behind? Textbooks and Test Scores in Kenya", mimeo 
Clemens, M., S. Radelet and R. Bhavnani, 2004, "Counting chickens when they hatch: the short term effect of aid on growth", Center for Global Development Working Paper, No. 44,

Easterly, W., R. Levine and D. Roodman, 2004, "New Data, New Doubts: A Comment on Burnside and Dollar's 'Aid, policies and growth'", American Economic Review, Vol. 94(3), pp.774-780

Duflo E., 2001, "Schooling and Labor Market Consequences of School Construction in Indonesia: Evidence from an Unusual Policy Experiment", American Economic Review, 91(4), pp.795-814

—, P. Dupas and M. Kremer, 2007, "Peer Effects, Pupil-Teacher Ratios and Teacher Incentives: Evidence from a Randomized Evaluation in Kenya, unpublished manuscript

—, R. Glennerster and M. Kremer, 2007, "Using Randomization in Development Economics Research: A Toolkit". CEPR Working Paper 6059

Gordon, N. E., 2004, "Do Federal Funds Boost School Spending? Evidence from Title I," Journal of Public Economics, 88 (9-10), pp. 1771-92

Hahn, J., P. Todd, and W. Van der Klaauw, 2001, "Identification and Estimation of Treatment Effects with a Regression-Discontinuity Design", Econometrica, 69, 201209.

Hanushek, E. A., 2006, "School Resources", Handbook of the Economics of Education, Vol. 2

—, 1997, "Assessing the Effects of School Resources on Student Performance: An Update", Educational Evaluation and Policy Analysis, Vol. 19, No.2, pp. 141-164

Heckman, J. J., A. Layne-Farrar and P. Todd, 1996, "Does Measured School Quality Really Matter? An Examination of the Earnings-Quality Relationship", In Burtless 
Gary ed., Does Money Matter? The Effect of School Resources on Student Achievement and Adult Success, Washington, D. D., Brookings Institution, pp. 192-289

Heckman, J. J., L. Lochner and C. Taber, 1998, "General Equilibrium Treatment Effects: A Study of Tuition Policy", American Economic Review, Vol. 88, No. 2, Papers and Proceedings of the Hundreth and Tenth Annual Meeting of the American Economic Association, pp. 381-386

Hines, J. R. and R. H. Thaler, 1995, "Anomalies: The Flypaper Effect", Journal of Economic Perspectives, Vol. 9, No. 4, pp. 217-26

Hoxby C. M., 2000, "The effects of class size on student achievement: New evidence from population variation", Quarterly Journal of Economics, vol. 115, Issue 3, pp. $1239-1285$

Imbens, G. and T. Lemieux, 2007, "Regression Discontinuity Designs: A Guide to Practice", Journal of Econometrics, 2007, forthcoming, pp. 1-20

Instituto Brasileiro de Geografia e Estatistica, 2002, "Estimativas Populacionais do Brasil, Grandes Regioes, Unidades da Federacao e Municípios", IBGE background paper, Rio de Janeiro

Knight, B., 2002, "Endogenous Federal Grants and Crowd-out of State Government Spending: Theory and Evidence form the Federal Highway Aid Program", American Economic Review, Vol. 92, No. 1, pp.71-92

Krueger, A. B., 2003, "Economic Considerations and Class Size, " Economic Journal, vol. 113, February 2003, pp. 34-63

and D. M. Whitmore, 2001, "The Effect of Attending a Small Class in the Early Grades on College-Test Taking and Middle School Test Results: Evidence from Project STAR", Economic Journal, vol. 111, January 2001, pp. 1-28

Lee, D., 2007, "Randomized Experiments from Non-random Selection in U.S. House Elections", Journal of Econometrics, forthcoming 
Ludwig, J. and D. L. Miller, 2007, "Does Head Start Improve Children's Life Chances? Evidence from a Regression Discontinuity Design", Quarterly Journal of Economics, 122(1), 159-208

McCrary, J., 2007, "Manipulation of the Running Variable in the Regression Discontinuity Design: A Density Test", Journal of Econometrics, forthcoming

Muralidharan, K. and V. Sundararaman, 2006, "Teacher Incentives in Developing Countries: Experimental Evidence from India", unpublished manuscript

Porter, J., 2003, "Estimation in the Regression Discontinuity Model", unpublished manuscript, Department of Economics, University of Wisconsin

Tribunal de Contas da Uniao, 1981, Resolucao No. 208/81 and No. 209/81

Van der Klaauw, W., 2002, "Estimating the Effect of Financial Aid Offers on College Enrollment: A Regression Discontinuity Approach," International Economic Review, $43(4), 1249-1287$

World Bank, 1985, Brazil: Finance of Primary Education, Washington D.C.

Worthington A. C. and B. E. Dollery, 1999, "Fiscal Illusion and Australian local government grant process: How sticky is the flypaper effect?", Public Choice, 99, pp.1-13 
Figure 1: FPM transfers 1982-1985

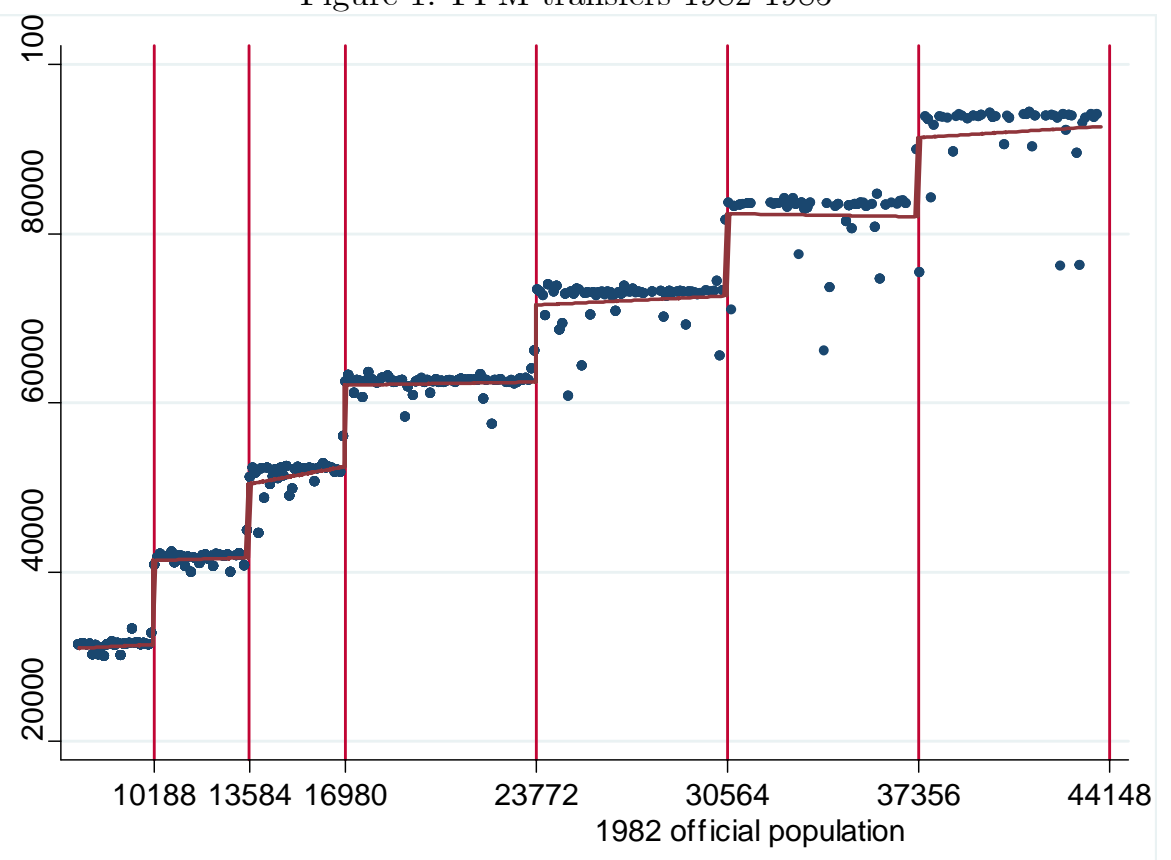

Table I

\begin{tabular}{llllc}
\hline \multicolumn{4}{c}{ Population bracket } & Coefficient \\
up to & 10,188 & & & 0.6 \\
from & 10,189 & to & 13,584 & 0.8 \\
from & 13,585 & to & 16,980 & 1 \\
from & 16,981 & to & 23,772 & 1.2 \\
from & 23,773 & to & 30,564 & 1.4 \\
from & 30,565 & to & 37,356 & 1.6 \\
from & 37,357 & to & 44,148 & 1.8 \\
from & 44,149 & to & 50,940 & 2 \\
from & 50,941 & to & 61,128 & 2.2 \\
from & 61,129 & to & 71,316 & 2.4 \\
from & 71,317 & to & 81,504 & 2.6 \\
from & 81,505 & to & 91,692 & 2.8 \\
from & 91,693 & to & 101,880 & 3 \\
from & 101,881 & to & 115,464 & 3.2 \\
from & 115,465 & to & 129,048 & 3.4 \\
from & 129,049 & to & 142,632 & 3.6 \\
from & 142,633 & to & 156,216 & 3.8 \\
above & 156,216 & & & 4 \\
\hline \multicolumn{5}{l}{ Source: Decree $1881 / 81$} \\
\end{tabular}


Figure 2: FPM transfers timeline

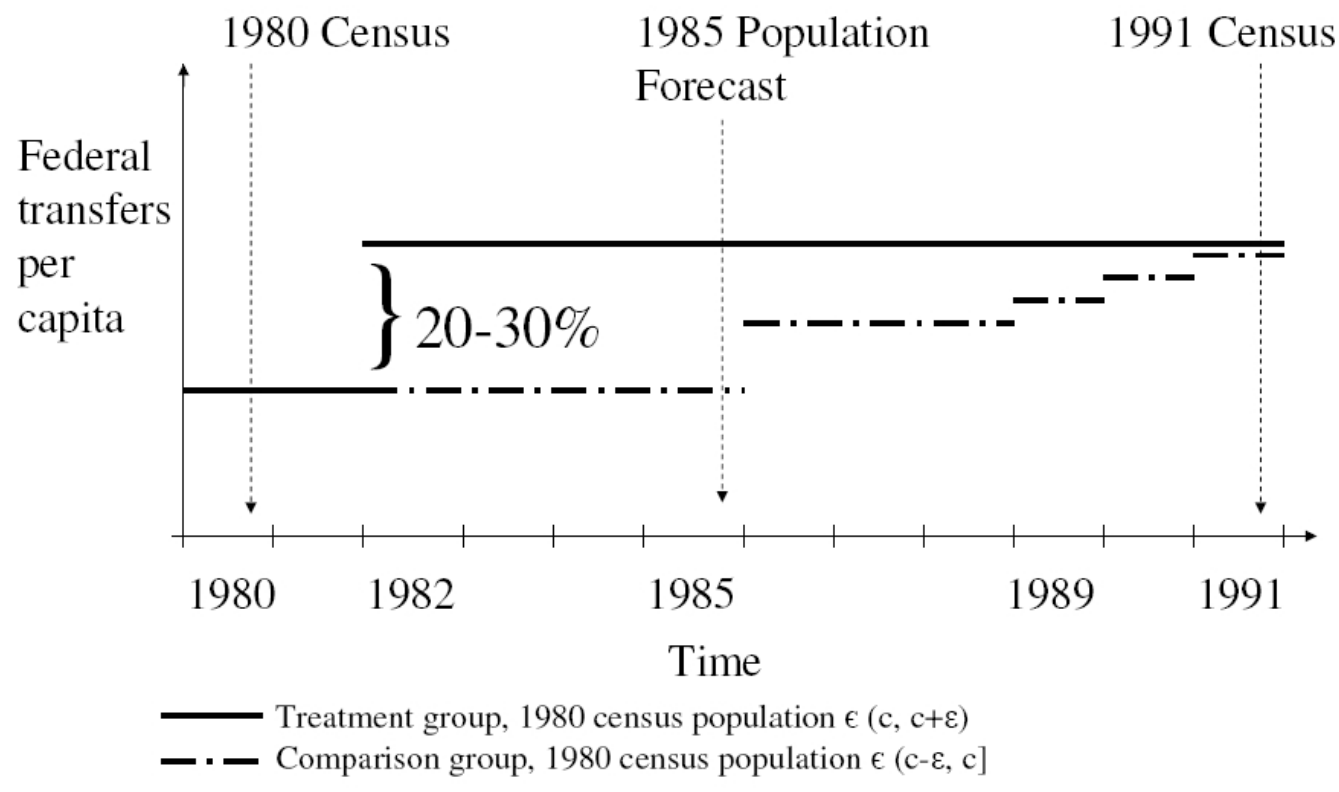

Figure 3: the flypaper effect illustrated

\section{Private}

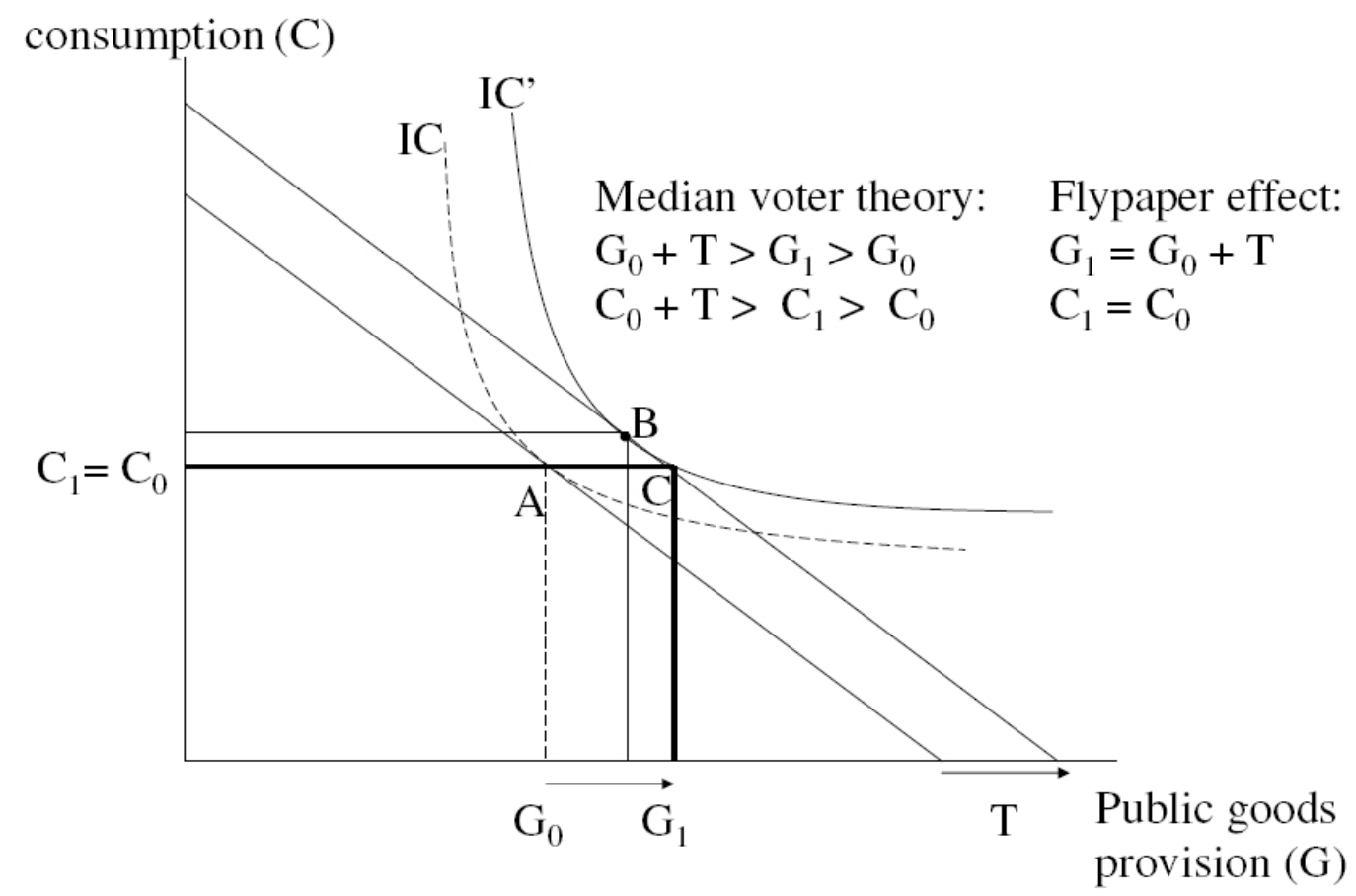

Figure 4: 
Table II: Descriptive statistics

\begin{tabular}{|c|c|c|c|c|c|c|}
\hline & \multicolumn{5}{|c|}{ Population range } & \multirow[b]{3}{*}{ Urban } \\
\hline & \multicolumn{2}{|l|}{$7,500-44,148$} & \multicolumn{3}{|c|}{$8,500-18,700$} & \\
\hline Sample & Full & Full & North & South & Rural & \\
\hline \multicolumn{7}{|l|}{1980 county characteristics (IBGE) } \\
\hline Avg. years of schooling ( 25 years and older) & 2.0 & 1.9 & 1.0 & 2.5 & 1.5 & 2.3 \\
\hline Percentage of residents living in urban areas $(\%)$ & 30.0 & 27.9 & 22.4 & 32.2 & 14.8 & 41.7 \\
\hline Net enrollment rate of 7 to 14 year olds (\%) & 55.6 & 55.5 & 39.4 & 67.6 & 48.9 & 62.1 \\
\hline Illiteracy, 15 years and older $(\%)$ & 39.0 & 39.1 & 55.9 & 26.3 & 44,4 & 33.7 \\
\hline Poverty headcount ratio (national poverty line, \%) & 58.6 & 59.3 & 78.0 & 45.3 & 67.9 & 50.7 \\
\hline Income per capita (\% of minimum salary in 1991 ) & 77.5 & 75.2 & 41.0 & 101.0 & 58.6 & 91.9 \\
\hline Infant mortality (per 1000 life births) & 88.9 & 88.5 & 129.0 & 57.6 & 96 & 80.7 \\
\hline GDP ('000) 2005 Reais (IPEA) & 93,101 & 55,056 & 28,314 & 75,217 & 40,149 & 70,084 \\
\hline \multicolumn{7}{|l|}{1982 Financial data (Ministry of Finance) } \\
\hline Total county revenue ('000) 2005 Reais & 31,188 & 22,672 & 14,389 & 28,081 & 18,601 & 26,525 \\
\hline Total county revenue 1982/GDP 1980 (\%) & 48.6 & 51.6 & 67.0 & 41.5 & 57.5 & 46.0 \\
\hline FPM transfers/total revenue $(\%)$ & 48.0 & 49.7 & 66.4 & 37.8 & 56.4 & 42.3 \\
\hline Own revenue/total revenue $(\%)$ & 5.9 & 5.1 & 1.1 & 7.7 & 2.6 & 7.5 \\
\hline Other revenue/total revenue $(\%)$ & 46.9 & 45.9 & 32.9 & 54.7 & 41.9 & 49.7 \\
\hline Administrative spending/total spending (\%) & 22.3 & 22.3 & 22.9 & 21.7 & 21.8 & 22.9 \\
\hline Education spending/total spending (\%) & 20.9 & 21.2 & 23.9 & 18.6 & 22.3 & 20.0 \\
\hline Housing spending/total spending (\%) & 19.5 & 17.9 & 19.9 & 16.0 & 15.9 & 20.2 \\
\hline Health spending/total spending $(\%)$ & 9.9 & 10.4 & 14.3 & 6.3 & 11.1 & 9.6 \\
\hline Transportation spending/total spending (\%) & 20.9 & 21.8 & 12.2 & 30.0 & 23.2 & 20.2 \\
\hline Other spending/total spending $(\%)$ & 8.5 & 8.5 & 8.5 & 8.5 & 8.2 & 8.6 \\
\hline \multicolumn{7}{|l|}{1991 Real school resources (1991 school census) } \\
\hline Number of municipal elementary schools & 37.8 & 30.2 & 41.3 & 19.8 & 37.5 & 21.4 \\
\hline Primary school teacher-student ratio & 0.054 & 0.056 & 0.047 & 0.064 & 0.054 & 0.059 \\
\hline \multicolumn{7}{|l|}{1991 School outcomes (1991 census) } \\
\hline Avg. years of completed schooling (19 to 28 olds) & 4.6 & 4.5 & 3.3 & 5.5 & 4 & 5.1 \\
\hline Literacy rate (19 to 28 olds) & 78.8 & 79.0 & 63.0 & 91.0 & 73.7 & 84.3 \\
\hline
\end{tabular}




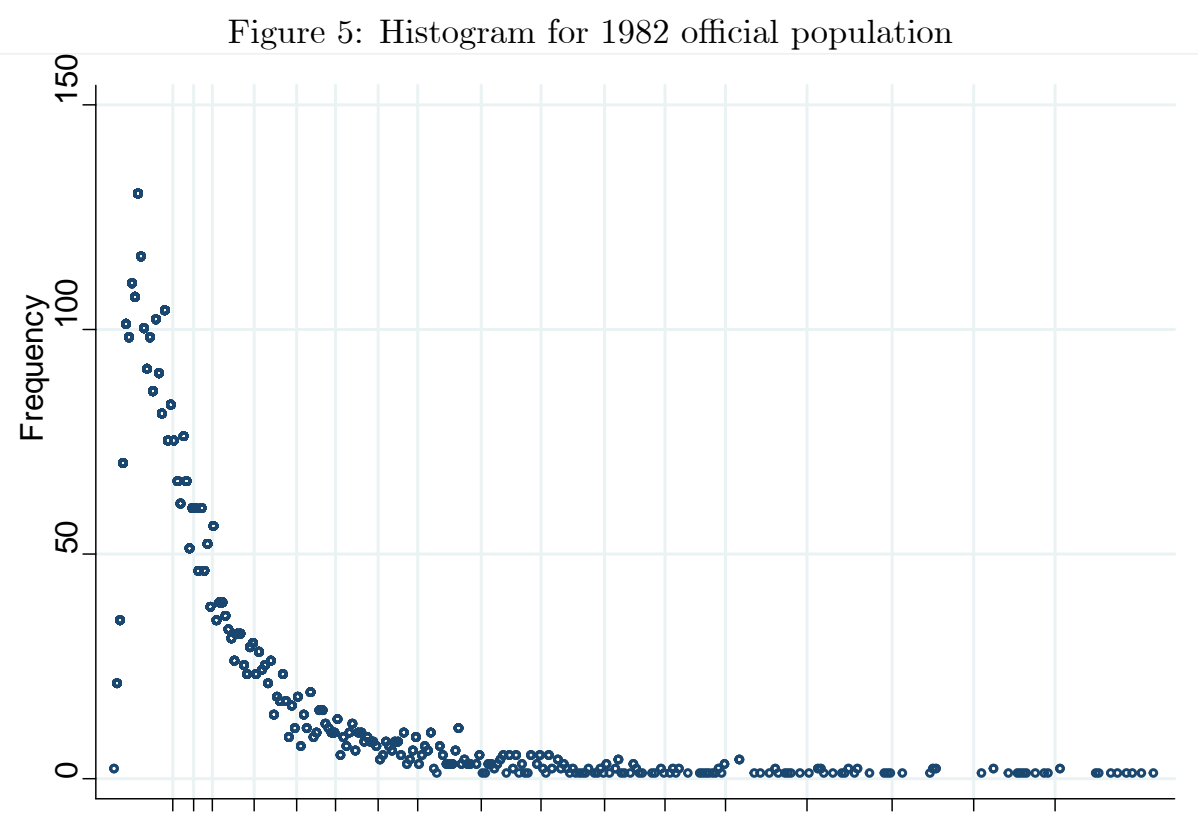

Official 1982 population

Figure 6: Histogram for 1982 official population, focused plot

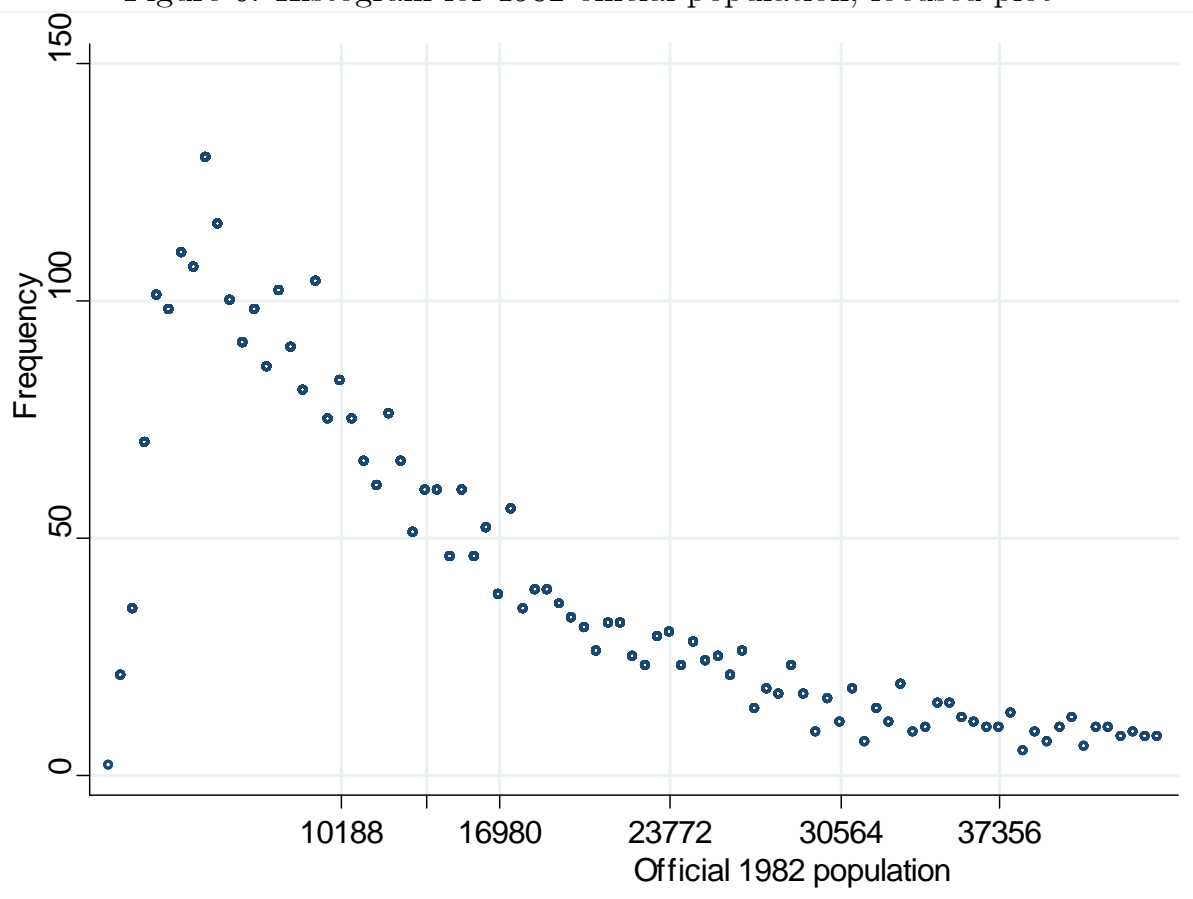


Figure 7: $\log$ per capita total revenue 1981

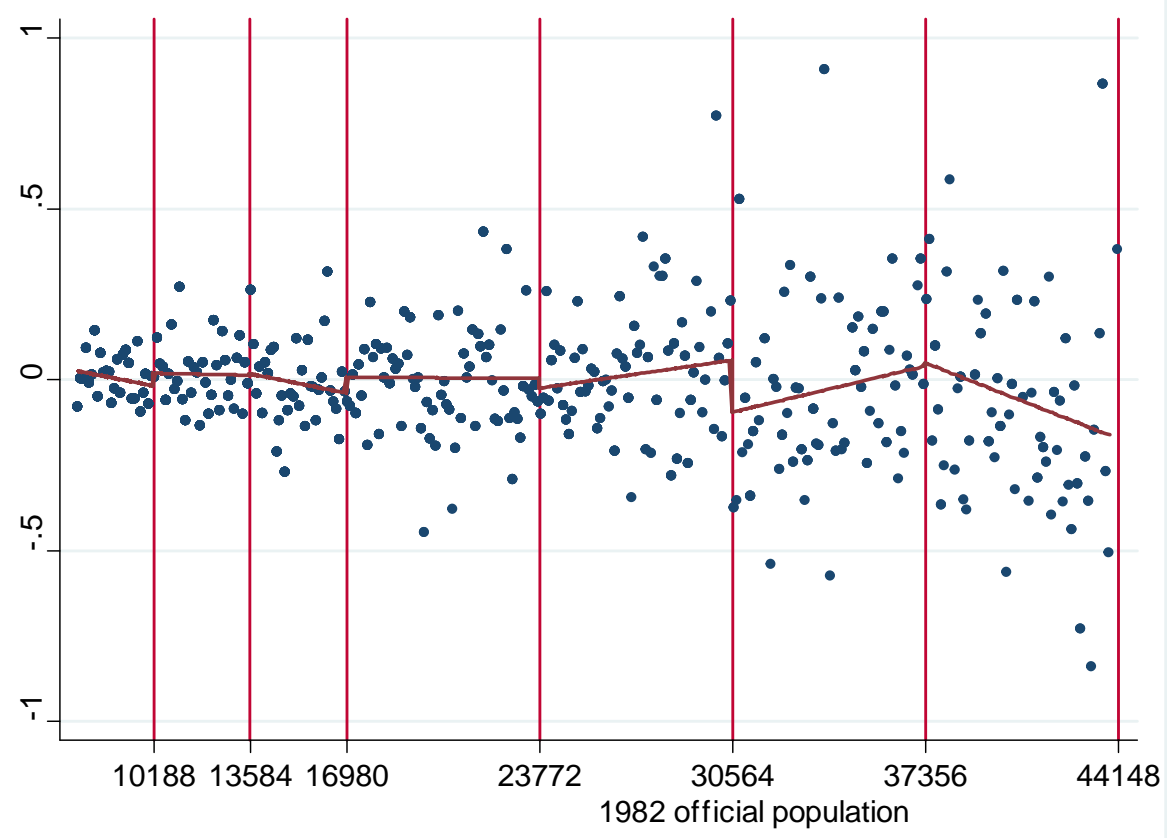

Dependent Variable: log per capita total revenue 1981

\begin{tabular}{lllllll}
\hline Specification: & Linear & Linear & Quadratic & Quadratic & Cubic & Cubic \\
& & & & & & \\
$\mathrm{I}[\mathrm{x}>10188]$ & 0.031 & 0.011 & 0.112 & 0.057 & 0.133 & 0.094 \\
& $(0.037)$ & $(0.034)$ & $(0.052)^{* *}$ & $(0.048)$ & $(0.068)^{*}$ & $(0.065)$ \\
$\mathrm{I}[\mathrm{x}>13584]$ & 0.020 & -0.009 & 0.036 & 0.032 & 0.094 & 0.086 \\
& $(0.053)$ & $(0.046)$ & $(0.079)$ & $(0.067)$ & $(0.097)$ & $(0.080)$ \\
$\mathrm{I}[\mathrm{x}>16980]$ & 0.096 & 0.075 & 0.024 & 0.007 & 0.067 & 0.035 \\
& $(0.055)^{*}$ & $(0.045)^{*}$ & $(0.072)$ & $(0.058)$ & $(0.083)$ & $(0.065)$ \\
$\mathrm{I}[\mathrm{x}>23772]$ & -0.009 & -0.046 & 0.032 & -0.006 & -0.009 & -0.103 \\
& $(0.052)$ & $(0.045)$ & $(0.066)$ & $(0.060)$ & $(0.083)$ & $(0.074)$ \\
I[x>30564] & -0.164 & -0.140 & -0.087 & -0.095 & -0.048 & -0.126 \\
& $(0.086)^{*}$ & $(0.068)^{* *}$ & $(0.134)$ & $(0.105)$ & $(0.181)$ & $(0.140)$ \\
I[x>37356] & -0.033 & -0.091 & -0.078 & -0.089 & -0.029 & -0.064 \\
& $(0.103)$ & $(0.081)$ & $(0.142)$ & $(0.105)$ & $(0.196)$ & $(0.143)$ \\
Schooling 1980 & & 0.107 & & 0.106 & & 0.107 \\
& & $(0.023)^{* * *}$ & & $(0.022)^{* * *}$ & & $(0.023)^{* * *}$ \\
Illiteracy 1980 & & 0.001 & & 0.001 & & 0.001 \\
& & $(0.001)$ & & $(0.001)$ & & $(0.001)$ \\
Poverty 1980 & & -0.005 & & -0.005 & & -0.005 \\
& & $(0.001)^{* * *}$ & & $(0.001)^{* * *}$ & & $(0.001)^{* * *}$ \\
Income pcap 1980 & & 0.308 & & 0.311 & & 0.308 \\
Mortality 1980 & & $(0.057)^{* * *}$ & & $(0.057)^{* * *}$ & & $(0.057)^{* * *}$ \\
& & -0.000 & & -0.000 & & -0.000 \\
Observations & 2239 & 2239 & 2240 & 2239 & 2240 & 2239 \\
R-squared & 0.62 & 0.72 & 0.62 & 0.72 & 0.62 & 0.72 \\
& & & & & \\
\hline
\end{tabular}


Figure 8: $\log$ per capita education spending 1981

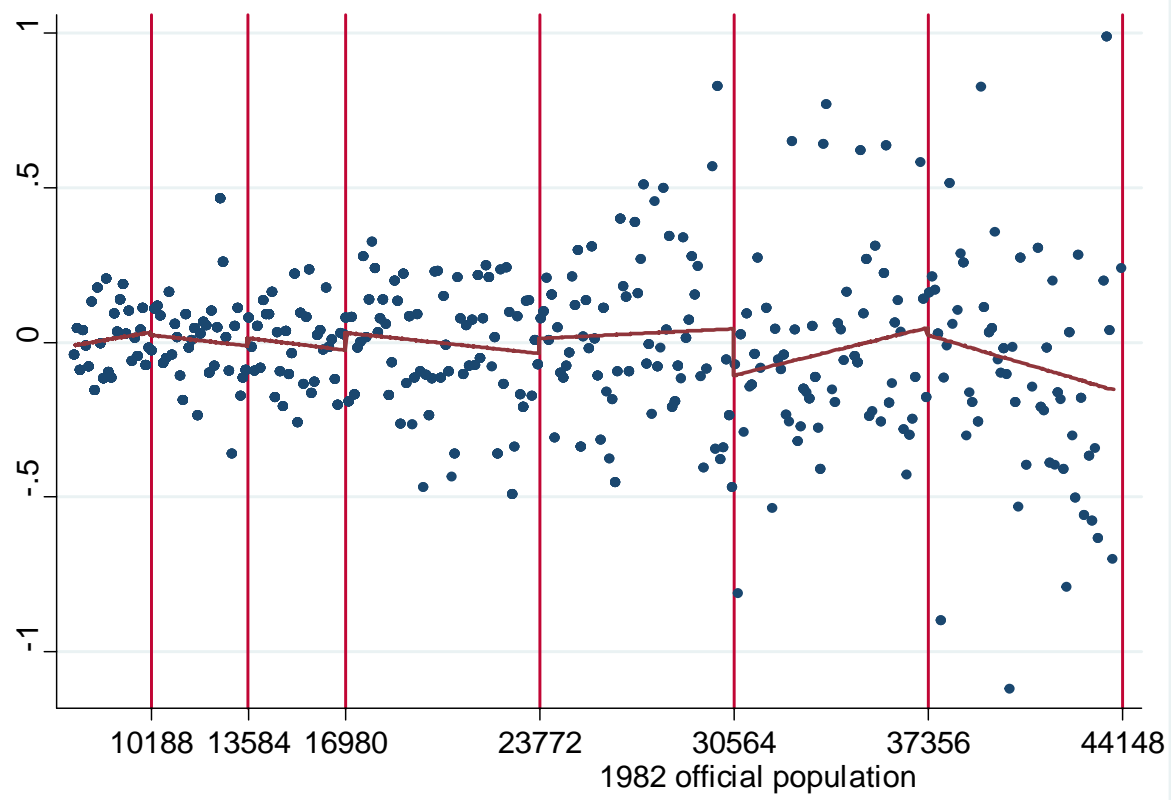

Dependent Variable: log per capita education expenditure 1981

\begin{tabular}{|c|c|c|c|c|c|c|}
\hline Specification: & Linear & Linear & Quadratic & Quadratic & Cubic & Cubic \\
\hline $\mathrm{I}[\mathrm{x}>10188]$ & $\begin{array}{l}-0.005 \\
(0.057)\end{array}$ & $\begin{array}{l}-0.026 \\
(0.056)\end{array}$ & $\begin{array}{l}0.051 \\
(0.084)\end{array}$ & $\begin{array}{l}0.002 \\
(0.084)\end{array}$ & $\begin{array}{l}0.239 \\
(0.108)^{* * *}\end{array}$ & $\begin{array}{l}0.194 \\
(0.107)^{*}\end{array}$ \\
\hline $\mathrm{I}[\mathrm{x}>13584]$ & $\begin{array}{l}0.038 \\
(0.066)\end{array}$ & $\begin{array}{l}0.026 \\
(0.064)\end{array}$ & $\begin{array}{l}0.039 \\
(0.091)\end{array}$ & $\begin{array}{l}0.052 \\
(0.087)\end{array}$ & $\begin{array}{l}0.134 \\
(0.109)\end{array}$ & $\begin{array}{l}0.130 \\
(0.102)\end{array}$ \\
\hline $\mathrm{I}[\mathrm{x}>16980]$ & $\begin{array}{l}0.083 \\
(0.068)\end{array}$ & $\begin{array}{l}0.070 \\
(0.067)\end{array}$ & $\begin{array}{l}0.073 \\
(0.094)\end{array}$ & $\begin{array}{l}0.060 \\
(0.094)\end{array}$ & $\begin{array}{l}0.030 \\
(0.120)\end{array}$ & $\begin{array}{l}0.001 \\
(0.126)\end{array}$ \\
\hline $\mathrm{I}[\mathrm{x}>23772]$ & $\begin{array}{l}0.101 \\
(0.080)\end{array}$ & $\begin{array}{l}0.081 \\
(0.076)\end{array}$ & $\begin{array}{l}0.098 \\
(0.106)\end{array}$ & $\begin{array}{l}0.070 \\
(0.103)\end{array}$ & $\begin{array}{l}0.088 \\
(0.133)\end{array}$ & $\begin{array}{l}0.020 \\
(0.128)\end{array}$ \\
\hline $\mathrm{I}[\mathrm{x}>30564]$ & $\begin{array}{l}-0.136 \\
(0.116)\end{array}$ & $\begin{array}{l}-0.121 \\
(0.111)\end{array}$ & $\begin{array}{l}-0.127 \\
(0.192)\end{array}$ & $\begin{array}{l}-0.131 \\
(0.184)\end{array}$ & $\begin{array}{l}-0.061 \\
(0.269)\end{array}$ & $\begin{array}{l}-0.115 \\
(0.261)\end{array}$ \\
\hline $\mathrm{I}[\mathrm{x}>37356]$ & $\begin{array}{l}-0.088 \\
(0.127)\end{array}$ & $\begin{array}{l}-0.121 \\
(0.122)\end{array}$ & $\begin{array}{l}0.062 \\
(0.170)\end{array}$ & $\begin{array}{l}0.056 \\
(0.163)\end{array}$ & $\begin{array}{l}-0.060 \\
(0.210)\end{array}$ & $\begin{array}{l}-0.074 \\
(0.201)\end{array}$ \\
\hline Schooling 1980 & & $\begin{array}{l}0.079 \\
(0.032) * *\end{array}$ & & $\begin{array}{l}0.078 \\
(0.032)^{* *}\end{array}$ & & $\begin{array}{l}0.076 \\
(0.032)^{* *}\end{array}$ \\
\hline Illiteracy 1980 & & $\begin{array}{l}0.001 \\
(0.002)\end{array}$ & & $\begin{array}{l}0.000 \\
(0.002)\end{array}$ & & $\begin{array}{l}0.000 \\
(0.002)\end{array}$ \\
\hline Poverty 1980 & & $\begin{array}{l}-0.003 \\
(0.002)\end{array}$ & & $\begin{array}{l}-0.003 \\
(0.002)\end{array}$ & & $\begin{array}{l}-0.003 \\
(0.002)\end{array}$ \\
\hline Income pcap 1980 & & $\begin{array}{l}0.254 \\
(0.080) * * *\end{array}$ & & $\begin{array}{l}0.253 \\
(0.079) * * *\end{array}$ & & $\begin{array}{l}0.250 \\
(0.080)^{* * * *}\end{array}$ \\
\hline Mortality 1980 & & $\begin{array}{l}-0.000 \\
(0.000)\end{array}$ & & $\begin{array}{l}-0.000 \\
(0.000)\end{array}$ & & $\begin{array}{l}-0.000 \\
(0.000)\end{array}$ \\
\hline Observations & 2001 & 2000 & 2001 & 2000 & 2001 & 2000 \\
\hline R-squared & 0.43 & 0.47 & 0.43 & 0.48 & 0.43 & 0.48 \\
\hline
\end{tabular}


Figure 9: log per capita FPM transfers 1982-1985

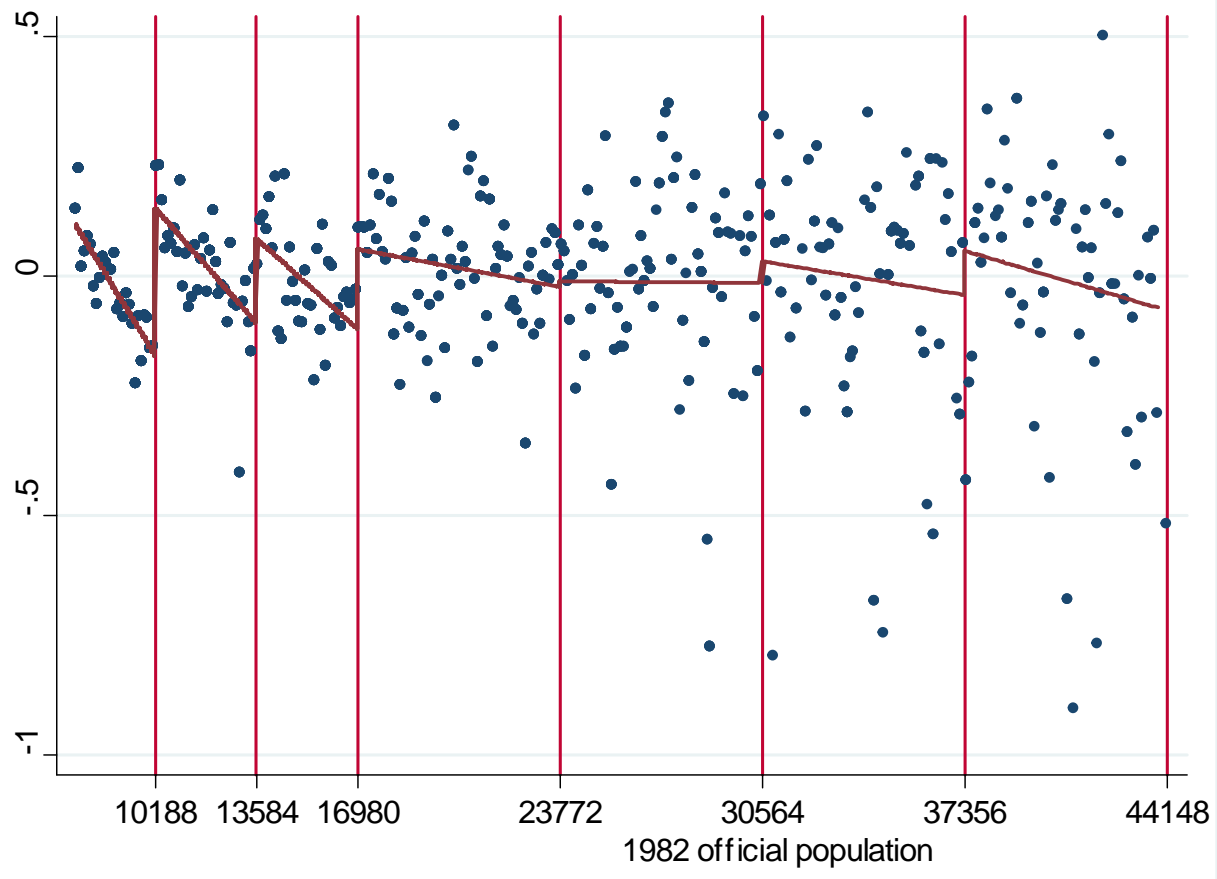

Dependent Variable: log per capita FPM transfers 1982-1985

\begin{tabular}{lllllll} 
Specification: & Linear & Linear & Quadratic & Quadratic & Cubic & Cubic \\
I[x>10188] & 0.330 & 0.326 & 0.346 & 0.346 & 0.378 & 0.380 \\
& $(0.039)^{* * *}$ & $(0.039)^{* * *}$ & $(0.052)^{* * *}$ & $(0.053)^{* * *}$ & $(0.068)^{* * *}$ & $(0.069)^{* * *}$ \\
$\mathrm{I}[\mathrm{x}>13584]$ & 0.208 & 0.200 & 0.240 & 0.228 & 0.276 & 0.268 \\
& $(0.047)^{* * *}$ & $(0.047)^{* * *}$ & $(0.068)^{* * *}$ & $(0.068)^{* * *}$ & $(0.087)^{* * *}$ & $(0.087)^{* * *}$ \\
$\mathrm{I}[\mathrm{x}>16980]$ & 0.210 & 0.208 & 0.205 & 0.207 & 0.219 & 0.225 \\
& $(0.044)^{* * *}$ & $(0.044)^{* * *}$ & $(0.061)^{* * *}$ & $(0.061)^{* * *}$ & $(0.081)^{* * *}$ & $(0.081)^{* * *}$ \\
$\mathrm{I}[\mathrm{x}>23772]$ & 0.153 & 0.151 & 0.046 & 0.042 & -0.023 & -0.028 \\
& $(0.047)^{* * *}$ & $(0.047)^{* * *}$ & $(0.061)$ & $(0.061)$ & $(0.083)$ & $(0.083)$ \\
$\mathrm{I}[\mathrm{x}>30564]$ & 0.154 & 0.153 & 0.229 & 0.226 & 0.229 & 0.229 \\
& $(0.072)^{* *}$ & $(0.071)^{* *}$ & $(0.096)^{* *}$ & $(0.096)^{* *}$ & $(0.117)^{*}$ & $(0.116)^{* *}$ \\
$\mathrm{I}[\mathrm{x}>37356]$ & 0.109 & 0.111 & 0.065 & 0.067 & 0.112 & 0.125 \\
& $(0.087)$ & $(0.087)$ & $(0.131)$ & $(0.131)$ & $(0.168)$ & $(0.167)$ \\
Schooling 1980 & & 0.030 & & 0.031 & & 0.032 \\
& & $(0.023)$ & & $(0.023)$ & & $(0.023)$ \\
Illiteracy 1980 & & 0.001 & & 0.001 & & 0.001 \\
& & $(0.001)$ & & $(0.001)$ & & $(0.001)$ \\
Poverty 1980 & & -0.001 & & -0.001 & & -0.001 \\
& & $(0.001)$ & & $(0.001)$ & & $(0.001)$ \\
Income pcap 1980 & & -0.057 & & -0.058 & & -0.059 \\
& & $(0.055)$ & & $(0.055)$ & & $(0.055)$ \\
Mortality 1980 & & -0.001 & & -0.001 & & -0.001 \\
& & $(0.000)^{* *}$ & & $(0.000)^{* *}$ & & $(0.000)^{* *}$ \\
Observations & 2284 & 2283 & 2284 & 2283 & 2284 & 2283 \\
R-squared & 0.35 & 0.35 & 0.35 & 0.36 & 0.35 & 0.36 \\
& & & & & & \\
\hline
\end{tabular}


Figure 10: log per capita total revenue 1982-1985

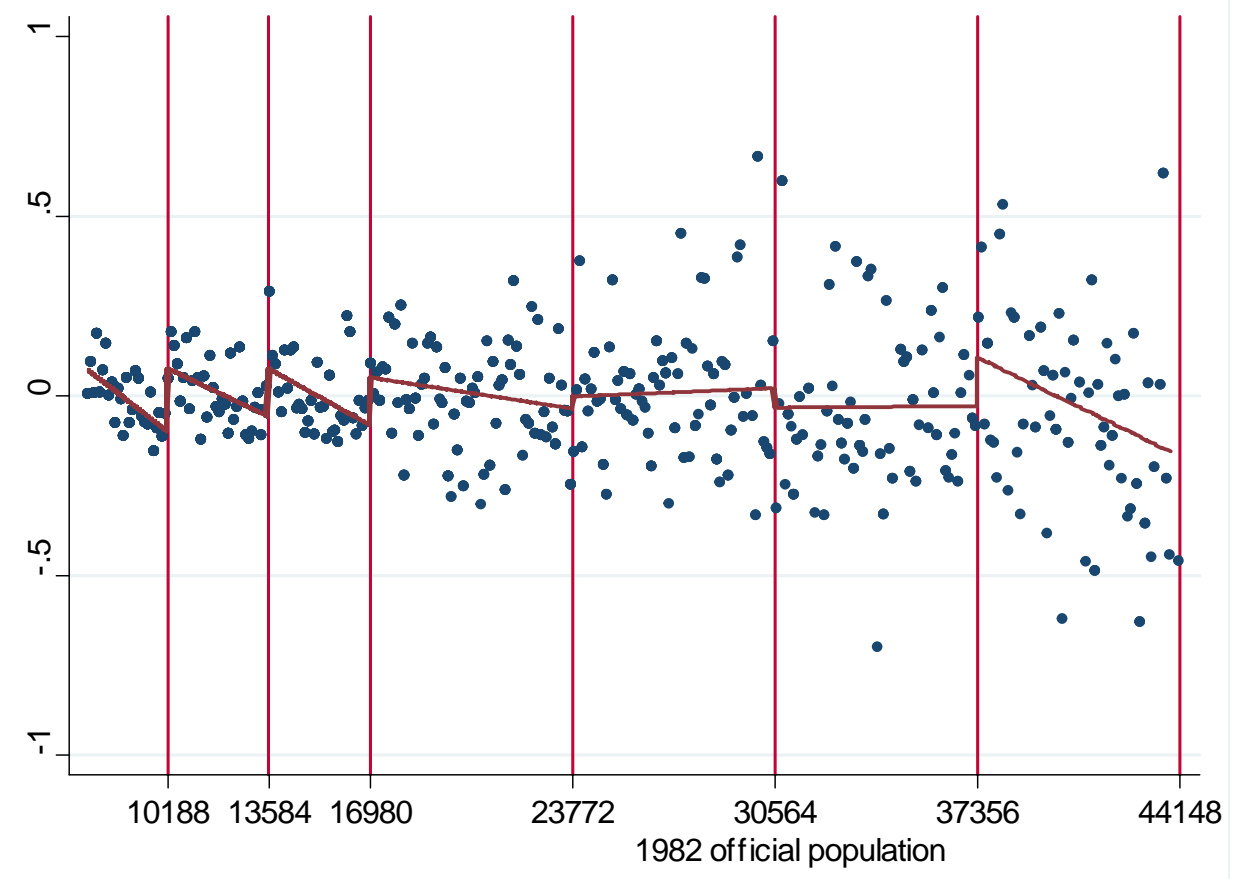

Dependent Variable: log per capita total revenue 1982-1985

\begin{tabular}{lllllll} 
Specification: & Linear & Linear & Quadratic & Quadratic & Cubic & Cubic \\
& & & & & & \\
$\mathrm{I}[\mathrm{x}>10188]$ & 0.171 & 0.143 & 0.224 & 0.165 & 0.225 & 0.180 \\
& $(0.037)^{* * *}$ & $(0.032)^{* * *}$ & $(0.051)^{* * *}$ & $(0.047)^{* * *}$ & $(0.066)^{* * *}$ & $(0.063)^{* * *}$ \\
$\mathrm{I}[\mathrm{x}>13584]$ & 0.130 & 0.097 & 0.153 & 0.144 & 0.160 & 0.140 \\
& $(0.050)^{* * *}$ & $(0.041)^{* *}$ & $(0.074)^{* *}$ & $(0.060)^{* *}$ & $(0.093)^{*}$ & $(0.074)^{*}$ \\
$\mathrm{I}[\mathrm{x}>16980]$ & 0.156 & 0.128 & 0.098 & 0.078 & 0.133 & 0.091 \\
& $(0.052)^{* * *}$ & $(0.040)^{* * *}$ & $(0.066)$ & $(0.049)$ & $(0.079)^{*}$ & $(0.055)^{*}$ \\
$\mathrm{I}[\mathrm{x}>23772]$ & 0.067 & 0.032 & 0.023 & -0.008 & 0.059 & -0.007 \\
& $(0.053)$ & $(0.042)$ & $(0.072)$ & $(0.058)$ & $(0.096)$ & $(0.075)$ \\
$\mathrm{I}[\mathrm{x}>30564]$ & -0.065 & -0.034 & 0.029 & 0.017 & 0.193 & 0.124 \\
& $(0.081)$ & $(0.058)$ & $(0.127)$ & $(0.092)$ & $(0.169)$ & $(0.121)$ \\
$\mathrm{I}[\mathrm{x}>37356]$ & 0.112 & 0.040 & 0.118 & 0.089 & 0.226 & 0.159 \\
& $(0.090)$ & $(0.064)$ & $(0.116)$ & $(0.077)$ & $(0.142)$ & $(0.089)^{*}$ \\
Schooling 1980 & & 0.097 & & 0.096 & & 0.096 \\
& & $(0.021)^{* * * *}$ & & $(0.021)^{* * *}$ & & $(0.021)^{* * *}$ \\
Illiteracy 1980 & & 0.001 & & 0.001 & & 0.001 \\
& & $(0.001)$ & & $(0.001)$ & & $(0.001)$ \\
Poverty 1980 & & -0.007 & & -0.007 & & -0.007 \\
& & $(0.001)^{* * *}$ & & $(0.001)^{* * *}$ & & $(0.001)^{* * *}$ \\
Income pcap 1980 & & 0.296 & & 0.297 & & 0.295 \\
& & $(0.048)^{* * *}$ & & $(0.048)^{* * *}$ & & $(0.048)^{* * *}$ \\
Mortality 1980 & & -0.000 & & -0.000 & & -0.000 \\
& & $(0.000)$ & & $(0.000)$ & & $(0.000)$ \\
Observations & 2296 & 2296 & 2297 & 2296 & 2297 & 2296 \\
R-squared & 0.62 & 0.75 & 0.62 & 0.75 & 0.63 & 0.75 \\
& & & & & & \\
\hline
\end{tabular}


Figure 11: log per capita own revenue 1982-1985

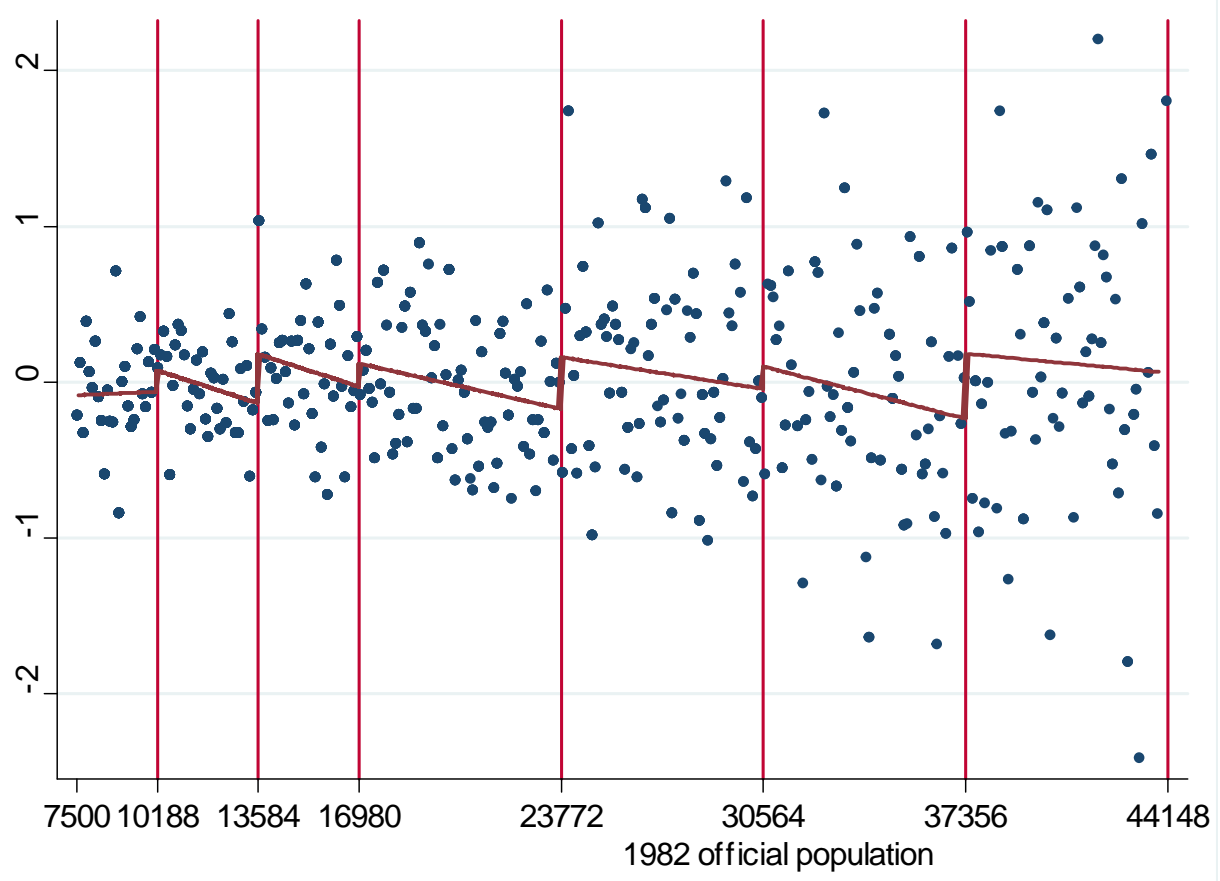

Figure 12:

Dependent Variable: $\log$ per capita own revenue 1982-1985

\begin{tabular}{|c|c|c|c|c|c|c|}
\hline Specification: & Linear & Linear & Quadratic & Quadratic & Cubic & Cubic \\
\hline $\mathrm{I}[\mathrm{x}>10188]$ & $\begin{array}{c}0.101 \\
(0.150)\end{array}$ & $\begin{array}{l}-0.007 \\
(0.129)\end{array}$ & $\begin{array}{c}0.036 \\
(0.213)\end{array}$ & $\begin{array}{l}-0.167 \\
(0.184)\end{array}$ & $\begin{array}{c}0.151 \\
(0.258)\end{array}$ & $\begin{array}{c}0.007 \\
(0.218)\end{array}$ \\
\hline $\mathrm{I}[\mathrm{x}>13584]$ & $\begin{array}{c}0.260 \\
(0.171)\end{array}$ & $\begin{array}{c}0.083 \\
(0.139)\end{array}$ & $\begin{array}{c}0.255 \\
(0.270)\end{array}$ & $\begin{array}{c}0.131 \\
(0.218)\end{array}$ & $\begin{array}{c}0.413 \\
(0.343)\end{array}$ & $\begin{array}{c}0.278 \\
(0.271)\end{array}$ \\
\hline $\mathrm{I}[\mathrm{x}>16980]$ & $\begin{array}{c}0.102 \\
(0.180)\end{array}$ & $\begin{array}{l}-0.028 \\
(0.141)\end{array}$ & $\begin{array}{c}0.046 \\
(0.234)\end{array}$ & $\begin{array}{l}-0.027 \\
(0.178)\end{array}$ & $\begin{array}{c}0.005 \\
(0.300)\end{array}$ & $\begin{array}{l}-0.114 \\
(0.217)\end{array}$ \\
\hline $\mathrm{I}[\mathrm{x}>23772]$ & $\begin{array}{l}-0.047 \\
(0.347)\end{array}$ & $\begin{array}{l}-0.120 \\
(0.278)\end{array}$ & $\begin{array}{l}-0.069 \\
(0.421)\end{array}$ & $\begin{array}{l}-0.170 \\
(0.328)\end{array}$ & $\begin{array}{l}-0.363 \\
(0.556)\end{array}$ & $\begin{array}{c}-0.534 \\
(0.422)\end{array}$ \\
\hline $\mathrm{I}[\mathrm{x}>30564]$ & $\begin{array}{l}-0.053 \\
(0.243)\end{array}$ & $\begin{array}{l}-0.025 \\
(0.181)\end{array}$ & $\begin{array}{c}0.069 \\
(0.336)\end{array}$ & $\begin{array}{c}-0.045 \\
(0.250)\end{array}$ & $\begin{array}{c}0.364 \\
(0.426)\end{array}$ & $\begin{array}{c}0.067 \\
(0.325)\end{array}$ \\
\hline $\mathrm{I}[\mathrm{x}>37356]$ & $\begin{array}{c}0.323 \\
(0.267)\end{array}$ & $\begin{array}{c}0.035 \\
(0.189)\end{array}$ & $\begin{array}{c}0.225 \\
(0.390)\end{array}$ & $\begin{array}{c}0.067 \\
(0.272)\end{array}$ & $\begin{array}{c}0.438 \\
(0.489)\end{array}$ & $\begin{array}{c}0.062 \\
(0.341)\end{array}$ \\
\hline Schooling 1980 & & $\begin{array}{c}0.623 \\
(0.067)^{* * *}\end{array}$ & & $\begin{array}{c}0.623 \\
(0.067)^{* * *}\end{array}$ & & $\begin{array}{c}0.622 \\
(0.067)^{* * *}\end{array}$ \\
\hline Illiteracy 1980 & & $\begin{array}{l}-0.000 \\
(0.004)\end{array}$ & & $\begin{array}{l}-0.000 \\
(0.004)\end{array}$ & & $\begin{array}{l}-0.000 \\
(0.004)\end{array}$ \\
\hline Poverty 1980 & & $\begin{array}{c}-0.026 \\
(0.003)^{* * *}\end{array}$ & & $\begin{array}{c}-0.026 \\
(0.003)^{* * *}\end{array}$ & & $\begin{array}{c}-0.026 \\
(0.003)^{* * *}\end{array}$ \\
\hline Income pcap 1980 & & $\begin{array}{c}0.192 \\
(0.122)\end{array}$ & & $\begin{array}{c}0.191 \\
(0.123)\end{array}$ & & $\begin{array}{c}0.197 \\
(0.123)\end{array}$ \\
\hline Mortality 1980 & & $\begin{array}{c}0.002 \\
(0.001)\end{array}$ & & $\begin{array}{c}0.002 \\
(0.001)\end{array}$ & & $\begin{array}{c}0.002 \\
(0.001)\end{array}$ \\
\hline Observations & 2293 & 2293 & 2294 & 2293 & 2294 & 2293 \\
\hline R-squared & 0.69 & 0.80 & 0.69 & 0.80 & 0.69 & 0.80 \\
\hline
\end{tabular}


Figure 13: log per capita other revenue 1982-1985

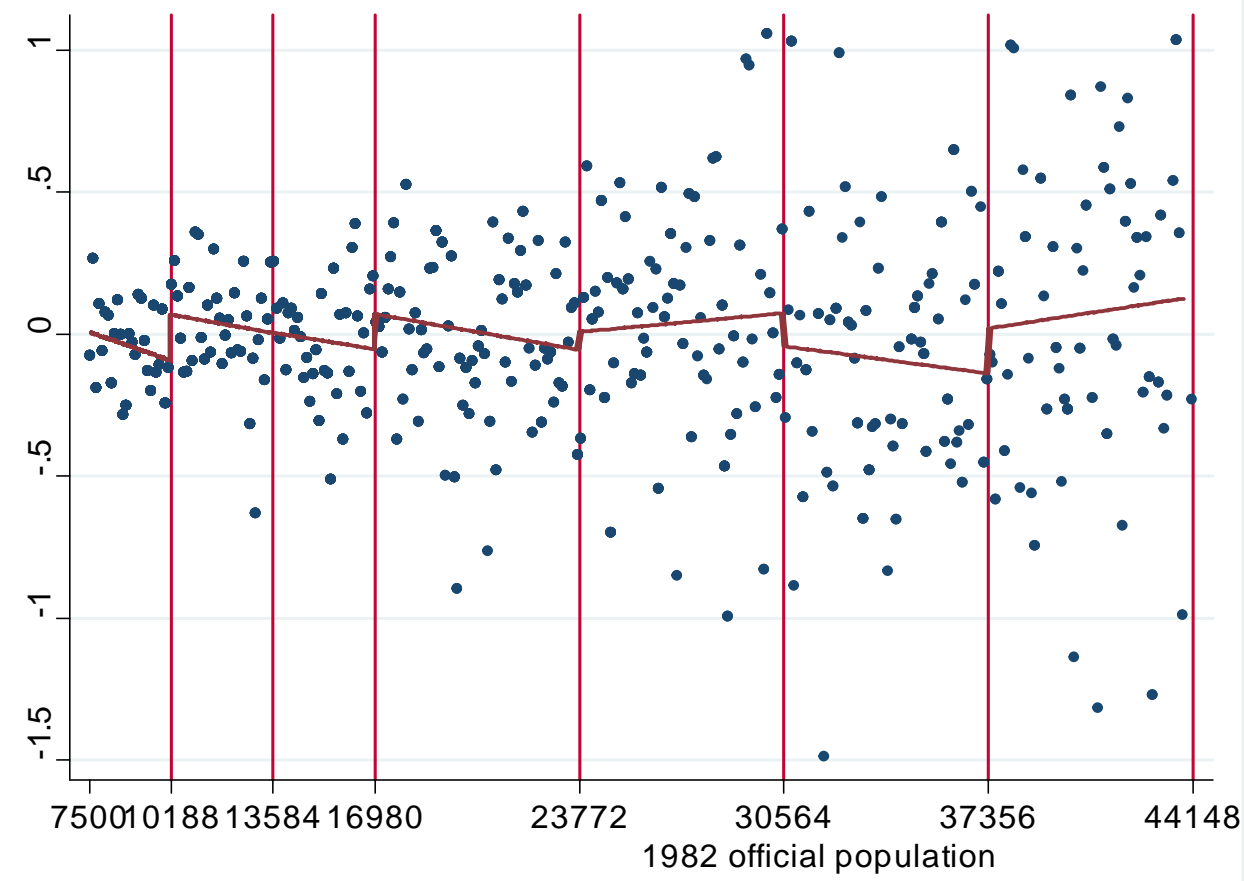

Dependent Variable: log per capita other revenue 1982-1985

\begin{tabular}{|c|c|c|c|c|c|c|}
\hline Specification: & Linear & Linear & Quadratic & Quadratic & Cubic & Cubic \\
\hline \multirow[t]{2}{*}{$\mathrm{I}[\mathrm{x}>10188]$} & 0.134 & 0.076 & 0.207 & 0.103 & 0.259 & 0.197 \\
\hline & $(0.088)$ & $(0.081)$ & $(0.128)$ & $(0.118)$ & $(0.166)$ & $(0.154)$ \\
\hline \multirow[t]{2}{*}{$\mathrm{I}[\mathrm{x}>13584]$} & -0.037 & -0.108 & 0.065 & 0.027 & 0.088 & 0.060 \\
\hline & $(0.103)$ & $(0.092)$ & $(0.145)$ & $(0.135)$ & $(0.177)$ & $(0.167)$ \\
\hline \multirow[t]{2}{*}{$\mathrm{I}[\mathrm{x}>16980]$} & 0.133 & 0.073 & 0.024 & -0.021 & 0.118 & 0.059 \\
\hline & $(0.108)$ & $(0.094)$ & $(0.145)$ & $(0.121)$ & $(0.180)$ & $(0.153)$ \\
\hline \multirow[t]{2}{*}{$\mathrm{I}[\mathrm{x}>23772]$} & -0.080 & -0.102 & -0.121 & -0.146 & -0.151 & -0.233 \\
\hline & $(0.208)$ & $(0.181)$ & $(0.236)$ & $(0.204)$ & $(0.310)$ & $(0.262)$ \\
\hline \multirow[t]{2}{*}{$\mathrm{I}[\mathrm{x}>30564]$} & -0.116 & -0.101 & 0.122 & 0.068 & 0.330 & 0.215 \\
\hline & $(0.172)$ & $(0.140)$ & $(0.243)$ & $(0.196)$ & $(0.318)$ & $(0.255)$ \\
\hline \multirow[t]{2}{*}{$\mathrm{I}[\mathrm{x}>37356]$} & 0.165 & 0.062 & 0.033 & 0.008 & 0.300 & 0.193 \\
\hline & $(0.185)$ & $(0.140)$ & $(0.270)$ & $(0.216)$ & $(0.319)$ & $(0.256)$ \\
\hline \multirow{2}{*}{ Schooling 1980} & & 0.108 & & 0.107 & & 0.108 \\
\hline & & $(0.046)^{* *}$ & & $(0.047)^{* *}$ & & $(0.047)^{* *}$ \\
\hline \multirow[t]{2}{*}{ Illiteracy 1980} & & -0.002 & & -0.002 & & -0.001 \\
\hline & & $(0.002)$ & & $(0.002)$ & & $(0.002)$ \\
\hline \multirow[t]{2}{*}{ Poverty 1980} & & -0.017 & & -0.017 & & -0.017 \\
\hline & & $(0.002)^{* * *}$ & & $(0.002)^{* * *}$ & & $(0.002)^{* * *}$ \\
\hline \multirow[t]{2}{*}{ Income pcap 1980} & & 0.279 & & 0.282 & & 0.281 \\
\hline & & $(0.101)^{* * *}$ & & $(0.102)^{* * *}$ & & $(0.102)^{* * *}$ \\
\hline \multirow[t]{2}{*}{ Mortality 1980} & & -0.002 & & -0.002 & & -0.002 \\
\hline & & $(0.001)^{* *}$ & & $(0.001)^{* *}$ & & $(0.001)^{* * *}$ \\
\hline Observations & 2285 & 2285 & 2286 & 2285 & 2286 & 2285 \\
\hline R-squared & 0.48 & 0.60 & 0.48 & 0.60 & 0.48 & 0.60 \\
\hline
\end{tabular}


Figure 14: log per capita total spending 1982-1985

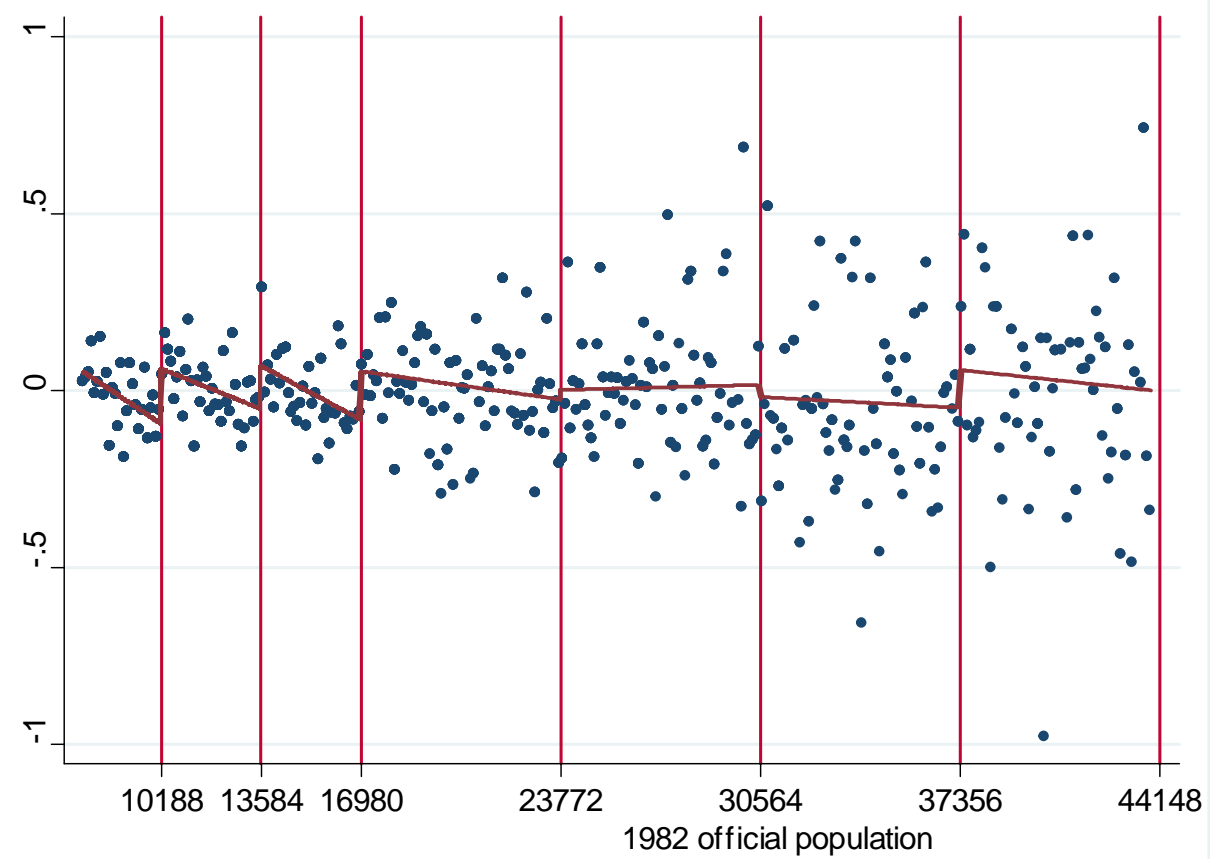

Dependent Variable: log per capita total spending 1982-1985

\begin{tabular}{|c|c|c|c|c|c|c|}
\hline Specification: & Linear & Linear & Quadratic & Quadratic & Cubic & Cubic \\
\hline $\mathrm{I}[\mathrm{x}>10188]$ & $\begin{array}{l}0.152 \\
(0.036)^{* * *}\end{array}$ & $\begin{array}{l}0.122 \\
(0.032)^{* * *}\end{array}$ & $\begin{array}{l}0.177 \\
(0.049) * * *\end{array}$ & $\begin{array}{l}0.117 \\
(0.045)^{* * *}\end{array}$ & $\begin{array}{l}0.222 \\
(0.064)^{* * *}\end{array}$ & $\begin{array}{l}0.179 \\
(0.059)^{* * *}\end{array}$ \\
\hline $\mathrm{I}[\mathrm{x}>13584]$ & $\begin{array}{l}0.119 \\
(0.049)^{* *}\end{array}$ & $\begin{array}{l}0.080 \\
(0.041)^{* *}\end{array}$ & $\begin{array}{l}0.124 \\
(0.073)^{*}\end{array}$ & $\begin{array}{l}0.108 \\
(0.062) *\end{array}$ & $\begin{array}{l}0.157 \\
(0.091)^{*}\end{array}$ & $\begin{array}{l}0.138 \\
(0.075)^{*}\end{array}$ \\
\hline $\mathrm{I}[\mathrm{x}>16980]$ & $\begin{array}{l}0.154 \\
(0.052)^{* * *}\end{array}$ & $\begin{array}{l}0.122 \\
(0.041)^{* * *}\end{array}$ & $\begin{array}{l}0.107 \\
(0.067)\end{array}$ & $\begin{array}{l}0.083 \\
(0.050)^{*}\end{array}$ & $\begin{array}{l}0.136 \\
(0.083)\end{array}$ & $\begin{array}{l}0.098 \\
(0.058)^{*}\end{array}$ \\
\hline $\mathrm{I}[\mathrm{x}>23772]$ & $\begin{array}{l}0.043 \\
(0.092)\end{array}$ & $\begin{array}{l}0.027 \\
(0.073)\end{array}$ & $\begin{array}{l}0.032 \\
(0.106)\end{array}$ & $\begin{array}{l}0.014 \\
(0.084)\end{array}$ & $\begin{array}{l}0.008 \\
(0.139)\end{array}$ & $\begin{array}{l}-0.031 \\
(0.110)\end{array}$ \\
\hline $\mathrm{I}[\mathrm{x}>30564]$ & $\begin{array}{l}-0.040 \\
(0.084)\end{array}$ & $\begin{array}{l}-0.023 \\
(0.061)\end{array}$ & $\begin{array}{l}0.063 \\
(0.126)\end{array}$ & $\begin{array}{l}0.037 \\
(0.092)\end{array}$ & $\begin{array}{l}0.188 \\
(0.165)\end{array}$ & $\begin{array}{l}0.126 \\
(0.116)\end{array}$ \\
\hline $\mathrm{I}[\mathrm{x}>37356]$ & $\begin{array}{l}0.095 \\
(0.089)\end{array}$ & $\begin{array}{l}0.029 \\
(0.062)\end{array}$ & $\begin{array}{l}0.122 \\
(0.121)\end{array}$ & $\begin{array}{l}0.090 \\
(0.079)\end{array}$ & $\begin{array}{l}0.278 \\
(0.150)^{*}\end{array}$ & $\begin{array}{l}0.193 \\
(0.095)^{* *}\end{array}$ \\
\hline Schooling 1980 & & $\begin{array}{l}0.105 \\
(0.021)^{* * *}\end{array}$ & & $\begin{array}{l}0.105 \\
(0.021)^{* * *}\end{array}$ & & $\begin{array}{l}0.105 \\
(0.021)^{* * *}\end{array}$ \\
\hline Illiteracy 1980 & & $\begin{array}{l}0.001 \\
(0.001)\end{array}$ & & $\begin{array}{l}0.001 \\
(0.001)\end{array}$ & & $\begin{array}{l}0.001 \\
(0.001)\end{array}$ \\
\hline Poverty 1980 & & $\begin{array}{l}-0.007 \\
(0.001)^{* * *}\end{array}$ & & $\begin{array}{l}-0.007 \\
(0.001)^{* * *}\end{array}$ & & $\begin{array}{l}-0.007 \\
(0.001)^{* * *}\end{array}$ \\
\hline Income pcap 1980 & & $\begin{array}{l}0.269 \\
(0.048)^{* * *}\end{array}$ & & $\begin{array}{l}0.268 \\
(0.048)^{* * *}\end{array}$ & & $\begin{array}{l}0.268 \\
(0.048)^{* * * *}\end{array}$ \\
\hline Mortality 1980 & & $\begin{array}{l}0.000 \\
(0.000)\end{array}$ & & $\begin{array}{l}0.000 \\
(0.000)\end{array}$ & & $\begin{array}{l}0.000 \\
(0.000)\end{array}$ \\
\hline Observations & 2297 & 2297 & 2298 & 2297 & 2298 & 2297 \\
\hline R-squared & 0.63 & 0.75 & 0.63 & 0.75 & 0.63 & 0.75 \\
\hline
\end{tabular}


Figure 15: log per capita education spending 1982-1983

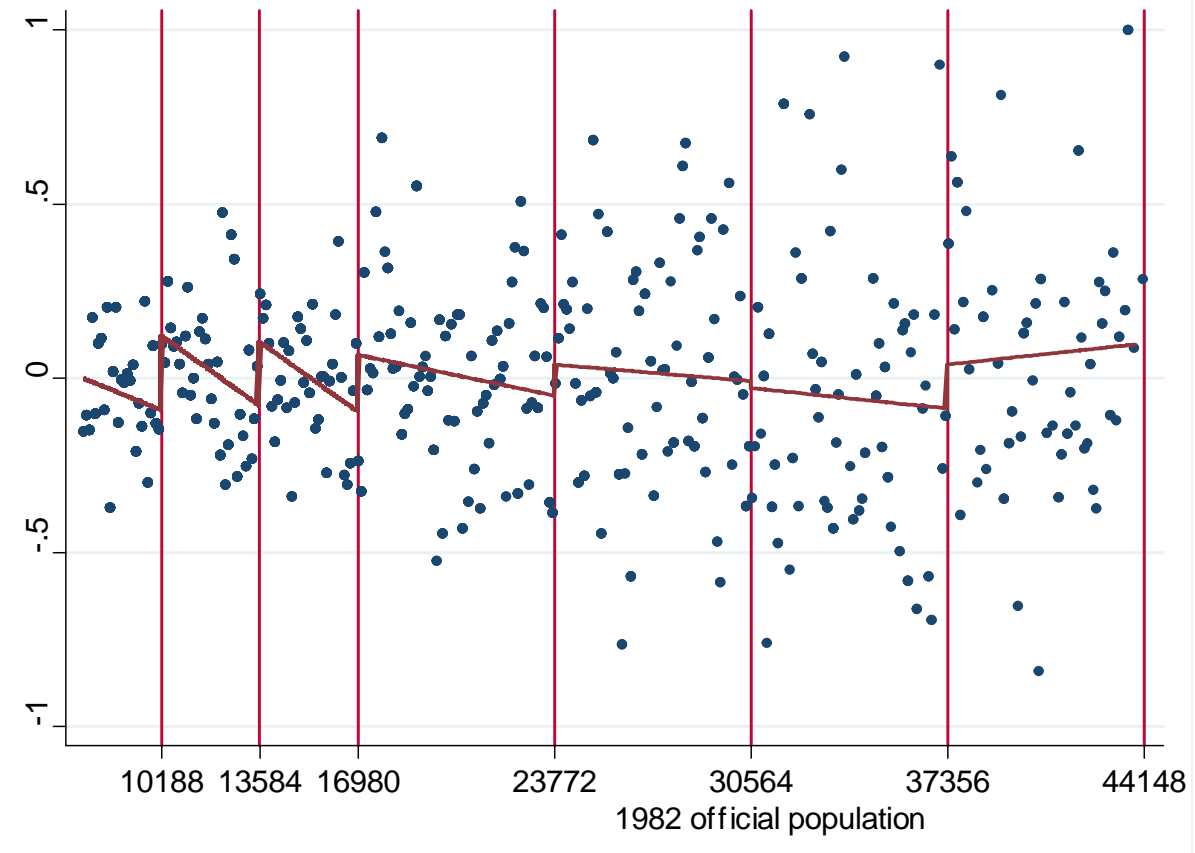

Dependent Variable: log per capita education expenditure 1982-1983

\begin{tabular}{lllllll} 
Specification: & Linear & Linear & Quadratic & Quadratic & Cubic & Cubic \\
& & & & & & \\
$\mathrm{I}[\mathrm{x}>10188]$ & 0.217 & 0.196 & 0.296 & 0.262 & 0.285 & 0.249 \\
& $(0.081)^{* * *}$ & $(0.080)^{* *}$ & $(0.118)^{* *}$ & $(0.120)^{* *}$ & $(0.157)^{*}$ & $(0.161)$ \\
$\mathrm{I}[\mathrm{x}>13584]$ & 0.206 & 0.212 & 0.267 & 0.316 & 0.388 & 0.422 \\
& $(0.087)^{* *}$ & $(0.084)^{* *}$ & $(0.129)^{* *}$ & $(0.124)^{* *}$ & $(0.165)^{* *}$ & $(0.159)^{* * *}$ \\
$\mathrm{I}[\mathrm{x}>16980]$ & 0.210 & 0.200 & 0.181 & 0.147 & 0.242 & 0.202 \\
& $(0.100)^{* *}$ & $(0.095)^{* *}$ & $(0.139)$ & $(0.132)$ & $(0.170)$ & $(0.165)$ \\
$\mathrm{I}[\mathrm{x}>23772]$ & 0.171 & 0.108 & 0.137 & 0.067 & 0.091 & 0.031 \\
& $(0.099)^{*}$ & $(0.092)$ & $(0.134)$ & $(0.123)$ & $(0.186)$ & $(0.164)$ \\
$\mathrm{I}[\mathrm{x}>30564]$ & -0.035 & -0.051 & -0.062 & -0.106 & 0.031 & -0.011 \\
& $(0.124)$ & $(0.115)$ & $(0.172)$ & $(0.160)$ & $(0.217)$ & $(0.200)$ \\
$\mathrm{I}[\mathrm{x}>37356]$ & 0.089 & 0.021 & 0.448 & 0.404 & 0.420 & 0.391 \\
& $(0.160)$ & $(0.148)$ & $(0.217)^{* *}$ & $(0.200)^{* *}$ & $(0.262)$ & $(0.242)$ \\
Schooling 1980 & & 0.003 & & 0.004 & & 0.002 \\
& & $(0.043)$ & & $(0.044)$ & & $(0.044)$ \\
Illiteracy 1980 & & -0.003 & & -0.003 & & -0.003 \\
& & $(0.002)$ & & $(0.002)$ & & $(0.002)$ \\
Poverty 1980 & & -0.003 & & -0.003 & & -0.003 \\
& & $(0.002)$ & & $(0.002)$ & & $(0.002)$ \\
Income pcap 1980 & & 0.379 & & 0.379 & & 0.379 \\
& & $(0.103)^{* * *}$ & & $(0.103)^{* * *}$ & & $(0.103)^{* * *}$ \\
Mortality 1980 & & -0.001 & & -0.001 & & -0.001 \\
& & $(0.001)$ & & $(0.001)$ & & $(0.001)$ \\
Observations & 1573 & 1573 & 1574 & 1573 & 1574 & 1573 \\
R-squared & 0.41 & 0.45 & 0.41 & 0.46 & 0.42 & 0.46 \\
& & & & & \\
\hline
\end{tabular}


Figure 16: log per capita transportation expenditure 1982-1983

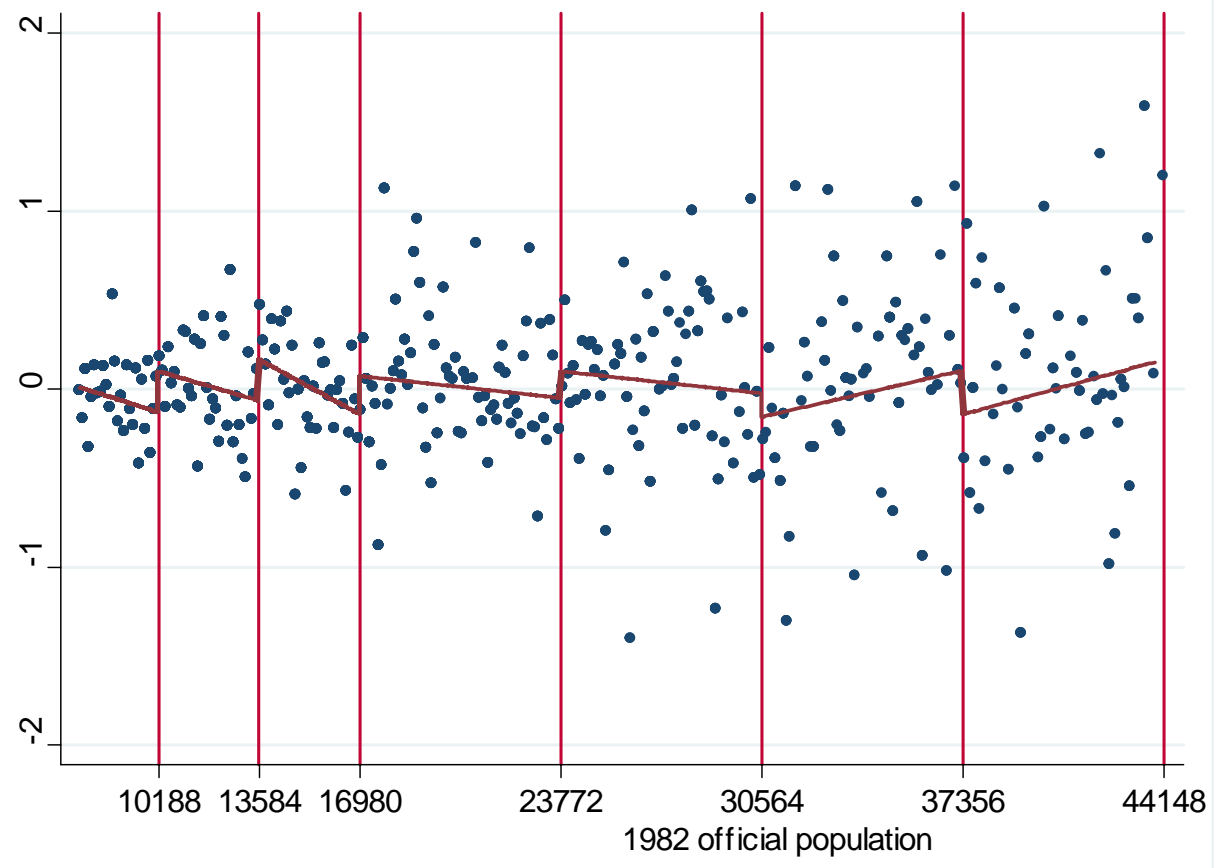

Dependent Variable: log per capita transportation expenditure 1982-1983

\begin{tabular}{lcccccc} 
Specification: & Linear & Linear & Quadratic & Quadratic & Cubic & Cubic \\
& & & & & & \\
I[x>10188] & 0.192 & 0.188 & 0.250 & 0.230 & 0.212 & 0.195 \\
& $(0.122)$ & $(0.121)$ & $(0.181)$ & $(0.182)$ & $(0.229)$ & $(0.234)$ \\
I[x>13584] & 0.196 & 0.223 & 0.337 & 0.375 & 0.371 & 0.413 \\
& $(0.126)$ & $(0.126)^{*}$ & $(0.165)^{* *}$ & $(0.165)^{* *}$ & $(0.196)^{*}$ & $(0.194)^{* *}$ \\
I[x>16980] & 0.237 & 0.270 & 0.019 & 0.041 & -0.083 & -0.063 \\
& $(0.130)^{*}$ & $(0.132)^{* *}$ & $(0.183)$ & $(0.187)$ & $(0.230)$ & $(0.241)$ \\
I[x>23772] & 0.080 & 0.115 & 0.127 & 0.176 & -0.003 & 0.051 \\
& $(0.291)$ & $(0.290)$ & $(0.319)$ & $(0.319)$ & $(0.398)$ & $(0.397)$ \\
I[x>30564] & -0.138 & -0.114 & -0.055 & -0.043 & -0.078 & -0.040 \\
& $(0.195)$ & $(0.194)$ & $(0.263)$ & $(0.259)$ & $(0.341)$ & $(0.332)$ \\
I[x>37356] & -0.329 & -0.303 & 0.023 & 0.062 & -0.237 & -0.175 \\
& $(0.252)$ & $(0.249)$ & $(0.338)$ & $(0.331)$ & $(0.364)$ & $(0.357)$ \\
Schooling 1980 & & -0.240 & & -0.241 & & -0.246 \\
& & $(0.061)^{* * *}$ & & $(0.061)^{* * *}$ & & $(0.061)^{* * *}$ \\
Illiteracy 1980 & & -0.004 & & -0.004 & & -0.004 \\
& & $(0.003)$ & & $(0.003)$ & & $(0.003)$ \\
Poverty 1980 & & -0.002 & & -0.003 & & -0.002 \\
& & $(0.003)$ & & $(0.003)$ & & $(0.003)$ \\
Income pcap 1980 & & 0.266 & & 0.264 & & 0.271 \\
& & $(0.142)^{*}$ & & $(0.141)^{*}$ & & $(0.142)^{*}$ \\
Mortality 1980 & & -0.002 & & -0.002 & & -0.002 \\
& & $(0.001)^{*}$ & & $(0.001)^{*}$ & & $(0.001)^{*}$ \\
Observations & 1532 & 1531 & 1532 & 1531 & 1532 & 1531 \\
R-squared & 0.66 & 0.66 & 0.66 & 0.66 & 0.66 & 0.67 \\
& & & & & \\
\hline & & & & &
\end{tabular}


Figure 17: log per capita housing expenditure 1982-1983

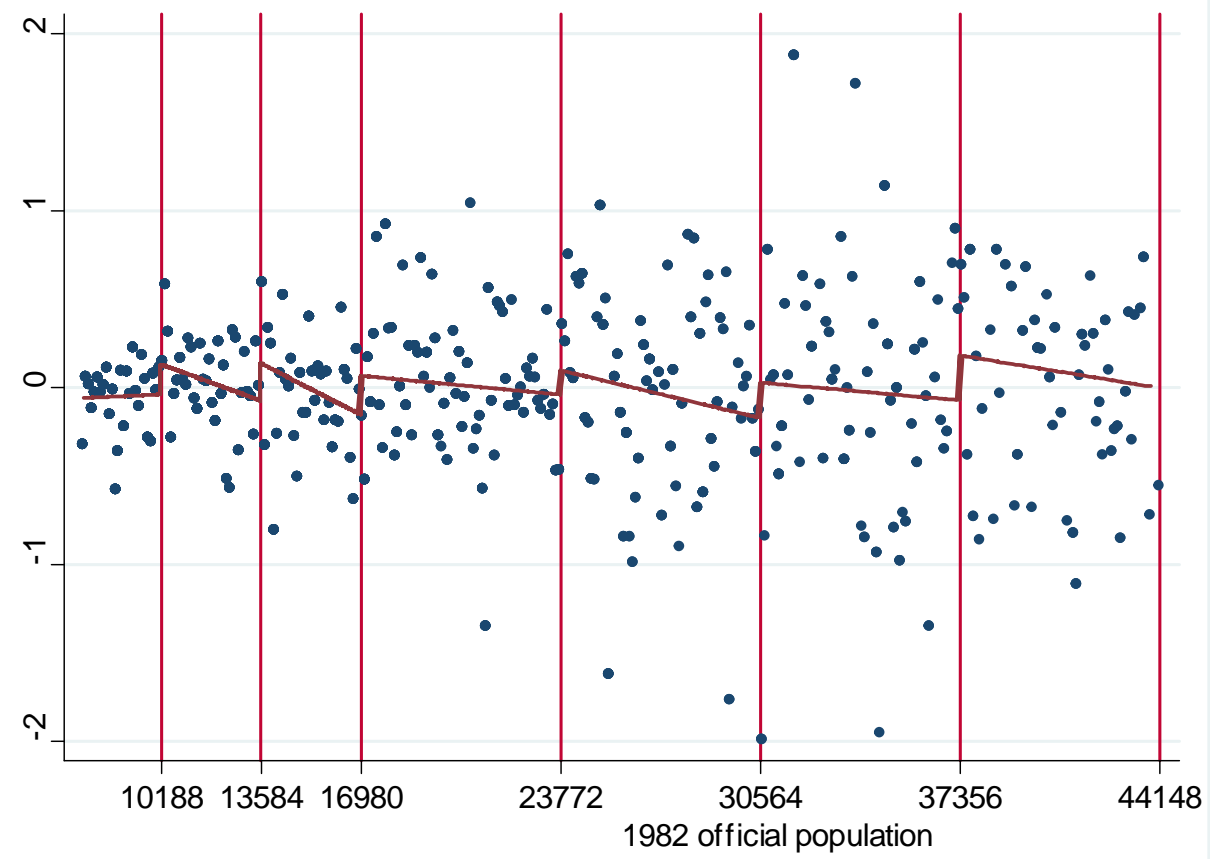

Dependent Variable: log per capita housing expenditure 1982-1983

\begin{tabular}{|c|c|c|c|c|c|c|}
\hline $\mathrm{I}[\mathrm{x}>10188]$ & $\begin{array}{l}0.161 \\
(0.125)\end{array}$ & $\begin{array}{l}0.137 \\
(0.112)\end{array}$ & $\begin{array}{l}0.255 \\
(0.185)\end{array}$ & $\begin{array}{l}0.192 \\
(0.169)\end{array}$ & $\begin{array}{l}0.318 \\
(0.240)\end{array}$ & $\begin{array}{l}0.261 \\
(0.227)\end{array}$ \\
\hline $\mathrm{I}[\mathrm{x}>13584]$ & $\begin{array}{l}0.232 \\
(0.155)\end{array}$ & $\begin{array}{l}0.226 \\
(0.143)\end{array}$ & $\begin{array}{l}0.285 \\
(0.227)\end{array}$ & $\begin{array}{l}0.374 \\
(0.208)^{*}\end{array}$ & $\begin{array}{l}0.381 \\
(0.261)\end{array}$ & $\begin{array}{l}0.438 \\
(0.244)^{*}\end{array}$ \\
\hline $\mathrm{I}[\mathrm{x}>16980]$ & $\begin{array}{l}0.269 \\
(0.154)^{*}\end{array}$ & $\begin{array}{l}0.214 \\
(0.141)\end{array}$ & $\begin{array}{l}0.097 \\
(0.211)\end{array}$ & $\begin{array}{l}0.009 \\
(0.195)\end{array}$ & $\begin{array}{l}0.150 \\
(0.274)\end{array}$ & $\begin{array}{l}0.048 \\
(0.256)\end{array}$ \\
\hline $\mathrm{I}[\mathrm{x}>23772]$ & $\begin{array}{l}0.292 \\
(0.293)\end{array}$ & $\begin{array}{l}0.247 \\
(0.269)\end{array}$ & $\begin{array}{l}0.511 \\
(0.325)\end{array}$ & $\begin{array}{l}0.479 \\
(0.294)\end{array}$ & $\begin{array}{l}0.404 \\
(0.442)\end{array}$ & $\begin{array}{l}0.438 \\
(0.394)\end{array}$ \\
\hline $\mathrm{I}[\mathrm{x}>30564]$ & $\begin{array}{l}0.070 \\
(0.229)\end{array}$ & $\begin{array}{l}0.011 \\
(0.198)\end{array}$ & $\begin{array}{l}-0.001 \\
(0.325)\end{array}$ & $\begin{array}{l}-0.108 \\
(0.281)\end{array}$ & $\begin{array}{l}-0.187 \\
(0.424)\end{array}$ & $\begin{array}{l}-0.325 \\
(0.363)\end{array}$ \\
\hline $\mathrm{I}[\mathrm{x}>37356]$ & $\begin{array}{l}0.069 \\
(0.229)\end{array}$ & $\begin{array}{l}-0.102 \\
(0.198)\end{array}$ & $\begin{array}{l}0.205 \\
(0.312)\end{array}$ & $\begin{array}{l}0.069 \\
(0.265)\end{array}$ & $\begin{array}{l}-0.207 \\
(0.389)\end{array}$ & $\begin{array}{l}-0.337 \\
(0.321)\end{array}$ \\
\hline Schooling 1980 & & $\begin{array}{l}0.325 \\
(0.061) * * *\end{array}$ & & $\begin{array}{l}0.326 \\
(0.061)^{* * *}\end{array}$ & & $\begin{array}{l}0.326 \\
(0.061)^{* * *}\end{array}$ \\
\hline Illiteracy 1980 & & $\begin{array}{l}0.007 \\
(0.003) * *\end{array}$ & & $\begin{array}{l}0.007 \\
(0.003)^{* *}\end{array}$ & & $\begin{array}{l}0.007 \\
(0.003)^{* *}\end{array}$ \\
\hline Poverty 1980 & & $\begin{array}{l}-0.009 \\
(0.003) * * *\end{array}$ & & $\begin{array}{l}-0.009 \\
(0.003)^{* * *}\end{array}$ & & $\begin{array}{l}-0.009 \\
(0.003)^{* * *}\end{array}$ \\
\hline Income pcap 1980 & & $\begin{array}{l}0.564 \\
(0.150)^{* * *}\end{array}$ & & $\begin{array}{l}0.572 \\
(0.149)^{* * *}\end{array}$ & & $\begin{array}{l}0.573 \\
(0.150)^{* * *}\end{array}$ \\
\hline Mortality 1980 & & $\begin{array}{l}0.001 \\
(0.001)\end{array}$ & & $\begin{array}{l}0.001 \\
(0.001)\end{array}$ & & $\begin{array}{l}0.001 \\
(0.001)\end{array}$ \\
\hline Observations & 1545 & 1544 & 1545 & 1544 & 1545 & 1544 \\
\hline R-squared & 0.34 & 0.45 & 0.34 & 0.46 & 0.34 & 0.46 \\
\hline
\end{tabular}


Figure 18: log per capita administration expenditure 1982-1983

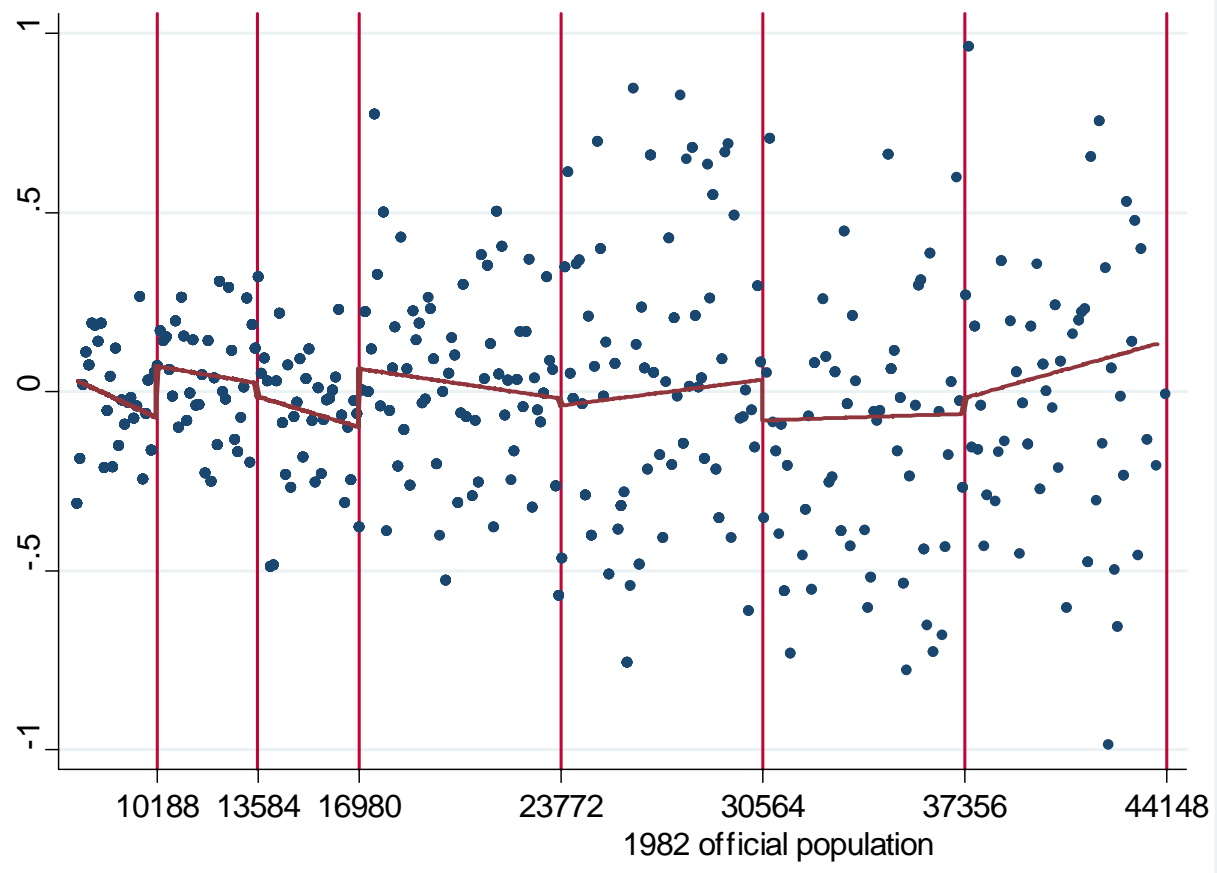

Dependent Variable: log per capita administration expenditure 1982-1983

\begin{tabular}{|c|c|c|c|c|c|c|}
\hline Specification: & Linear & Linear & Quadratic & Quadratic & Cubic & Cubic \\
\hline $\mathrm{I}[\mathrm{x}>10188]$ & $\begin{array}{c}0.125 \\
(0.081)\end{array}$ & $\begin{array}{c}0.112 \\
(0.076)\end{array}$ & $\begin{array}{c}0.255 \\
(0.114)^{* *}\end{array}$ & $\begin{array}{c}0.217 \\
(0.108)^{* *}\end{array}$ & $\begin{array}{c}0.095 \\
(0.145)\end{array}$ & $\begin{array}{c}0.046 \\
(0.138)\end{array}$ \\
\hline $\mathrm{I}[\mathrm{x}>13584]$ & $\begin{array}{l}-0.054 \\
(0.099)\end{array}$ & $\begin{array}{l}-0.052 \\
(0.090)\end{array}$ & $\begin{array}{l}-0.092 \\
(0.134)\end{array}$ & $\begin{array}{l}-0.031 \\
(0.118)\end{array}$ & $\begin{array}{c}0.025 \\
(0.150)\end{array}$ & $\begin{array}{c}0.069 \\
(0.128)\end{array}$ \\
\hline $\mathrm{I}[\mathrm{x}>16980]$ & $\begin{array}{c}0.212 \\
(0.110)^{*}\end{array}$ & $\begin{array}{c}0.201 \\
(0.099)^{* *}\end{array}$ & $\begin{array}{c}0.173 \\
(0.144)\end{array}$ & $\begin{array}{c}0.139 \\
(0.130)\end{array}$ & $\begin{array}{c}0.359 \\
(0.174)^{* *}\end{array}$ & $\begin{array}{c}0.339 \\
(0.159)^{* *}\end{array}$ \\
\hline $\mathrm{I}[\mathrm{x}>23772]$ & $\begin{array}{c}0.047 \\
(0.213)\end{array}$ & $\begin{array}{c}0.019 \\
(0.200)\end{array}$ & $\begin{array}{c}0.115 \\
(0.243)\end{array}$ & $\begin{array}{c}0.098 \\
(0.225)\end{array}$ & $\begin{array}{c}0.032 \\
(0.330)\end{array}$ & $\begin{array}{c}0.064 \\
(0.307)\end{array}$ \\
\hline $\mathrm{I}[\mathrm{x}>30564]$ & $\begin{array}{l}-0.076 \\
(0.155)\end{array}$ & $\begin{array}{l}-0.103 \\
(0.144)\end{array}$ & $\begin{array}{l}-0.106 \\
(0.221)\end{array}$ & $\begin{array}{l}-0.162 \\
(0.211)\end{array}$ & $\begin{array}{c}0.233 \\
(0.282)\end{array}$ & $\begin{array}{c}0.173 \\
(0.271)\end{array}$ \\
\hline $\mathrm{I}[\mathrm{x}>37356]$ & $\begin{array}{c}0.007 \\
(0.158)\end{array}$ & $\begin{array}{l}-0.079 \\
(0.140)\end{array}$ & $\begin{array}{c}0.198 \\
(0.220)\end{array}$ & $\begin{array}{c}0.136 \\
(0.187)\end{array}$ & $\begin{array}{c}0.300 \\
(0.287)\end{array}$ & $\begin{array}{c}0.243 \\
(0.243)\end{array}$ \\
\hline Schooling 1980 & & $\begin{array}{c}0.144 \\
(0.045)^{* * *}\end{array}$ & & $\begin{array}{c}0.145 \\
(0.045)^{* * *}\end{array}$ & & $\begin{array}{c}0.141 \\
(0.046) * * *\end{array}$ \\
\hline Illiteracy 1980 & & $\begin{array}{c}0.006 \\
(0.002)^{* * *}\end{array}$ & & $\begin{array}{c}0.006 \\
(0.002)^{* * *}\end{array}$ & & $\begin{array}{c}0.006 \\
(0.002)^{* * *}\end{array}$ \\
\hline Poverty 1980 & & $\begin{array}{c}-0.006 \\
(0.002)^{* * *}\end{array}$ & & $\begin{array}{c}-0.006 \\
(0.002)^{* * *}\end{array}$ & & $\begin{array}{c}-0.006 \\
(0.002) * * *\end{array}$ \\
\hline Income pcap 1980 & & $\begin{array}{c}0.428 \\
(0.105)^{* * *}\end{array}$ & & $\begin{array}{c}0.427 \\
(0.104)^{* * *}\end{array}$ & & $\begin{array}{c}0.426 \\
(0.104) * * *\end{array}$ \\
\hline Mortality 1980 & & $\begin{array}{c}0.001 \\
(0.001)\end{array}$ & & $\begin{array}{c}0.000 \\
(0.001)\end{array}$ & & $\begin{array}{c}0.001 \\
(0.001)\end{array}$ \\
\hline Observations & 1575 & 1574 & 1575 & 1574 & 1575 & 1574 \\
\hline R-squared & 0.46 & 0.52 & 0.46 & 0.52 & 0.46 & 0.53 \\
\hline
\end{tabular}


Figure 19: Primary school teacher-student ratio 1991

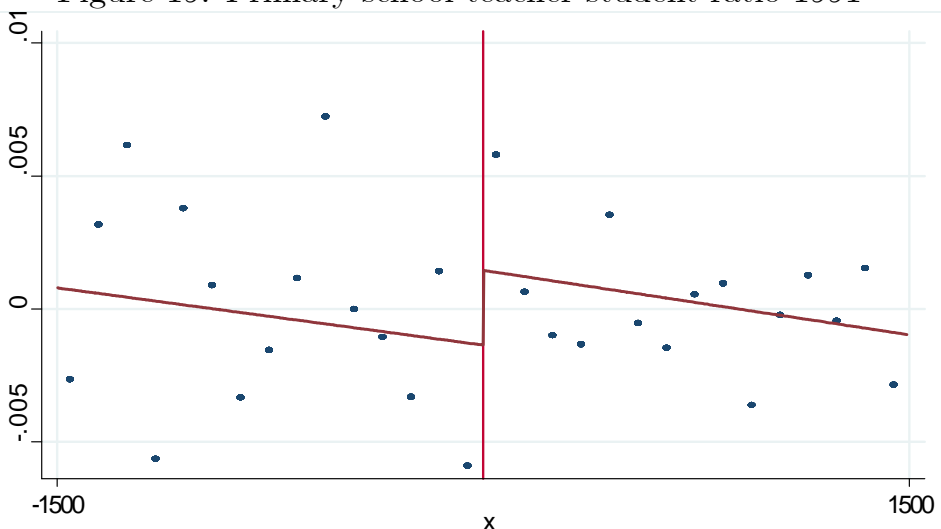

Dependent Variable: primary school teacher-student ratio in 1991

\begin{tabular}{|c|c|c|c|c|c|c|c|}
\hline Specification: & Linear & Linear & Linear & Linear & Linear & Linear & Quartic \\
\hline Neighborhood (\%): & 2 & 2 & 3 & 3 & 4 & 4 & 15 \\
\hline Pre-treatment Covariates: & $\mathrm{N}$ & $\mathrm{Y}$ & $\mathrm{N}$ & $\mathrm{Y}$ & $\mathrm{N}$ & $\mathrm{Y}$ & $\mathrm{Y}$ \\
\hline \multicolumn{8}{|l|}{$\underline{\text { Pooled Thresholds 1-3 }}$} \\
\hline $\mathrm{I}[\mathrm{x}>0]$ & $\begin{array}{c}0.012 * * \\
(0.005)\end{array}$ & $\begin{array}{c}0.010^{* *} \\
(0.005)\end{array}$ & $\begin{array}{c}0.009 * * \\
(0.004)\end{array}$ & $\begin{array}{c}0.007^{*} \\
(0.004)\end{array}$ & $\begin{array}{c}0.008 * * \\
(0.004)\end{array}$ & $\begin{array}{l}0.006^{*} \\
(0.003)\end{array}$ & $\begin{array}{c}0.012 * * * \\
(0.005)\end{array}$ \\
\hline Observations & 173 & 170 & 259 & 256 & 340 & 336 & 1098 \\
\hline R-squared & 0.45 & 0.53 & 0.44 & 0.52 & 0.42 & 0.50 & 0.48 \\
\hline \multicolumn{8}{|l|}{ Pooled Thresholds 1-2 } \\
\hline $\mathrm{I}[\mathrm{x}>0]$ & $\begin{array}{c}0.012 * * \\
(0.005)\end{array}$ & $\begin{array}{c}0.012 * * \\
(0.006)\end{array}$ & $\begin{array}{l}0.008 * \\
(0.005)\end{array}$ & $\begin{array}{c}0.010 * * \\
(0.005)\end{array}$ & $\begin{array}{c}0.006 \\
(0.004)\end{array}$ & $\begin{array}{c}0.006 \\
(0.004)\end{array}$ & $\begin{array}{c}0.007 \\
(0.005)\end{array}$ \\
\hline Observations & 112 & 111 & 177 & 176 & 232 & 230 & 753 \\
\hline R-squared & 0.45 & 0.56 & 0.45 & 0.53 & 0.41 & 0.48 & 0.47 \\
\hline \multicolumn{8}{|l|}{$1^{\text {st }}$ Threshold } \\
\hline $\mathrm{I}[\mathrm{pop}>10188]$ & $\begin{array}{c}0.009 \\
(0.013)\end{array}$ & $\begin{array}{c}0.011 \\
(0.014)\end{array}$ & $\begin{array}{c}0.015 \\
(0.010)\end{array}$ & $\begin{array}{c}0.014 \\
(0.008)\end{array}$ & $\begin{array}{c}0.011 \\
(0.008)\end{array}$ & $\begin{array}{l}0.011^{*} \\
(0.006)\end{array}$ & $\begin{array}{c}0.016 * * \\
(0.008)\end{array}$ \\
\hline Observations & 54 & 53 & 89 & 88 & 122 & 120 & 411 \\
\hline R-squared & 0.37 & 0.71 & 0.36 & 0.56 & 0.36 & 0.50 & 0.46 \\
\hline \multicolumn{8}{|l|}{$\underline{2^{\text {nd }} \text { Threshold }}$} \\
\hline $\mathrm{I}[\mathrm{pop}>13584]$ & $\begin{array}{c}0.015 \\
(0.010)\end{array}$ & $\begin{array}{c}0.019 \\
(0.012)\end{array}$ & $\begin{array}{c}0.004 \\
(0.007)\end{array}$ & $\begin{array}{c}0.011 \\
(0.007)\end{array}$ & $\begin{array}{c}0.002 \\
(0.006)\end{array}$ & $\begin{array}{c}0.002 \\
(0.006)\end{array}$ & $\begin{array}{c}0.005 \\
(0.005)\end{array}$ \\
\hline Observations & 58 & 58 & 88 & 88 & 110 & 110 & 342 \\
\hline R-squared & 0.57 & 0.65 & 0.59 & 0.67 & 0.56 & 0.62 & 0.49 \\
\hline \multicolumn{8}{|l|}{$\underline{3}^{\text {rd }}$ Threshold } \\
\hline $\mathrm{I}[\mathrm{pop}>16980]$ & $\begin{array}{l}0.019 * \\
(0.010)\end{array}$ & $\begin{array}{c}0.011 \\
(0.012)\end{array}$ & $\begin{array}{c}0.013^{*} \\
(0.008)\end{array}$ & $\begin{array}{c}0.007 \\
(0.008)\end{array}$ & $\begin{array}{c}0.013 * * \\
(0.007)\end{array}$ & $\begin{array}{c}0.009 \\
(0.006)\end{array}$ & $\begin{array}{c}0.026 * * * \\
(0.008)\end{array}$ \\
\hline Observations & 61 & 59 & 82 & 80 & 108 & 106 & 345 \\
\hline R-squared & 0.72 & 0.77 & 0.66 & 0.75 & 0.58 & 0.66 & 0.53 \\
\hline
\end{tabular}

Notes: heteroskedasticity robust standard errors in parentheses. Neighborhood (\%) is \% distance from respective cutoff. Pre-treatment covariates (1980 census) include county income per capita, average years of schooling for individuals 25 years and older, poverty headcount ratio, illiterate percentage of over 15 year olds, infant mortality, enrollment of 7 to 14 year olds and percent of population living in urban areas. All specifications allow for differential slopes and curvature by segment and relative to the thresholds. 
Figure 20: Number of municipal elemenatry schools in 1991

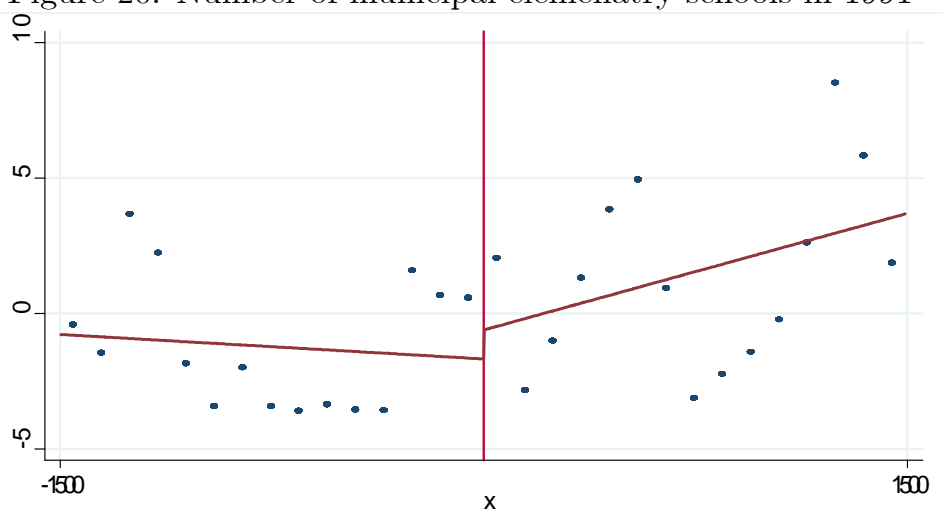

Dependent Variable: number of municipal elementary schools in 1991

\begin{tabular}{|c|c|c|c|c|c|c|c|}
\hline Specification: & Linear & Linear & Linear & Linear & Linear & Linear & Quartic \\
\hline Neighborhood (\%): & 2 & 2 & 3 & 3 & 4 & 4 & 15 \\
\hline Pre-treatment Covariates & $\mathrm{N}$ & $\mathrm{Y}$ & $\mathrm{N}$ & $\mathrm{Y}$ & $\mathrm{N}$ & $\mathrm{Y}$ & $\mathrm{Y}$ \\
\hline \multicolumn{8}{|l|}{ Pooled Thresholds 1-3 } \\
\hline $\mathrm{I}[\mathrm{x}>0]$ & $\begin{array}{c}5.163 \\
(5.800)\end{array}$ & $\begin{array}{c}4.318 \\
(5.186)\end{array}$ & $\begin{array}{c}-0.807 \\
(4.597)\end{array}$ & $\begin{array}{c}2.191 \\
(4.218)\end{array}$ & $\begin{array}{l}-2.896 \\
(4.090)\end{array}$ & $\begin{array}{l}-0.243 \\
(3.639)\end{array}$ & $\begin{array}{c}2.943 \\
(4.858)\end{array}$ \\
\hline Observations & 173 & 170 & 259 & 256 & 340 & 336 & 1100 \\
\hline R-squared & 0.50 & 0.60 & 0.51 & 0.61 & 0.51 & 0.61 & 0.60 \\
\hline \multicolumn{8}{|l|}{ Pooled Thresholds 1-2 } \\
\hline $\mathrm{I}[\mathrm{x}>0]$ & $\begin{array}{c}7.554 \\
(5.822)\end{array}$ & $\begin{array}{l}6.006 \\
(5.907)\end{array}$ & $\begin{array}{c}3.930 \\
(4.732)\end{array}$ & $\begin{array}{c}6.710 \\
(4.487)\end{array}$ & $\begin{array}{c}0.091 \\
(4.302)\end{array}$ & $\begin{array}{c}2.266 \\
(3.918)\end{array}$ & $\begin{array}{c}7.485 \\
(5.061)\end{array}$ \\
\hline Observations & 112 & 111 & 177 & 176 & 232 & 230 & 755 \\
\hline R-squared & 0.57 & 0.66 & 0.59 & 0.68 & 0.55 & 0.63 & 0.60 \\
\hline \multicolumn{8}{|l|}{$1^{\text {st }}$ Threshold } \\
\hline I[pop > 10188] & $\begin{array}{c}4.009 \\
(8.493)\end{array}$ & $\begin{array}{l}-4.409 \\
(7.054)\end{array}$ & $\begin{array}{c}1.119 \\
(6.546)\end{array}$ & $\begin{array}{c}0.779 \\
(5.661)\end{array}$ & $\begin{array}{l}-2.789 \\
(5.127)\end{array}$ & $\begin{array}{l}-2.740 \\
(4.165)\end{array}$ & $\begin{array}{c}0.214 \\
(7.147)\end{array}$ \\
\hline Observations & 54 & 53 & 89 & 88 & 122 & 120 & 412 \\
\hline R-squared & 0.65 & 0.77 & 0.64 & 0.76 & 0.62 & 0.73 & 0.63 \\
\hline \multicolumn{8}{|l|}{$2^{\text {nd }}$ Threshold } \\
\hline I[pop > 13584] & $\begin{array}{c}6.406 \\
(9.491)\end{array}$ & $\begin{array}{c}9.095 \\
(8.419)\end{array}$ & $\begin{array}{c}4.395 \\
(6.705)\end{array}$ & $\begin{array}{l}10.680 \\
(6.594)\end{array}$ & $\begin{array}{l}-1.330 \\
(6.114)\end{array}$ & $\begin{array}{c}2.983 \\
(6.204)\end{array}$ & $\begin{array}{l}7.556^{*} \\
(4.299)\end{array}$ \\
\hline Observations & 58 & 58 & 88 & 88 & 110 & 110 & 343 \\
\hline R-squared & 0.66 & 0.83 & 0.64 & 0.72 & 0.57 & 0.66 & 0.58 \\
\hline \multicolumn{8}{|l|}{$3^{\text {rd }}$ Threshold } \\
\hline I[pop > 16980] & $\begin{array}{c}8.774 \\
(16.565)\end{array}$ & $\begin{array}{c}-2.064 \\
(17.956)\end{array}$ & $\begin{array}{l}-12.409 \\
(13.440)\end{array}$ & $\begin{array}{c}-10.620 \\
(12.405)\end{array}$ & $\begin{array}{l}-11.979 \\
(11.000)\end{array}$ & $\begin{array}{l}-6.750 \\
(9.957)\end{array}$ & $\begin{array}{c}3.350 \\
(12.022)\end{array}$ \\
\hline Observations & 61 & 59 & 82 & 80 & 108 & 106 & 345 \\
\hline R-squared & 0.53 & 0.69 & 0.47 & 0.64 & 0.50 & 0.65 & 0.59 \\
\hline
\end{tabular}

Notes: heteroskedasticity robust standard errors in parentheses. Neighborhood (\%) is \% distance from respective cutoff. Pre-treatment covariates (1980 census) include county income per capita, average years of schooling for individuals 25 years and older, poverty headcount ratio, illiterate percentage of over 15 year olds, infant mortality, enrollment of 7 to 14 year olds and percent of population living in urban areas. All specifications allow for differential slopes and curvature by segment and relative to the thresholds. 
Figure 21: Years of schooling, individuals 19-28 years old in 1991

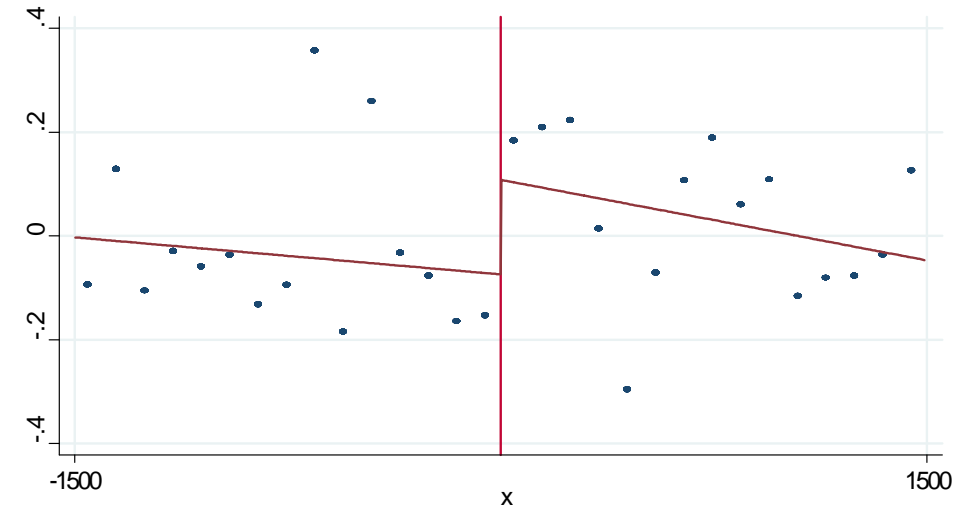

Dependent Variable: Years of schooling, individuals 19-28 years old in 1991

\begin{tabular}{|c|c|c|c|c|c|c|c|}
\hline Specification: & Linear & Linear & Linear & Linear & Linear & Linear & Quartic \\
\hline Neighborhood (\%): & 2 & 2 & 3 & 3 & 4 & 4 & 15 \\
\hline $\begin{array}{l}\text { Pre-treatment } \\
\text { Covariates: }\end{array}$ & $\mathrm{N}$ & $\mathrm{Y}$ & $\mathrm{N}$ & $\mathrm{Y}$ & $\mathrm{N}$ & $\mathrm{Y}$ & $\mathrm{Y}$ \\
\hline \multicolumn{8}{|c|}{ Pooled Thresholds 1-3 } \\
\hline $\mathrm{I}[\mathrm{x}>0]$ & $\begin{array}{c}0.330 \\
(0.260)\end{array}$ & $\begin{array}{c}0.231 \\
(0.151)\end{array}$ & $\begin{array}{c}0.527 * * * \\
(0.199)\end{array}$ & $\begin{array}{c}0.312 * * * \\
(0.114)\end{array}$ & $\begin{array}{c}0.551 * * * \\
(0.172)\end{array}$ & $\begin{array}{c}0.290 * * * \\
(0.102)\end{array}$ & $\begin{array}{c}0.356^{* *} \\
(0.140)\end{array}$ \\
\hline Observations & 200 & 197 & 293 & 290 & 386 & 382 & 1243 \\
\hline R-squared & 0.72 & 0.89 & 0.71 & 0.89 & 0.69 & 0.89 & 0.88 \\
\hline \multicolumn{8}{|c|}{ Pooled Thresholds 1-2 } \\
\hline $\mathrm{I}[\mathrm{x}>0]$ & $\begin{array}{c}0.415 \\
(0.324)\end{array}$ & $\begin{array}{c}0.191 \\
(0.180)\end{array}$ & $\begin{array}{c}0.511 * * \\
(0.243)\end{array}$ & $\begin{array}{c}0.309 * * \\
(0.140)\end{array}$ & $\begin{array}{c}0.512 * * \\
(0.215)\end{array}$ & $\begin{array}{c}0.304 * * \\
(0.129)\end{array}$ & $\begin{array}{c}0.374 * * \\
(0.179)\end{array}$ \\
\hline Observations & 131 & 130 & 200 & 199 & 259 & 257 & 857 \\
\hline R-squared & 0.74 & 0.90 & 0.74 & 0.89 & 0.71 & 0.88 & 0.87 \\
\hline \multicolumn{8}{|l|}{$\underline{1^{\text {st }} \text { Threshold }}$} \\
\hline 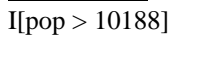 & $\begin{array}{c}0.286 \\
(0.500)\end{array}$ & $\begin{array}{c}0.557 \\
(0.484)\end{array}$ & $\begin{array}{c}0.445 \\
(0.352)\end{array}$ & $\begin{array}{c}0.439 \\
(0.302)\end{array}$ & $\begin{array}{c}0.403 \\
(0.340)\end{array}$ & $\begin{array}{l}0.424 * \\
(0.242)\end{array}$ & $\begin{array}{l}0.525^{*} \\
(0.313)\end{array}$ \\
\hline Observations & 66 & 65 & 101 & 100 & 135 & 133 & 470 \\
\hline R-squared & 0.79 & 0.91 & 0.78 & 0.89 & 0.75 & 0.89 & 0.87 \\
\hline \multicolumn{8}{|l|}{$2^{\text {nd }}$ Threshold } \\
\hline$\overline{\mathrm{I}[\mathrm{pop}>13584]}$ & $\begin{array}{c}0.398 \\
(0.530)\end{array}$ & $\begin{array}{l}0.347 * \\
(0.204)\end{array}$ & $\begin{array}{c}0.497 \\
(0.373)\end{array}$ & $\begin{array}{l}0.338^{*} \\
(0.172)\end{array}$ & $\begin{array}{l}0.585^{*} \\
(0.305)\end{array}$ & $\begin{array}{c}0.257 \\
(0.158)\end{array}$ & $\begin{array}{c}0.215 \\
(0.193)\end{array}$ \\
\hline Observations & 65 & 65 & 99 & 99 & 124 & 124 & 387 \\
\hline R-squared & 0.77 & 0.96 & 0.76 & 0.93 & 0.73 & 0.90 & 0.88 \\
\hline \multicolumn{8}{|l|}{$3^{\text {rd }}$ Threshold } \\
\hline $\bar{I}[$ pop $>16980]$ & $\begin{array}{c}0.024 \\
(0.507)\end{array}$ & $\begin{array}{c}0.403 \\
(0.333)\end{array}$ & $\begin{array}{c}0.280 \\
(0.385)\end{array}$ & $\begin{array}{c}0.185 \\
(0.224)\end{array}$ & $\begin{array}{c}0.552 \\
(0.353)\end{array}$ & $\begin{array}{c}0.169 \\
(0.192)\end{array}$ & $\begin{array}{c}0.366 \\
(0.231)\end{array}$ \\
\hline Observations & 69 & 67 & 93 & 91 & 127 & 125 & 386 \\
\hline R-squared & 0.77 & 0.94 & 0.73 & 0.93 & 0.70 & 0.92 & 0.91 \\
\hline
\end{tabular}

Notes: heteroskedasticity robust standard errors in parentheses. Neighborhood (\%) is \% distance from respective cutoff. Pre-treatment covariates (1980 census) include county income per capita, average years of schooling for individuals 25 years and older, poverty headcount ratio, illiterate percentage of over 15 year olds, infant mortality, enrollment of 7 to 14 year olds and percent of population living in urban areas. All specifications allow for differential slopes and curvature by segment and relative to the thresholds. 
Figure 22: Years of schooling, individuals 9-18 years old in 1991

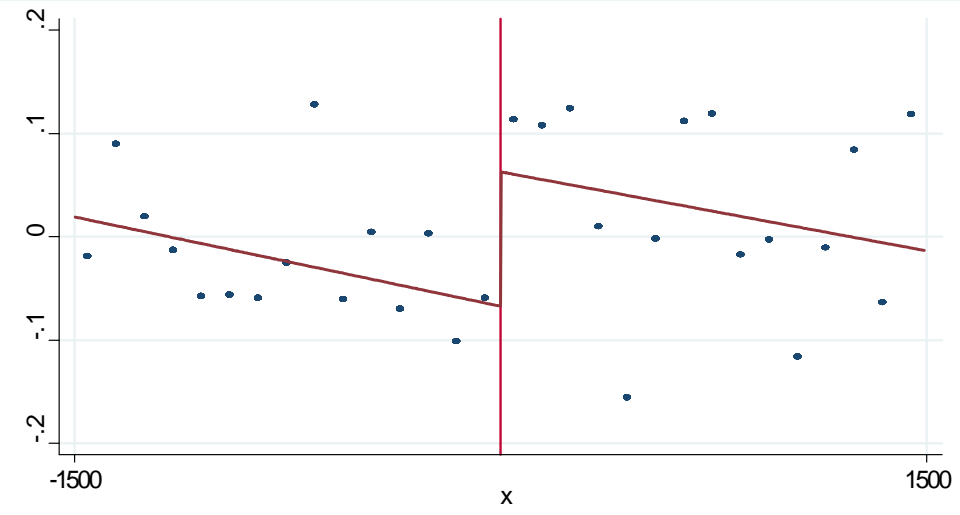

Dependent Variable: Years of schooling, individuals 9-18 years old in 1991

\begin{tabular}{|c|c|c|c|c|c|c|c|}
\hline Specification: & Linear & Linear & Linear & Linear & Linear & Linear & Quartic \\
\hline Neighborhood (\%): & 2 & 2 & 3 & 3 & 4 & 4 & 15 \\
\hline Pre-treatment Covariates: & $\mathrm{N}$ & $\mathrm{Y}$ & $\mathrm{N}$ & $\mathrm{Y}$ & $\mathrm{N}$ & $\mathrm{Y}$ & Y \\
\hline \multicolumn{8}{|l|}{$\underline{\text { Pooled Thresholds 1-3 }}$} \\
\hline $\mathrm{I}[\mathrm{x}>0]$ & $\begin{array}{c}0.211 \\
(0.157)\end{array}$ & $\begin{array}{l}0.158 * \\
(0.095)\end{array}$ & $\begin{array}{c}0.293 * * \\
(0.117)\end{array}$ & $\begin{array}{c}0.173 * * \\
(0.071)\end{array}$ & $\begin{array}{c}0.301 * * * \\
(0.099)\end{array}$ & $\begin{array}{c}0.144 * * \\
(0.062)\end{array}$ & $\begin{array}{c}0.181 * * \\
(0.082)\end{array}$ \\
\hline Observations & 200 & 197 & 293 & 290 & 386 & 382 & 1243 \\
\hline R-squared & 0.84 & 0.94 & 0.83 & 0.93 & 0.81 & 0.93 & 0.92 \\
\hline \multicolumn{8}{|l|}{ Pooled Thresholds 1-2 } \\
\hline $\mathrm{I}[\mathrm{x}>0]$ & $\begin{array}{c}0.269 \\
(0.204)\end{array}$ & $\begin{array}{c}0.175 \\
(0.120)\end{array}$ & $\begin{array}{l}0.287 * \\
(0.150)\end{array}$ & $\begin{array}{c}0.209 * * \\
(0.090)\end{array}$ & $\begin{array}{c}0.285^{* *} \\
(0.130)\end{array}$ & $\begin{array}{c}0.176 * * \\
(0.081)\end{array}$ & $\begin{array}{c}0.218 * * \\
(0.103)\end{array}$ \\
\hline Observations & 131 & 130 & 200 & 199 & 259 & 257 & 857 \\
\hline R-squared & 0.83 & 0.94 & 0.83 & 0.93 & 0.81 & 0.92 & 0.91 \\
\hline \multicolumn{8}{|l|}{$\underline{1^{\text {st }} \text { Threshold }}$} \\
\hline I[pop > 10188] & $\begin{array}{c}0.245 \\
(0.270)\end{array}$ & $\begin{array}{c}0.412 \\
(0.270)\end{array}$ & $\begin{array}{l}0.340 * \\
(0.202)\end{array}$ & $\begin{array}{c}0.352 * * \\
(0.168)\end{array}$ & $\begin{array}{c}0.268 \\
(0.189)\end{array}$ & $\begin{array}{l}0.265 * \\
(0.134)\end{array}$ & $\begin{array}{c}0.370 * * \\
(0.170)\end{array}$ \\
\hline Observations & 66 & 65 & 101 & 100 & 135 & 133 & 470 \\
\hline R-squared & 0.88 & 0.95 & 0.87 & 0.93 & 0.84 & 0.93 & 0.91 \\
\hline \multicolumn{8}{|l|}{$\underline{2^{\text {nd }} \text { Threshold }}$} \\
\hline I[pop > 13584] & $\begin{array}{c}0.298 \\
(0.311)\end{array}$ & $\begin{array}{c}0.264 \\
(0.157)\end{array}$ & $\begin{array}{c}0.255 \\
(0.224)\end{array}$ & $\begin{array}{c}0.191 \\
(0.116)\end{array}$ & $\begin{array}{c}0.307 \\
(0.191)\end{array}$ & $\begin{array}{c}0.102 \\
(0.110)\end{array}$ & $\begin{array}{c}0.115 \\
(0.082)\end{array}$ \\
\hline Observations & 65 & 65 & 99 & 99 & 124 & 124 & 387 \\
\hline R-squared & 0.84 & 0.96 & 0.84 & 0.95 & 0.81 & 0.93 & 0.91 \\
\hline \multicolumn{8}{|l|}{$3^{\text {rd }}$ Threshold } \\
\hline I[pop > 16980] & $\begin{array}{c}0.052 \\
(0.282)\end{array}$ & $\begin{array}{c}0.145 \\
(0.225)\end{array}$ & $\begin{array}{c}0.127 \\
(0.210)\end{array}$ & $\begin{array}{c}0.022 \\
(0.144)\end{array}$ & $\begin{array}{c}0.296 \\
(0.188)\end{array}$ & $\begin{array}{c}0.060 \\
(0.124)\end{array}$ & $\begin{array}{c}0.128 \\
(0.147)\end{array}$ \\
\hline Observations & 69 & 67 & 93 & 91 & 127 & 125 & 386 \\
\hline R-squared & 0.88 & 0.96 & 0.85 & 0.95 & 0.83 & 0.94 & 0.94 \\
\hline
\end{tabular}

Notes: heteroskedasticity robust standard errors in parentheses. Neighborhood (\%) is \% distance from respective cutoff. Pre-treatment covariates (1980 census) include county income per capita, average years of schooling for individuals 25 years and older, poverty headcount ratio, illiterate percentage of over 15 year olds, infant mortality, enrollment of 7 to 14 year olds and percent of population living in urban areas. All specifications allow for differential slopes and curvature by segment and relative to the thresholds. 
Figure 23: Literacy, individuals 19-28 years old in 1991

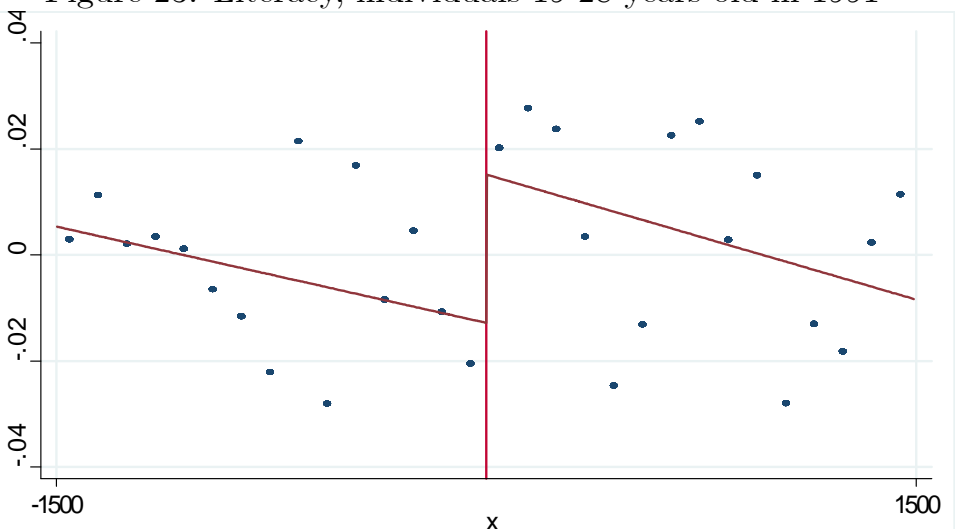

Dependent Variable: Literacy, individuals 19-28 years old in 1991

\begin{tabular}{|c|c|c|c|c|c|c|c|}
\hline Specification: & Linear & Linear & Linear & Linear & Linear & Linear & Quartic \\
\hline Neighborhood (\%): & 2 & 2 & 3 & 3 & 4 & 4 & 15 \\
\hline Pre-treatment Covariates & $\mathrm{N}$ & $\mathrm{Y}$ & $\mathrm{N}$ & $\mathrm{Y}$ & $\mathrm{N}$ & $\mathrm{Y}$ & $\mathrm{Y}$ \\
\hline \multicolumn{8}{|l|}{ Pooled Thresholds 1-3 } \\
\hline $\mathrm{I}[\mathrm{x}>0]$ & $\begin{array}{c}0.058 * * \\
(0.027)\end{array}$ & $\begin{array}{c}0.048^{*} * * \\
(0.016)\end{array}$ & $\begin{array}{c}0.064 * * * \\
(0.019)\end{array}$ & $\begin{array}{c}0.050^{* * * *} \\
(0.012)\end{array}$ & $\begin{array}{c}0.062 * * * \\
(0.016)\end{array}$ & $\begin{array}{c}0.042^{* * *} * \\
(0.011)\end{array}$ & $\begin{array}{c}0.054 \text { *** } \\
(0.014)\end{array}$ \\
\hline Observations & 200 & 197 & 293 & 290 & 386 & 382 & 1243 \\
\hline R-squared & 0.78 & 0.91 & 0.80 & 0.92 & 0.80 & 0.91 & 0.90 \\
\hline \multicolumn{8}{|l|}{ Pooled Thresholds 1-2 } \\
\hline $\mathrm{I}[\mathrm{x}>0]$ & $\begin{array}{c}0.055 \\
(0.035)\end{array}$ & $\begin{array}{c}0.044^{* *} \\
(0.019)\end{array}$ & $\begin{array}{c}0.046^{* *} \\
(0.023)\end{array}$ & $\begin{array}{c}0.047 * * * \\
(0.015)\end{array}$ & $\begin{array}{c}0.046 * * \\
(0.021)\end{array}$ & $\begin{array}{c}0.037 * * * \\
(0.014)\end{array}$ & $\begin{array}{c}0.053 * * * \\
(0.018)\end{array}$ \\
\hline Observations & 131 & 130 & 200 & 199 & 259 & 257 & 857 \\
\hline R-squared & 0.79 & 0.93 & 0.83 & 0.93 & 0.81 & 0.91 & 0.90 \\
\hline \multicolumn{8}{|l|}{$\underline{1^{\text {st }} \text { Threshold }}$} \\
\hline 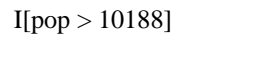 & $\begin{array}{c}0.059 \\
(0.059)\end{array}$ & $\begin{array}{c}0.066^{*} \\
(0.037)\end{array}$ & $\begin{array}{c}0.059 \\
(0.040)\end{array}$ & $\begin{array}{c}0.076^{* * * *} \\
(0.026)\end{array}$ & $\begin{array}{c}0.042 \\
(0.039)\end{array}$ & $\begin{array}{l}0.048 * \\
(0.024)\end{array}$ & $\begin{array}{c}0.073 * * \\
(0.031)\end{array}$ \\
\hline Observations & 66 & 65 & 101 & 100 & 135 & 133 & 470 \\
\hline R-squared & 0.83 & 0.95 & 0.84 & 0.94 & 0.82 & 0.93 & 0.90 \\
\hline \multicolumn{8}{|l|}{$\underline{2}^{\text {nd }}$ Threshold } \\
\hline$\overline{\mathrm{I}[\mathrm{pop}>13584]}$ & $\begin{array}{c}0.044 \\
(0.040)\end{array}$ & $\begin{array}{c}0.031 \\
(0.023)\end{array}$ & $\begin{array}{c}0.036 \\
(0.028)\end{array}$ & $\begin{array}{c}0.022 \\
(0.015)\end{array}$ & $\begin{array}{c}0.052 * * \\
(0.023)\end{array}$ & $\begin{array}{l}0.027 * \\
(0.015)\end{array}$ & $\begin{array}{c}0.029 * * \\
(0.013)\end{array}$ \\
\hline Observations & 65 & 65 & 99 & 99 & 124 & 124 & 387 \\
\hline R-squared & 0.82 & 0.95 & 0.85 & 0.93 & 0.86 & 0.93 & 0.90 \\
\hline \multicolumn{8}{|l|}{$3^{\text {rd }}$ Threshold } \\
\hline I[pop > 16980] & $\begin{array}{c}0.044 \\
(0.044)\end{array}$ & $\begin{array}{c}0.042 \\
(0.030)\end{array}$ & $\begin{array}{l}0.065^{*} \\
(0.036)\end{array}$ & $\begin{array}{c}0.042 \\
(0.026)\end{array}$ & $\begin{array}{c}0.073 * * \\
(0.031)\end{array}$ & $\begin{array}{c}0.030 \\
(0.020)\end{array}$ & $\begin{array}{c}0.058 * * * \\
(0.021)\end{array}$ \\
\hline Observations & 69 & 67 & 93 & 91 & 127 & 125 & 386 \\
\hline R-squared & 0.86 & 0.95 & 0.84 & 0.94 & 0.82 & 0.94 & 0.92 \\
\hline
\end{tabular}

Notes: heteroskedasticity robust standard errors in parentheses. Neighborhood (\%) is \% distance from respective cutoff. Pre-treatment covariates (1980 census) include county income per capita, average years of schooling for individuals 25 years and older, poverty headcount ratio, illiterate percentage of over 15 year olds, infant mortality, enrollment of 7 to 14 year olds and percent of population living in urban areas. All specifications allow for differential slopes and curvature by segment and relative to the thresholds. 
Figure 24: Literacy, individuals 9-18 years old in 1991

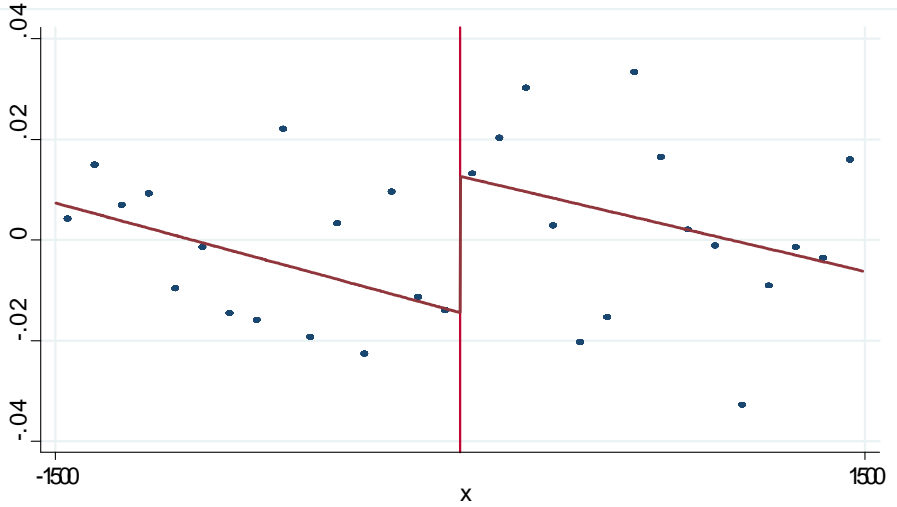

Dependent Variable: Literacy, individuals 9-18 years old in 1991

\begin{tabular}{|c|c|c|c|c|c|c|c|}
\hline Specification: & Linear & Linear & Linear & Linear & Linear & Linear & Quartic \\
\hline Neighborhood (\%): & 2 & 2 & 3 & 3 & 4 & 4 & 15 \\
\hline Pre-treatment Covariates: & $\mathrm{N}$ & $\mathrm{Y}$ & $\mathrm{N}$ & $\mathrm{Y}$ & $\mathrm{N}$ & $\mathrm{Y}$ & $\mathrm{Y}$ \\
\hline \multicolumn{8}{|l|}{ Pooled Thresholds 1-3 } \\
\hline $\mathrm{I}[\mathrm{x}>0]$ & $\begin{array}{c}0.038 \\
(0.028)\end{array}$ & $\begin{array}{c}0.028 \\
(0.019)\end{array}$ & $\begin{array}{c}0.043 * * \\
(0.020)\end{array}$ & $\begin{array}{l}0.027 * \\
(0.014)\end{array}$ & $\begin{array}{c}0.048 * * * \\
(0.017)\end{array}$ & $\begin{array}{c}0.026 * * \\
(0.012)\end{array}$ & $\begin{array}{c}0.032 * * \\
(0.016)\end{array}$ \\
\hline Observations & 200 & 197 & 293 & 290 & 386 & 382 & 1243 \\
\hline R-squared & 0.82 & 0.93 & 0.83 & 0.91 & 0.82 & 0.91 & 0.90 \\
\hline \multicolumn{8}{|l|}{$\underline{\text { Pooled Thresholds 1-2 }}$} \\
\hline $\mathrm{I}[\mathrm{x}>0]$ & $\begin{array}{c}0.050 \\
(0.037)\end{array}$ & $\begin{array}{c}0.036 \\
(0.023)\end{array}$ & $\begin{array}{c}0.038 \\
(0.025)\end{array}$ & $\begin{array}{c}0.037 * * \\
(0.017)\end{array}$ & $\begin{array}{l}0.040^{*} \\
(0.022)\end{array}$ & $\begin{array}{c}0.028 * \\
(0.016)\end{array}$ & $\begin{array}{c}0.043 * * \\
(0.019)\end{array}$ \\
\hline Observations & 131 & 130 & 200 & 199 & 259 & 257 & 857 \\
\hline R-squared & 0.82 & 0.93 & 0.84 & 0.92 & 0.82 & 0.91 & 0.90 \\
\hline \multicolumn{8}{|l|}{$\underline{1}^{\text {st }}$ Threshold } \\
\hline I[pop > 10188] & $\begin{array}{c}0.050 \\
(0.058)\end{array}$ & $\begin{array}{c}0.057 \\
(0.048)\end{array}$ & $\begin{array}{c}0.061 \\
(0.041)\end{array}$ & $\begin{array}{c}0.073 * * \\
(0.032)\end{array}$ & $\begin{array}{c}0.054 \\
(0.040)\end{array}$ & $\begin{array}{c}0.059 * * \\
(0.026)\end{array}$ & $\begin{array}{c}0.073 * * \\
(0.031)\end{array}$ \\
\hline Observations & 66 & 65 & 101 & 100 & 135 & 133 & 470 \\
\hline R-squared & 0.85 & 0.94 & 0.84 & 0.92 & 0.81 & 0.91 & 0.90 \\
\hline \multicolumn{8}{|l|}{$\underline{2^{\text {nd }} \text { Threshold }}$} \\
\hline I[pop > 13584] & $\begin{array}{c}0.041 \\
(0.045)\end{array}$ & $\begin{array}{c}0.037 \\
(0.037)\end{array}$ & $\begin{array}{c}0.024 \\
(0.031)\end{array}$ & $\begin{array}{c}0.020 \\
(0.020)\end{array}$ & $\begin{array}{c}0.034 \\
(0.026)\end{array}$ & $\begin{array}{c}0.006 \\
(0.018)\end{array}$ & $\begin{array}{c}0.019 \\
(0.014)\end{array}$ \\
\hline Observations & 65 & 65 & 99 & 99 & 124 & 124 & 387 \\
\hline R-squared & 0.84 & 0.94 & 0.88 & 0.95 & 0.87 & 0.94 & 0.90 \\
\hline \multicolumn{8}{|l|}{$3^{\text {rd }}$ Threshold } \\
\hline I[pop > 16980] & $\begin{array}{c}-0.006 \\
(0.050)\end{array}$ & $\begin{array}{c}0.011 \\
(0.045)\end{array}$ & $\begin{array}{c}0.029 \\
(0.039)\end{array}$ & $\begin{array}{c}0.010 \\
(0.034)\end{array}$ & $\begin{array}{l}0.058 * \\
(0.034)\end{array}$ & $\begin{array}{c}0.015 \\
(0.026)\end{array}$ & $\begin{array}{c}0.015 \\
(0.031)\end{array}$ \\
\hline Observations & 69 & 67 & 93 & 91 & 127 & 125 & 386 \\
\hline R-squared & 0.87 & 0.94 & 0.85 & 0.93 & 0.84 & 0.93 & 0.92 \\
\hline
\end{tabular}

Notes: heteroskedasticity robust standard errors in parentheses. Neighborhood (\%) is \% distance from respective cutoff. Pre-treatment covariates (1980 census) include county income per capita, average years of schooling for individuals 25 years and older, poverty headcount ratio, illiterate percentage of over 15 year olds, infant mortality, enrollment of 7 to 14 year olds and percent of population living in urban areas. All specifications allow for differential slopes and curvature by segment and relative to the thresholds. 
Figure 25: Treatment effects by cohort age

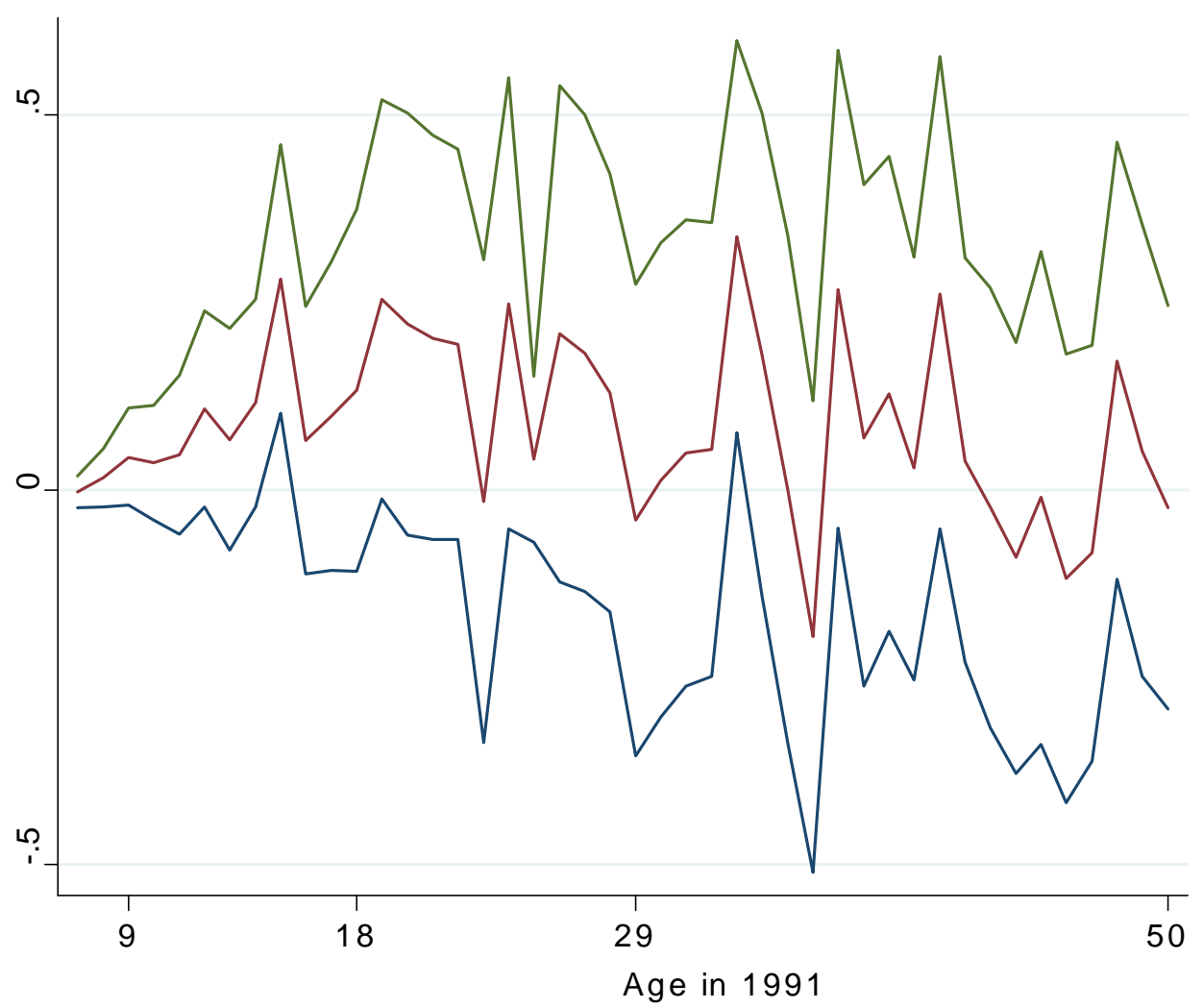


Table III: effects on schools and teacher-student ratios in southern vs. northern counties

\begin{tabular}{lccccccc}
\hline Specification: & Linear & Linear & Linear & Linear & Linear & Linear & Quartic \\
Neighborhood $(\%):$ & 2 & 2 & 3 & 3 & 4 & 4 & 15 \\
$\begin{array}{l}\text { Pre-treatment } \\
\text { Covariates: }\end{array}$ & $\mathrm{N}$ & $\mathrm{Y}$ & $\mathrm{N}$ & $\mathrm{Y}$ & $\mathrm{N}$ & $\mathrm{Y}$ & $\mathrm{Y}$
\end{tabular}

Panel A: southern counties (South, Southeast and Center-west regions)

Dependent Variable: number of municipal elementary schools in 1991

$\begin{array}{lccccccc}\mathrm{I}[\mathrm{x}>0] & -3.757 & -8.429 & -2.534 & -1.629 & -4.531 & -2.359 & -2.027 \\ & (6.176) & (5.346) & (4.862) & (4.336) & (4.272) & (3.915) & (4.964) \\ \text { Observations } & 87 & 84 & 129 & 126 & 171 & 167 & 552 \\ \text { R-squared } & 0.52 & 0.68 & 0.47 & 0.61 & 0.42 & 0.57 & 0.45\end{array}$

Dependent Variable: primary school teacher-student ratio in 1991

$\begin{array}{lccccccc}\mathrm{I}[\mathrm{X}>0] & 0.016 & 0.018^{*} & 0.013 & 0.012 * & 0.009 & 0.010^{*} & 0.018^{* *} \\ & (0.010) & (0.009) & (0.008) & (0.007) & (0.007) & (0.006) & (0.008) \\ \text { Observations } & 87 & 84 & 129 & 126 & 171 & 167 & 550 \\ \text { R-squared } & 0.45 & 0.63 & 0.41 & 0.59 & 0.32 & 0.47 & 0.41\end{array}$

$\underline{\text { Panel B: northern counties (North and Northeast regions) }}$

Dependent Variable: number of municipal elementary schools in 1991

$\begin{array}{lccccccc}\mathrm{I}[\mathrm{x}>0] & 21.374 & 13.784 & 1.946 & 2.301 & -5.324 & -3.058 & 7.844 \\ & (14.333) & (11.458) & (10.402) & (8.700) & (7.932) & (7.023) & (8.423) \\ \text { Observations } & 86 & 86 & 130 & 130 & 169 & 169 & 548 \\ \text { R-squared } & 0.53 & 0.70 & 0.43 & 0.60 & 0.44 & 0.59 & 0.51\end{array}$

Dependent Variable: primary school teacher-student ratio in 1991

$\begin{array}{lccccccc}\mathrm{I}[\mathrm{x}>0] & 0.013^{*} & 0.007 & 0.005 & 0.003 & 0.006 & 0.004 & 0.008^{*} \\ & (0.007) & (0.006) & (0.005) & (0.004) & (0.004) & (0.004) & (0.004) \\ \text { Observations } & 86 & 86 & 130 & 130 & 169 & 169 & 548 \\ \text { R-squared } & 0.57 & 0.64 & 0.55 & 0.61 & 0.58 & 0.65 & 0.42\end{array}$

Notes: heteroskedasticity robust standard errors in parentheses. Neighborhood (\%) is \% distance from respective cutoff. Pre-treatment covariates (1980 census) include county income per capita, average years of schooling for individuals 25 years and older, poverty headcount ratio, illiterate percentage of over 15 year olds, infant mortality, enrollment of 7 to 14 year olds and percent of population living in urban areas. All specifications allow for differential slopes and curvature by segment and relative to the thresholds. 
Table IV: effects on schooling and literacy in southern vs. northern counties

\begin{tabular}{|c|c|c|c|c|c|c|c|}
\hline Specification: & Linear & Linear & Linear & Linear & Linear & Linear & Quartic \\
\hline Neighborhood (\%): & 2 & 2 & 3 & 3 & 4 & 4 & 15 \\
\hline Pre-treatment Covariates: & $\mathrm{N}$ & $\mathrm{Y}$ & $\mathrm{N}$ & $\mathrm{Y}$ & $\mathrm{N}$ & $\mathrm{Y}$ & $\mathrm{Y}$ \\
\hline \multicolumn{8}{|c|}{$\underline{\text { Panel A: southern counties (South, Southeast and Center-west regions) }}$} \\
\hline \multicolumn{8}{|c|}{ Dependent Variable: Years of schooling, individuals 19-28 years old in 1991} \\
\hline $\mathrm{I}[\mathrm{x}>0]$ & $\begin{array}{l}-0.014 \\
(0.347)\end{array}$ & $\begin{array}{c}0.031 \\
(0.201)\end{array}$ & $\begin{array}{c}0.207 \\
(0.280)\end{array}$ & $\begin{array}{c}0.132 \\
(0.150)\end{array}$ & $\begin{array}{c}0.160 \\
(0.245)\end{array}$ & $\begin{array}{c}0.114 \\
(0.131)\end{array}$ & $\begin{array}{c}0.125 \\
(0.161)\end{array}$ \\
\hline Observations & 114 & 111 & 163 & 160 & 217 & 213 & 695 \\
\hline R-squared & 0.43 & 0.80 & 0.40 & 0.80 & 0.29 & 0.78 & 0.76 \\
\hline \multicolumn{8}{|c|}{ Dependent Variable: Literacy, individuals 19-28 years old in 1991} \\
\hline $\mathrm{I}[\mathrm{x}>0]$ & $\begin{array}{c}0.030 \\
(0.023)\end{array}$ & $\begin{array}{c}0.031 * * * \\
(0.011)\end{array}$ & $\begin{array}{c}0.027 \\
(0.019)\end{array}$ & $\begin{array}{c}0.023 * * * \\
(0.008)\end{array}$ & $\begin{array}{c}0.018 \\
(0.017)\end{array}$ & $\begin{array}{c}0.016^{* *} \\
(0.008)\end{array}$ & $\begin{array}{c}0.024 * * * \\
(0.008)\end{array}$ \\
\hline Observations & 114 & 111 & 163 & 160 & 217 & 213 & 695 \\
\hline R-squared & 0.48 & 0.90 & 0.41 & 0.87 & 0.33 & 0.83 & 0.80 \\
\hline
\end{tabular}

$\underline{\text { Panel B: northern counties (North and Northeast regions) }}$

Dependent Variable: Years of schooling, individuals 19-28 years old in 1991

$\begin{array}{lccccccc}\mathrm{I}[\mathrm{x}>0] & 0.813 & 0.766^{*} & 0.750^{* *} & 0.446^{*} & 1.075^{* * *} & 0.420^{* *} & 0.512 * * \\ & (0.529) & (0.393) & (0.356) & (0.241) & (0.286) & (0.182) & (0.215) \\ \text { Observations } & 86 & 86 & 130 & 130 & 169 & 169 & 548 \\ \text { R-squared } & 0.54 & 0.85 & 0.50 & 0.78 & 0.39 & 0.75 & 0.69\end{array}$

Dependent Variable: Literacy, individuals 19-28 years old in 1991

\begin{tabular}{lccccccc}
$\mathrm{I}[\mathrm{x}>0]$ & 0.079 & 0.070 & $0.093^{* *}$ & $0.072^{* *}$ & $0.114^{* * *}$ & $0.054^{*}$ & $0.059^{* *}$ \\
& $(0.069)$ & $(0.047)$ & $(0.045)$ & $(0.035)$ & $(0.037)$ & $(0.027)$ & $(0.030)$ \\
Observations & 86 & 86 & 130 & 130 & 169 & 169 & 548 \\
R-squared & 0.53 & 0.81 & 0.53 & 0.77 & 0.48 & 0.76 & 0.66 \\
& & & & & & & \\
\hline
\end{tabular}

Notes: heteroskedasticity robust standard errors in parentheses. Neighborhood (\%) is \% distance from respective cutoff. Pre-treatment covariates (1980 census) include county income per capita, average years of schooling for individuals 25 years and older, poverty headcount ratio, illiterate percentage of over 15 year olds infant mortality, enrollment of 7 to 14 year olds and percent of population living in urban areas. All specifications allow for differential slopes and curvature by segment and relative to the thresholds. 
Table V: effects on schools and teacher-student ratios in urban vs. rural counties

\begin{tabular}{lccccccc}
\hline Specification: & Linear & Linear & Linear & Linear & Linear & Linear & Quartic \\
Neighborhood $(\%)$ & 2 & 2 & 3 & 3 & 4 & 4 & 15 \\
$\begin{array}{l}\text { Pre-treatment } \\
\text { Covariates: }\end{array}$ & $\mathrm{N}$ & $\mathrm{Y}$ & $\mathrm{N}$ & $\mathrm{Y}$ & $\mathrm{N}$ & $\mathrm{Y}$ & $\mathrm{Y}$
\end{tabular}

$\underline{\text { Panel A: urban counties (\% urban residents in } 1980>24.8 \text { ) }}$

Dependent Variable: number of municipal elementary schools

$\begin{array}{lccccccc}\mathrm{I}[\mathrm{x}>0] & -8.330 & -10.765 & -9.701^{*} & -4.363 & -8.225^{* *} & -4.964 & -5.895 \\ & (8.162) & (8.255) & (5.461) & (5.919) & (3.944) & (4.497) & (5.127) \\ \text { Observations } & 80 & 77 & 116 & 113 & 152 & 148 & 486 \\ \text { R-squared } & 0.73 & 0.78 & 0.71 & 0.74 & 0.76 & 0.79 & 0.65\end{array}$

Dependent Variable: primary school teacher-student ratio in 1991

$\begin{array}{lccccccc}\mathrm{I}[\mathrm{x}>0] & -0.000 & 0.001 & 0.004 & 0.002 & 0.001 & -0.005 & 0.008 \\ & (0.018) & (0.017) & (0.010) & (0.011) & (0.009) & (0.010) & (0.010) \\ \text { Observations } & 80 & 77 & 116 & 113 & 152 & 148 & 485 \\ \text { R-squared } & 0.59 & 0.72 & 0.56 & 0.68 & 0.52 & 0.58 & 0.46\end{array}$

$\underline{\text { Panel B: rural counties (\% urban residents in } 1980<24.8 \text { ) }}$

Dependent Variable: number of municipal elementary schools

$\begin{array}{lccccccc}\mathrm{I}[\mathrm{x}>0] & 21.317 & 21.194 & 4.701 & 4.425 & -0.505 & -0.247 & 8.273 \\ & (14.429) & (13.110) & (8.969) & (7.886) & (6.724) & (5.898) & (7.323) \\ \text { Observations } & 93 & 93 & 143 & 143 & 188 & 188 & 614 \\ \text { R-squared } & 0.67 & 0.77 & 0.62 & 0.72 & 0.62 & 0.71 & 0.58\end{array}$

Dependent Variable: primary school teacher-student ratio in 1991

\begin{tabular}{lccccccc}
$\mathrm{I}[\mathrm{x}>0]$ & $0.020 * * *$ & $0.019 *$ & $0.012^{* *}$ & 0.008 & $0.011^{* *}$ & $0.010^{* * *}$ & $0.015^{* * *}$ \\
& $(0.007)$ & $(0.011)$ & $(0.005)$ & $(0.005)$ & $(0.004)$ & $(0.004)$ & $(0.004)$ \\
Observations & 93 & 93 & 143 & 143 & 188 & 188 & 613 \\
R-squared & 0.77 & 0.81 & 0.70 & 0.74 & 0.67 & 0.70 & 0.61 \\
& & & & & & & \\
\hline
\end{tabular}

Notes: heteroskedasticity robust standard errors in parentheses. Neighborhood (\%) is \% distance from respective cutoff. Pre-treatment covariates (1980 census) include county income per capita, average years of schooling for individuals 25 years and older, poverty headcount ratio, illiterate percentage of over 15 year olds, infant mortality, enrollment of 7 to 14 year olds and percent of population living in urban areas. All specifications allow for differential slopes and curvature by segment and relative to the thresholds. 
Table VI: effects on schooling and literacy in urban vs. rural counties

\begin{tabular}{|c|c|c|c|c|c|c|c|}
\hline Specification: & Linear & Linear & Linear & Linear & Linear & Linear & Quartic \\
\hline Neighborhood (\%): & 2 & 2 & 3 & 3 & 4 & 4 & 15 \\
\hline $\begin{array}{l}\text { Pre-treatment } \\
\text { Covariates: }\end{array}$ & $\mathrm{N}$ & $\mathrm{Y}$ & $\mathrm{N}$ & $\mathrm{Y}$ & $\mathrm{N}$ & $\mathrm{Y}$ & Y \\
\hline
\end{tabular}

Panel A: urban counties (\% urban residents in $1980>24.8$ )

Dependent Variable: Years of schooling, individuals 19-28 years old in 1991

$\begin{array}{lccccccc}\mathrm{I}[\mathrm{x}>0] & -0.050 & 0.047 & 0.342 & 0.119 & 0.344 & 0.039 & 0.084 \\ & (0.376) & (0.239) & (0.342) & (0.209) & (0.281) & (0.175) & (0.179) \\ \text { Observations } & 105 & 102 & 146 & 143 & 193 & 189 & 609 \\ \text { R-squared } & 0.76 & 0.91 & 0.75 & 0.89 & 0.73 & 0.88 & 0.87\end{array}$

Dependent Variable: Literacy, individuals 19-28 years old in 1991

$\begin{array}{lccccccc}\mathrm{I}[\mathrm{x}>0] & 0.028 & 0.028 & 0.062 * * & 0.038^{* * *} & 0.068 * * * & 0.036^{* * *} & 0.040^{* * *} \\ & (0.028) & (0.017) & (0.025) & (0.013) & (0.022) & (0.014) & (0.014) \\ \text { Observations } & 105 & 102 & 146 & 143 & 193 & 189 & 609 \\ \text { R-squared } & 0.90 & 0.96 & 0.89 & 0.96 & 0.88 & 0.95 & 0.92\end{array}$

Panel B: rural counties (\% urban residents in $1980<24.8)$

Dependent Variable: Years of schooling, individuals 19-28 years old in 1991

$\begin{array}{lccccccc}\mathrm{I}[\mathrm{x}>0] & 0.585 & 0.760 & 0.541 & 0.442 & 0.721 * * * & 0.451 * * & 0.500^{* *} \\ & (0.568) & (0.495) & (0.374) & (0.282) & (0.275) & (0.192) & (0.221) \\ \text { Observations } & 95 & 95 & 147 & 147 & 193 & 193 & 634 \\ \text { R-squared } & 0.81 & 0.93 & 0.82 & 0.92 & 0.79 & 0.91 & 0.88\end{array}$

Dependent Variable: Literacy, individuals 19-28 years old in 1991

\begin{tabular}{lccccccc}
$\mathrm{I}[\mathrm{x}>0]$ & 0.043 & 0.064 & 0.044 & 0.055 & $0.059 *$ & $0.042 *$ & $0.056^{* *}$ \\
& $(0.072)$ & $(0.061)$ & $(0.042)$ & $(0.036)$ & $(0.031)$ & $(0.024)$ & $(0.025)$ \\
Observations & 95 & 95 & 147 & 147 & 193 & 193 & 634 \\
R-squared & 0.84 & 0.95 & 0.86 & 0.94 & 0.85 & 0.93 & 0.88 \\
\hline
\end{tabular}

Notes: heteroskedasticity robust standard errors in parentheses. Neighborhood (\%) is \% distance from respective cutoff. Pre-treatment covariates (1980 census) include county income per capita, average years of schooling for individuals 25 years and older, poverty headcount ratio, illiterate percentage of over 15 year olds, infant mortality, enrollment of 7 to 14 year olds and percent of population living in urban areas. All specifications allow for differential slopes and curvature by segment and relative to the thresholds. 
Table VII: First stage and IV estimates: North, South, Rural and Urban counties

$\begin{array}{llll}\text { Sample } & \text { Full North South }\end{array}$

Dependent Variable: Per capita FPM transfer 1982-1990, 2005 Reais ('000)

$\begin{array}{lccccc}\text { Pooled Thresholds 1-3 } & & & & & \\ \text { I[x }>0] & 0.728 * * * & 0.821 * * * & 0.725 * * * & 0.939 * * * & 0.733 * * * \\ & (0.162) & (0.215) & (0.224) & (0.257) & (0.220) \\ \text { Observations } & 358 & 152 & 206 & 173 & 185 \\ \text { R-squared } & 0.29 & 0.38 & 0.26 & 0.39 & 0.36 \\ & & & & & \\ \text { Pooled Thresholds 1-2 } & & & & & \\ \text { I[x }>0] & 0.811^{* * *} & 0.889 * * * & 0.843^{* * *} & 1.118^{* * *} & 0.790 * * * \\ & (0.183) & (0.234) & (0.248) & (0.257) & (0.262) \\ \text { Observations } & 293 & 125 & 168 & 143 & 150 \\ \text { R-squared } & 0.33 & 0.46 & 0.28 & 0.42 & 0.45\end{array}$

Dependent Variable: Years of schooling, individuals 19-28 years old in 1991

$\begin{array}{lccccc}\text { Pooled Thresholds 1-3 } & & & & & \\ \text { Per capita FPM ('000) } & 0.416^{* *} & 0.510^{* *} & 0.138 & 0.572^{* *} & 0.225 \\ & (0.168) & (0.239) & (0.173) & (0.232) & (0.192) \\ \text { Observations } & 358 & 152 & 206 & 173 & 185 \\ \text { R-squared } & 0.83 & 0.58 & 0.74 & 0.80 & 0.82 \\ & & & & & \\ \text { Pooled Thresholds 1-2 } & & & & & \\ \text { Per capita FPM ('000) } & 0.425 * * & 0.464^{*} & 0.106 & 0.558^{* *} & 0.290 \\ & (0.202) & (0.238) & (0.207) & (0.238) & (0.293) \\ \text { Observations } & 293 & 125 & 168 & 143 & 150 \\ \text { R-squared } & 0.84 & 0.63 & 0.74 & 0.80 & 0.82\end{array}$

Dependent Variable: Literacy, individuals 19-28 years old in 1991

$\begin{array}{lccccc}\text { Pooled Thresholds 1-3 } & & & & & \\ \text { Per capita FPM ('000) } & 0.056^{* * *} & 0.077^{* *} & 0.023^{*} & 0.048^{*} & 0.056^{* *} \\ & (0.018) & (0.033) & (0.013) & (0.025) & (0.022) \\ \text { Observations } & 358 & 152 & 206 & 173 & 185 \\ \text { R-squared } & 0.85 & 0.56 & 0.71 & 0.87 & 0.84 \\ & & & & & \\ \text { Pooled Thresholds 1-2 } & & & & & \\ \text { Per capita FPM ('000) } & 0.055^{* * *} & 0.083^{* *} & 0.016 & 0.038^{*} & 0.060^{*} \\ & (0.021) & (0.036) & (0.014) & (0.023) & (0.033) \\ \text { Observations } & 293 & 125 & 168 & 143 & 150 \\ \text { R-squared } & 0.86 & 0.60 & 0.75 & 0.89 & 0.85\end{array}$

Notes: heteroskedasticity robust standard errors in parentheses. Neighborhood is $+/-4 \%$ from respective cutoffs in all specifications. Pre-treatment covariates (1980 census) in all specifications include county income per capita, average years of schooling for individuals 25 years and older, poverty headcount ratio, illiterate percentage of over 15 year olds, infant mortality, enrollment of 7 to 14 year olds and percent of population living in urban areas. 